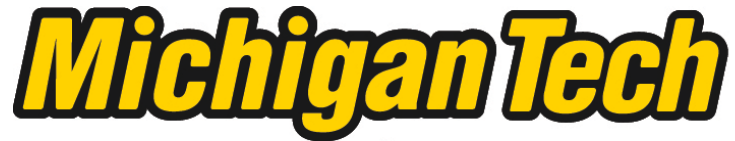 \\ Michigan Technological University Create the Future Digital Commons @ Michigan Tech
}

2014

\section{STATIC AND DYNAMIC STRESS CHANGE AT 27 VOLCANOES OF THE CENTRAL AMERICAN VOLCANIC ARC AFTER THE MW. 7.6 COSTA RICA EARTHQUAKE OF 5 SEPTEMBER 2012}

Lorenzo Gratton

Michigan Technological University

Follow this and additional works at: https://digitalcommons.mtu.edu/etds

Part of the Geology Commons, and the Geophysics and Seismology Commons Copyright 2014 Lorenzo Gratton

Recommended Citation

Gratton, Lorenzo, "STATIC AND DYNAMIC STRESS CHANGE AT 27 VOLCANOES OF THE CENTRAL AMERICAN VOLCANIC ARC AFTER THE MW. 7.6 COSTA RICA EARTHQUAKE OF 5 SEPTEMBER 2012", Master's Thesis, Michigan Technological University, 2014.

https://doi.org/10.37099/mtu.dc.etds/787

Follow this and additional works at: https://digitalcommons.mtu.edu/etds

Part of the Geology Commons, and the Geophysics and Seismology Commons 
STATIC AND DYNAMIC STRESS CHANGE AT 27 VOLCANOES OF THE CENTRAL AMERICAN VOLCANIC ARC AFTER THE MW. 7.6 COSTA RICA EARTHQUAKE OF 5 SEPTEMBER 2012.

By

Lorenzo Gratton

\begin{abstract}
A THESIS
Submitted in partial fulfillment of the requirements for the degree of MASTER OF SCIENCE

In Geology
\end{abstract}

MICHIGAN TECHNOLOGICAL UNIVERSITY

2014

(C) 2014 Lorenzo Gratton 
This thesis has been approved in partial fulfillment of the requirements for the Degree of MASTER OF SCIENCE in Geology.

Department of Geological and Mining Engineering and Sciences

Thesis Advisor: $\quad$ Dr. Gregory P. Waite

Committee Member: Dr. Simon Carn

Committee Member: Dr. Alessandro Tibaldi

Department Chair: John S. Gierke 


\section{Table of Contents}

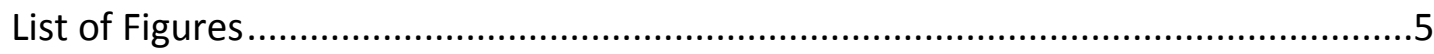

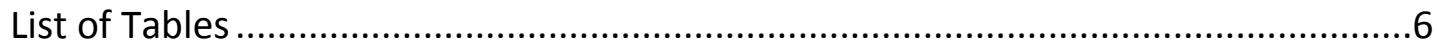

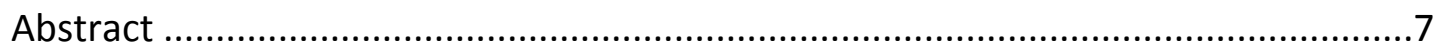

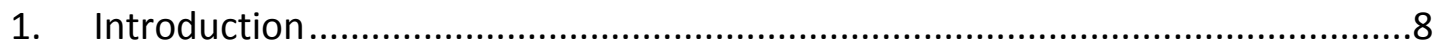

2. 5 September 2012 - Mw 7.6 Costa Rica Earthquake.....................................12

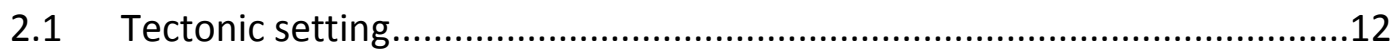

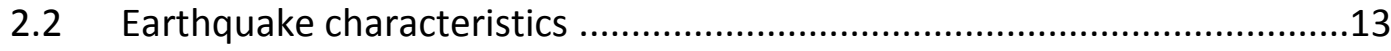

2.2.1 Earthquake description ..........................................................13

2.2.2 Finite fault model and directivity data ...........................................15

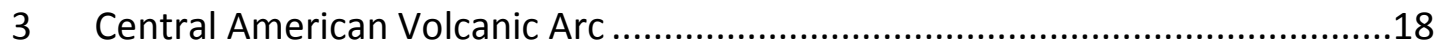

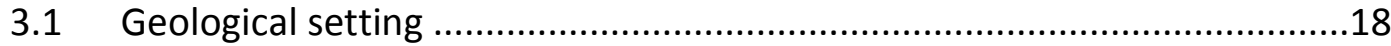

4. Volcanic activity following the earthquake ..............................................20

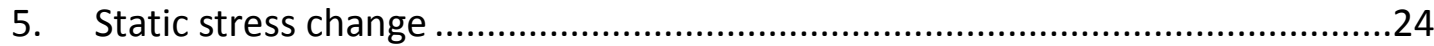

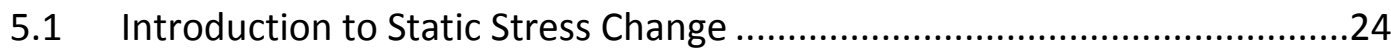

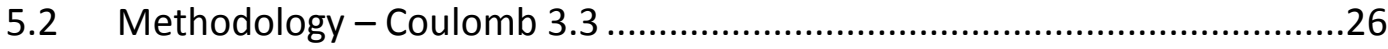

5.3 Results of the Static Stress Change Analysis .......................................29

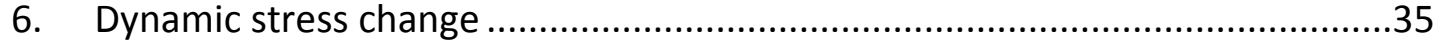

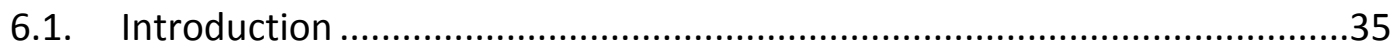

6.2. Use of dynamic stress change in the context of the work .........................36

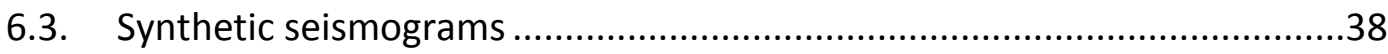

6.3.1. Finite fault effects (directivity) ….....................................................39

6.3.2. Synthetic seismogram testing …...............................................42

6.3.3. Synthetic seismograms for the 27 volcanoes..................................44

6.3.4. Synthetic seismograms from finite fault model ...............................46 


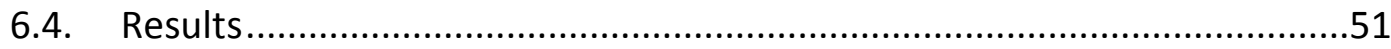

6.4.1. Single point source model .........................................................51

6.4.2. Finite-fault model results ...........................................................54

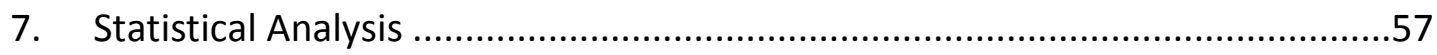

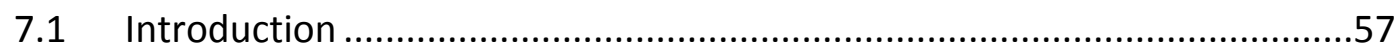

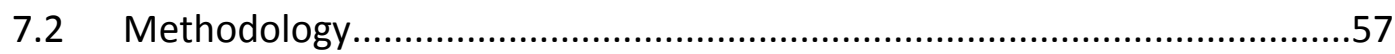

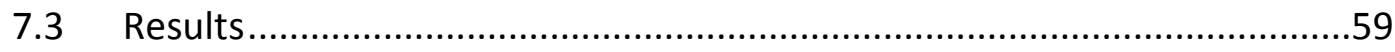

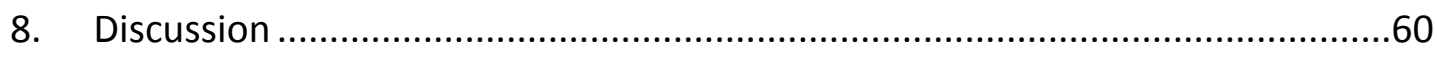

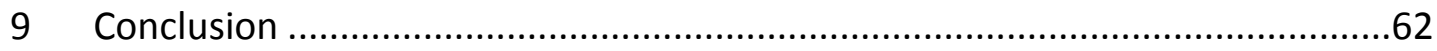

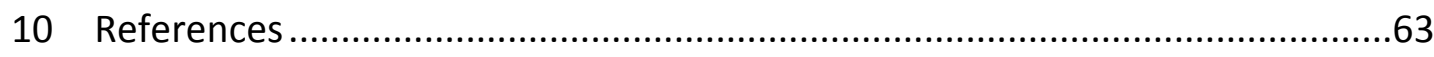

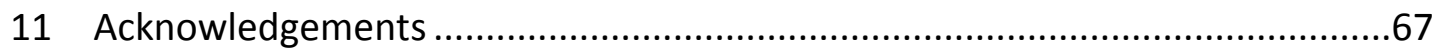

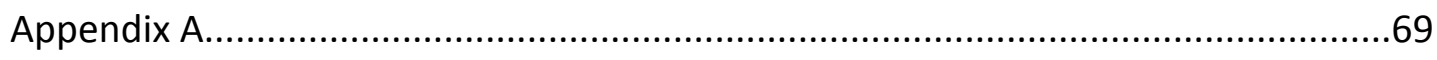

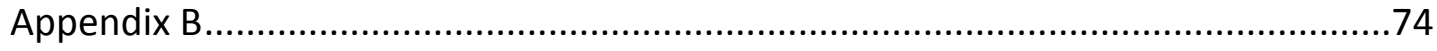

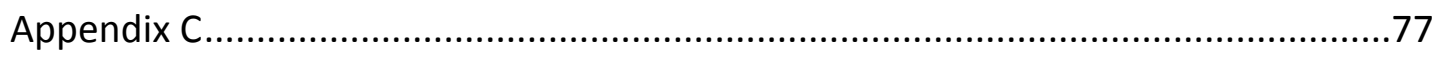

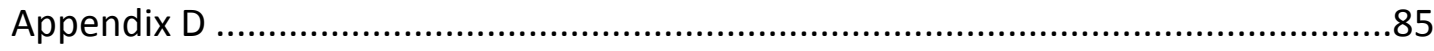

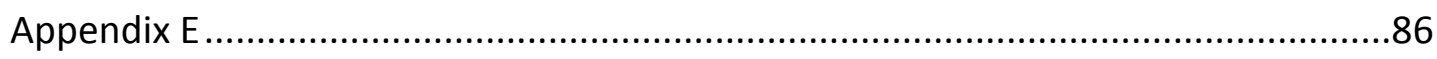

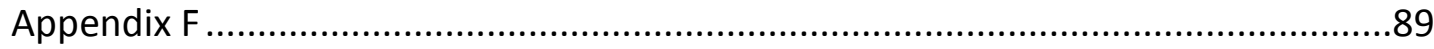

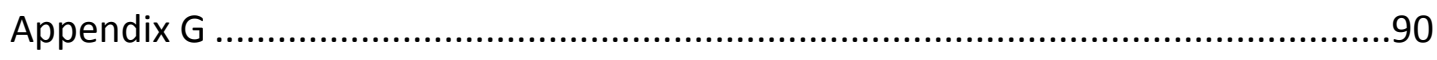

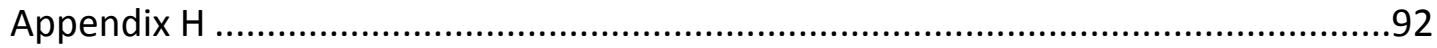




\section{List of Figures}

2.1 Map of earthquake epicenter and volcanoes..............................................12

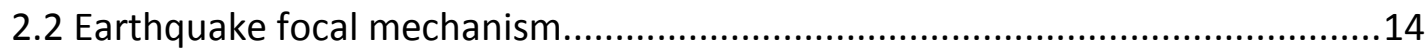

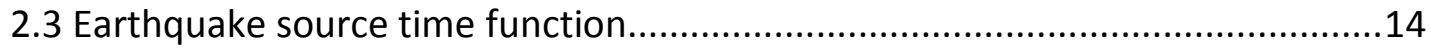

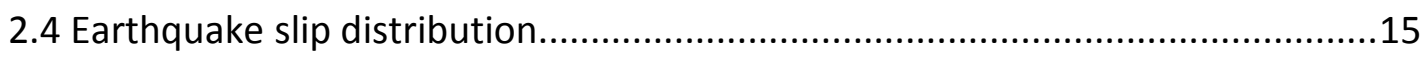

4.1 Number of micro-earthquakes at Arenal......................................................21

4.2 Number of micro-earthquakes at Rincon de la Vieja.....................................22

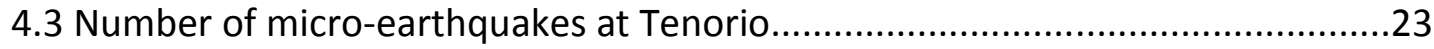

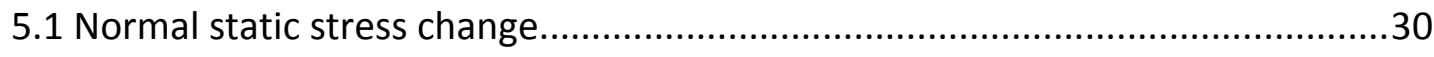

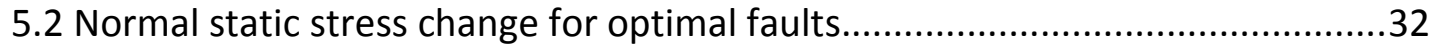

5.3 Static stress change, strike orientation map................................................3

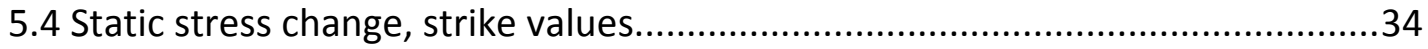

6.1 Directivity effect on seismograms...........................................................41

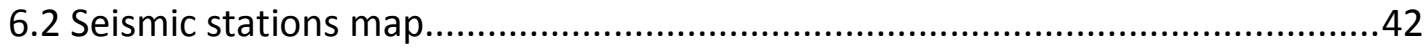

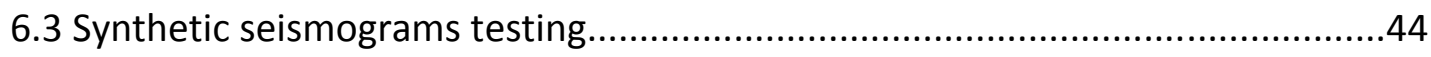

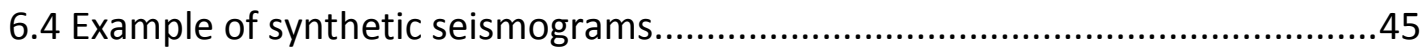

6.5 Example of Finite Fault Model Synthetic seismograms..................................48

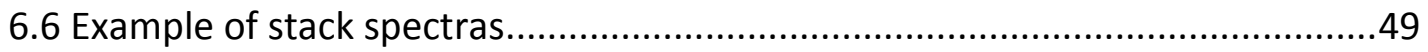

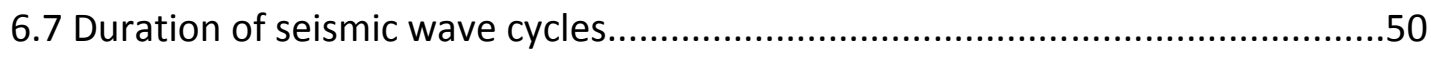

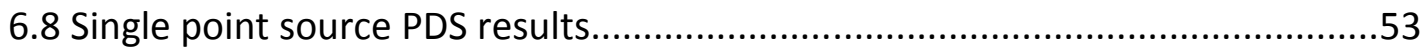

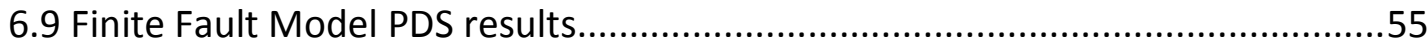




\section{List of Tables}

$2.1 \mathrm{M}_{\mathrm{w}} 7.6$ Costa Rica earthquake characteristics...........................................17

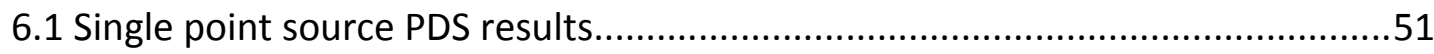

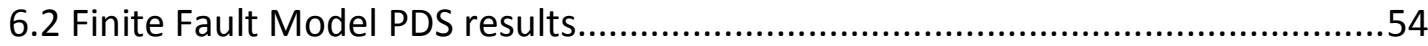

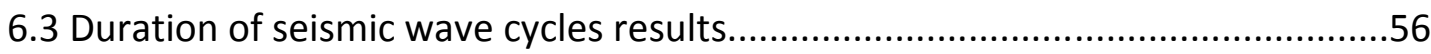

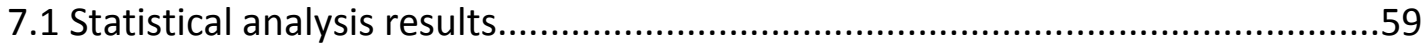

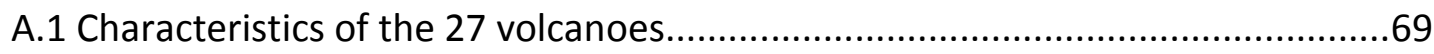

B.1 Signs of activity at the volcanoes following the earthquake.............................74

C.1 Obtained values of static stress change...................................................77

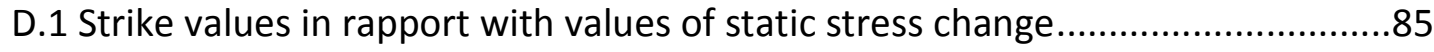

E.1 Obtained values of dynamic stress change, single point source........................86

F.1 Obtained values of dynamic stress change, finite fault model..........................89

G.1 Parameters used in the statistical analysis.................................................90 


\begin{abstract}
Large earthquakes may strongly influence the activity of volcanoes through static and dynamic processes. In this study, we quantify the static and dynamic stress change on 27 volcanoes in Central America, after the $M_{w} 7.6$ Costa Rica earthquake of 5 September 2012. Following this event, 8 volcanoes showed signs of activity. We calculated the static stress change due to the earthquake on hypothetical faults under these volcanoes with Coulomb 3.3. For the dynamic stress change, we computed synthetic seismograms to simulate the waveforms at these volcanoes. We then calculated the Peak Dynamic Stress (PDS) from the modeled peak ground velocities. The resulting values are from moderate to minor changes in stress $\left(10^{-1}\right.$ $10^{-2} \mathrm{MPa}$ ) with the PDS values generally an order of magnitude larger than the static stress change. Although these values are small, they may be enough to trigger a response by the volcanoes, and are on the order of stress changes implicated in many other studies of volcano and earthquake triggering by large earthquakes. This study provides insight into the poorly-constrained mechanism for remote triggering.
\end{abstract}




\section{Introduction}

Earthquakes have widely been recognized as capable of triggering volcanic eruptions. This was formerly just a supposition, which can be traced back to 1840, the year of a report by Charles Darwin on the eruption of two Chilean volcanoes (Darwin 1840, Manga and Bodsky 2006, Eggert and Walter 2009, Watt, Pyle et al.

2009). There is now mounting evidence from a large number of earthquake-volcanic eruption pairs, such as the eruptions of Cordón Caulle (Chile) 38 hours after the Mw9.5 Chile earthquake in 1960 and Santa Maria volcano (Guatemala) 6 months after the M7.5 1902 Guatemala earthquake, of the relationship between seismicity and volcanic activity (Hill, Pollitz et al. 2002, Manga and Bodsky 2006, Eggert and Walter 2009, Watt, Pyle et al. 2009).

Eruptions take place when the plumbing system of a volcano has reached a threshold pressure, either with slow accumulation or due to a sudden change of stress. It has been shown that earthquakes can sometimes provide changes of stress large enough to make the plumbing system reach this threshold and trigger an eruption (Manga and Bodsky 2006). To firm up this concept, many authors have statistically assessed the correlation between these two kinds of events: after examining historical records, they found that simple coincidence could not alone explain the immediate concurrence of many earthquakes and volcanic eruptions (Linde and Sacks 1998, Marzocchi 2002, Eggert and Walter 2009). The process of stress modifications, in the proximity of the volcano or in the volcanic plumbing system, can happen either in a static or in a dynamic way (Manga and Bodsky 2006, Watt, Pyle et al. 2009). Static stress changes depend on the permanent deformation of the Earth's crust due to the offset of a seismogenic fault. Their effects decay relatively quickly in space as they are inversely proportional to the cube of distance from the hypocenter. They are therefore considered to be effective only within the 
near field, at a distance of a few faults lengths from the earthquake's epicenter (Manga and Bodsky 2006). Dynamic stress changes, on the other hand, are a consequence of the seismic waves released by the earthquake itself and thus depend on many factors such as distance, directivity, structure of the crust, frequency content and radiation pattern. All these parameters influence the amplitude of shaking and the distance that the waves can reach, but dynamic stresses generally decay in space according to the following formula:

$$
x=r^{-1.66}
$$

where $x$ is a parameter representing the intensity of the effect (Manga and Brodsky, 2006).

It is clear that dynamic stress changes can reach much longer distances than the static ones, being thus more effective in stressing far field areas; their effect is however transitory so requires a subsequent mechanism to make the stress change permanent (Manga and Bodsky 2006).

Many authors have proposed different models in order to describe this process, whose importance and effectiveness is still widely discussed (Hill, Pollitz et al. 2002, Manga and Bodsky 2006, Watt, Pyle et al. 2009). The order of magnitude of the change in stress related to both static and dynamic processes is, however, usually in the order of $10^{-2}-10^{-1} \mathrm{MPa}$, and thus it's thought that the magmatic system of the volcano must be already in a critical state in order to erupt (Manga and Brodsky, 2006). For comparison ocean tides and solid earth tides provide change in stress in the order of $10^{-2}$ and $10^{-3} \mathrm{MPa}$, respectively (Manga and Brodsky, 2006). Changes in barometric pressure, which have also been implicated as triggers for changes in geyser activity, are on the order of $10^{-3} \mathrm{MPa}$ (Reinhart, 1972).

The aim of this project is to quantify the static and dynamic stress changes caused by the Mw. 7.6 Costa Rica earthquake of 5 September, 2012 on several active 
volcanoes and evaluate the possibility of a link between the earthquake and subsequent volcanic activity documented at a subset of these volcanoes. In order to do so, we analyzed 27 volcanoes along the Central American Volcanic Arc, which stretches along the Pacific Coast, from Mexico to Panama. In particular, we focused on the eight volcanoes (Arenal, Rincon de la Vieja, Poas, Turrialba, Apoyeque, Cerro Negro, Telica and San Cristobal) that showed volcanic activity immediately or shortly following the seismic event, suggesting a strong correlation between the two. This information was collected with the help of the Smithsonian Institution's Global Volcanism Program's weekly reports (http://www.volcano.si.edu), where we searched our volcanoes and saw which of them actually went through volcanic activity following the earthquake. The static stress change is analyzed with the program Coulomb 3.3 (Toda S. et al., 2005; Lin J. and Stein R.S., 2004) which, starting from the displacement of the seismogenic fault computes the stress changes at a given location at a given receiver fault. The results are the positive or negative amounts of shear stress change, normal stress change and Coulomb stress change, given in bars. For this work, we focus our attention on the normal stress change affecting hypothetical normal faults of various strike orientations situated at three kilometers of depth under every volcano. These simulate feeding systems, which could bring fresh magma to the surface. These results are then analyzed and discussed, as they are useful from the point of view of this research.

For the dynamic stress change calculations, synthetic seismograms are computed for hypothetical receivers at each of the volcanoes. The program used, Computer Programs in Seismology 3.3, or CPS by R.B. Herrmann (2003), needs several inputs: an Earth model, the descriptions of the receiving pseudo-seismometers' characteristics and the information about the source mechanism. This information is used to calculate synthetic seismograms. The program gives as output a three- 
component time history of ground velocity due to a particular earthquake source mechanism. We thus computed synthetic seismograms for all the 27 volcanoes treating the earthquake as a single point source, we then focused on those eight volcanoes which showed signs of activity and computed other synthetic seismograms, starting this time from the earthquake finite fault model. From these outputs we are able to assess the effective dynamic stress changes experienced by the volcanoes and thus to make considerations and hypothesis on their role in causing the volcanic activity.

This project thus provides insights on the possible correlation between earthquake events and following volcanic activity. While there is mounting evidence for triggering of volcanic eruptions from large earthquakes (Hill, Pollitz et al. 2002, Manga and Bodsky 2006, Eggert and Walter 2009, Watt, Pyle et al. 2009), there is still significant uncertainty about the mechanisms involved. To find out how this process works and develops would be very beneficial in the field of volcanic hazard management, in that it would allow to government and non-government organizations to be aware of this real connection between the two phenomena and to promptly focus their actions where they are needed. This project aims to increase and further develop our understanding on this complicated subject. 


\section{5 September 2012 - Mw 7.6 Costa Rica Earthquake}

\section{$2.1 \quad$ Tectonic setting}

The $M_{w} 7.6$ earthquake of 5 September, 2012 took place below the Nicoya peninsula, in Costa Rica. This Central American country is located on the western part of the Caribbean plate, below which the Cocos plate subducts along the Middle American Trench. The subduction rates range from 70 to $94 \mathrm{~mm}$ per year (Protti et al., 1995) and studies have shown that there is a strong coupling between the two plates under the Nicoya peninsula, probably due to bathymetric features of the subducting oceanic floor (Protti et al., 1995). This is translated in a potential to produce earthquakes of significant magnitude, as has already happened in 1853, 1900, 1950 and 1990 with events with $M_{w} \geq 7$ (Protti et al., 1995; Dixon, 2013). The subduction of the Cocos plate gives rise to the Central American Volcanic Arc. This mountain chain, to which all the volcanoes analyzed in this project belong (with the exception of Volcano Azul), runs parallel to the trench and stretches from Mexico to Panama (Fig 2.1)(Rose et al., 1999).

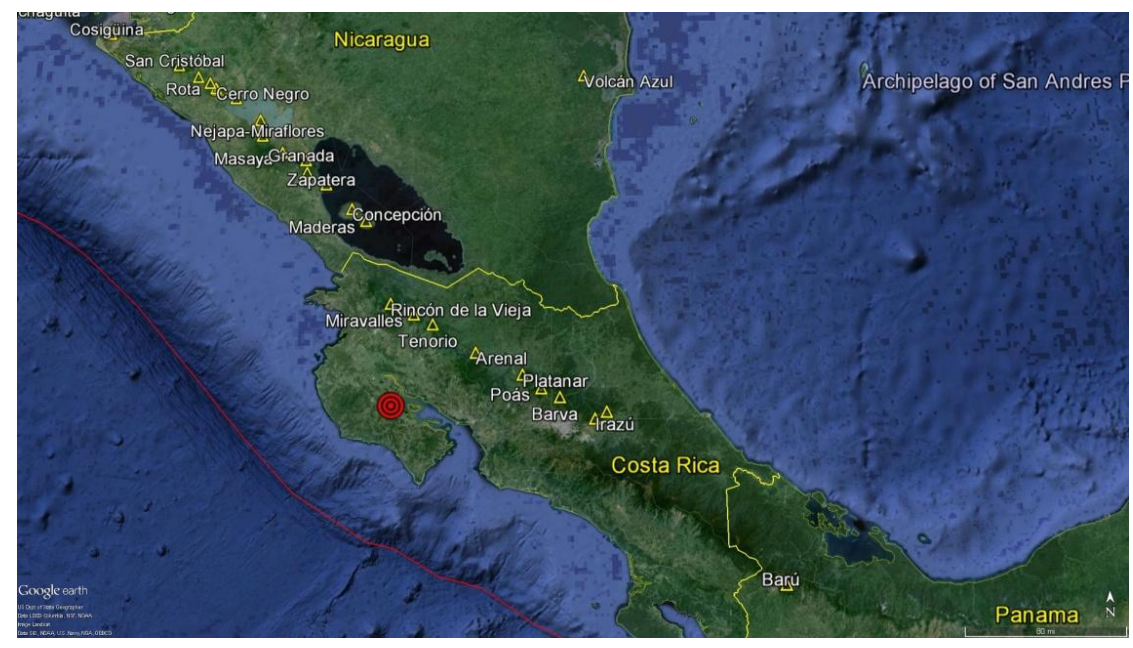


Figure 2.1 - Map showing the epicenter of the Mw 7.6 earthquake (red circles), part of the Central American Volcanic Arc (yellow triangles) and the Middle American Trench (red line). Map Data: Google, SIO, NOAA, U.S. Navy, NGA, GEBCO. See Appendix H for documentation of permission to republish this material.

\subsection{Earthquake characteristics}

\subsubsection{Earthquake description}

The USGS located the epicenter of this earthquakeat $10.086^{\circ} \mathrm{N}$ and $85.305^{\circ} \mathrm{W}$, with an origin time of 14:42:08 UTC 5 September, 2012

(http://comcat.cr.usgs.gov/earthquakes/eventpage/pde20120905144207800_35\#s

ummary). Its hypocenter, the point at which the rupture began, has been calculated around 35 kilometers depth. The USGS reported that the earthquake had been widely felt throughout Central America, from Guatemala City to Panama, several hundreds of kilometers either side of the epicenter. While there have been reports from many local and international newspapers of damaged buildings, people evacuated and general panic, the earthquake directly claimed only one victim. From its focal mechanism (Fig. 2.2) we can identify the event as a megathrust earthquake, produced by a reverse fault and directly related to the subduction of the Cocos plate. The duration of the earthquake was approximately 60 seconds, though the source time function (Fig. 2.3) shows that most of its energy was released in the first 20 seconds of the event. A finite-fault model, described below, released by the USGS has a fault length of about $147 \mathrm{~km}$, although the majority of the slip (200-300 $\mathrm{cm}$ ) was within a radius of about 30 kilometers from the hypocenter (Fig. 2.4)( http://comcat.cr.usgs.gov/earthquakes/eventpage/pde20120905144207800_35). 


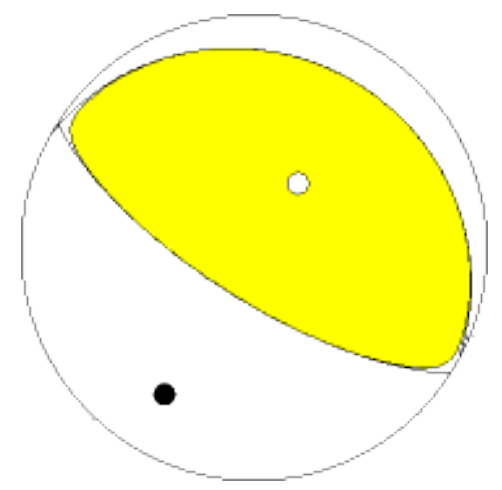

Figure 2.2 - Focal mechanism of the Mw 7.6 Costa Rica earthquake. Image courtesy of the U.S. Geological Survey, available at (http://earthquake.usgs.gov/earthquakes/eqinthenews/2012/usc000cfsd/neic_c000cfsd_cmt.php). See Appendix $\mathrm{H}$ for documentation of permission to republish this material.

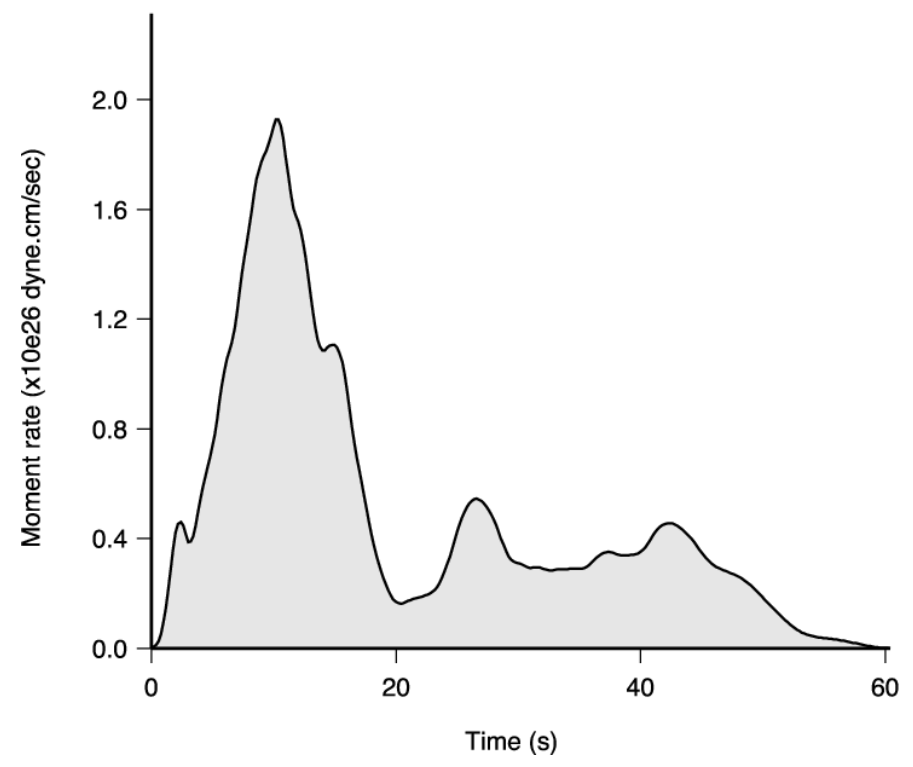

Figure 2.3 - Source time function of the Mw 7.6 Costa Rica earthquake. Image courtesy of the U.S. Geological Survey, available at (http://earthquake.usgs.gov/earthquakes/eqinthenews/2012/usc000cfsd/finite_fault.php). See Appendix $\mathrm{H}$ for documentation of permission to republish this material. 


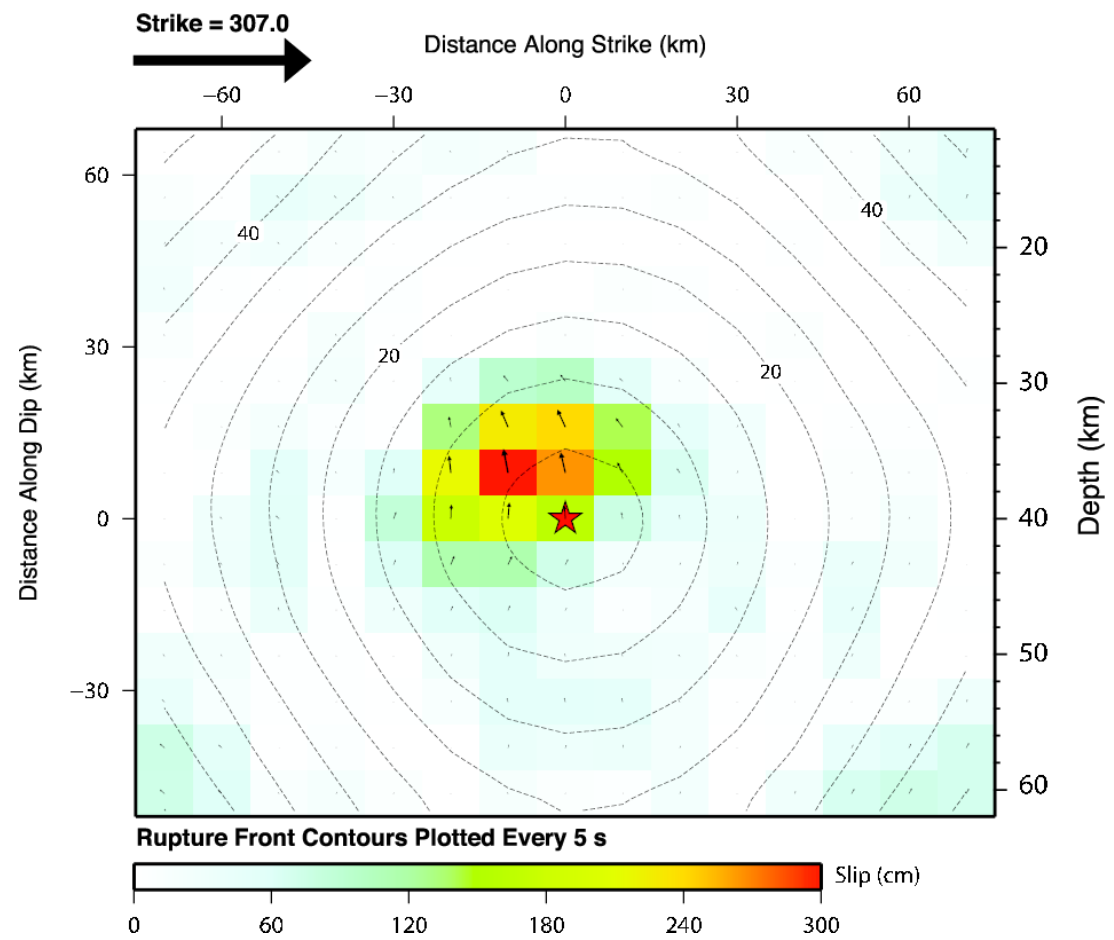

Figure 2.4 - Cross section of slip distribution of the Mw 7.6 Costa Rica earthquake. The contours represent positions in space and time of the rupture front. Image courtesy of the U.S. Geological Survey, available at (http://earthquake.usgs.gov/earthquakes/eqinthenews/2012/usc000cfsd/finite_fault.php). See Appendix $\mathrm{H}$ for documentation of permission to republish this material.

\subsubsection{Finite fault model and directivity data}

A fault's finite extent, compared to a single point source, is a more realistic model for earthquakes and is especially important for large events. While the point-source model considers that all the energy of a given earthquake is released from a single point source (the hypocenter), a finite-fault model is a step closer to what actually happens in nature. In this latter model, slip is distributed over space and time. Typically, the earthquake fault is subdivided into many sub-faults, which may be of the same size or not, each with their own values of rake, dip, slip amount, slip time 
history and thus, magnitude (Motazedian and Atkinson, 2005). In this way, each sub-fault is treated as a different point source and its effect can be later summed to that of others at the observation point, taking into account the proper time delay (Motazedian and Atkinson, 2005). Since the sub-faults are not expected to start to slip all at the same time and the amount and the duration of slip is different, a net effect called directivity can become significant. In a given earthquake, slip begins at the hypocenter and propagates away from that point. The direction of the propagation of the rupture front may or may not coincide with the direction of slip. In the direction of rupture propagation, the energy of this earthquake will thus pile up. This process is referred to as directivity (Somerville, 2003). This is due to the similar velocities that characterize the physical rupturing process of the fault, and the propagation of the shear waves originated at different points. For shear waves that propagate in the same direction as the fault rupture, the final result is that the energy of the shear waves amplify (Somerville, 2003). A given location can thus experience forward or backward directivity depending on whether the fault is rupturing toward or away from it. In the first case, the amplitude of the seismic waves will be greatly increased. At the same time, the duration is reduced and the frequency is increased. Backward directivity, on the contrary, reduces the waves' amplitude and enhances their duration and period (Sommerville, 2003). Directivity has a well fitting analogy in the more-known Doppler effect, where sound waves are perceived differently if their source is moving toward or away from the listener. As with directivity, in the first case the sound waves will be characterized by higher frequencies and a higher pitch. In the latter, waves will be more spread out, the frequency will be lower and the sound more dispersed. Finally, a fault can rupture unilaterally or bilaterally, respectively if there is either only one or two fronts of rupture propagation. Ground motion at any given site, particularly in the areas closer to the fault, may be strongly influenced by this mechanism, and thus, when 
possible, it is important to take this into account (Bray and Rodriguez-Marek, 2004). This can only be done using finite fault models. The USGS issued two finite-fault models for this earthquake, one comprised of 225 sub-faults (Table 2.1) and the other 80 . We used the former to calculate the static stress change at our volcanoes, while we used the latter when working on the finite fault model dynamic stress change. Although the final result is somewhat dependent on the number of subfaults used in the process (Motazedian and Atkinson, 2005), we decided to use the 80 -patches model to speed up the process of actually computing the waveforms when accounting for directivity, as well as to address processing limitations when calculating the synthetic seismograms.

Table 2.1 - Characteristics for the Mw 7.6 Costa Rica earthquake 225 patches finite fault model, taken from the USGS Coulomb 3.3 input file.

\begin{tabular}{|c|c|}
\hline Earthquake name & Costa Rica \\
\hline $\begin{array}{c}\text { Epicenter coordinates } \\
\left(\text { lat/lon, }{ }^{\circ}\right)\end{array}$ & $10,086 /-85,305$ \\
\hline Date (dd/mm/year) & 05/09/2012 \\
\hline UTC time & $14: 42: 08$ \\
\hline $\mathrm{M}_{\mathrm{w}}$ & 7,6 \\
\hline Rupture length (km) & 147 \\
\hline $\begin{array}{c}\text { Fault geometry } \\
\text { (strike/dip, }{ }^{\circ} \text { ) }\end{array}$ & 317 / 19 \\
\hline N. of patches & 225 \\
\hline Average slip (m) & 0,28 \\
\hline Average rake angle $\left({ }^{\circ}\right)$ & 97,6 \\
\hline Fault top $(\mathrm{km})$ & 11,26 \\
\hline Fault bottom (km) & 61,97 \\
\hline $\begin{array}{c}\text { Regional } \sigma_{1} \\
\left(\text { azimuth,/plunge, }{ }^{\circ} \text { ) }\right.\end{array}$ & $19 / 0$ \\
\hline $\begin{array}{c}\text { Regional } \sigma_{2} \\
\left(\text { azimuth,/plunge, }{ }^{\circ} \text { ) }\right.\end{array}$ & $90 / 90$ \\
\hline $\begin{array}{c}\text { Regional } \sigma_{3} \\
\left(\text { azimuth,/plunge, }{ }^{\circ} \text { ) }\right.\end{array}$ & $109 / 0$ \\
\hline
\end{tabular}




\section{Central American Volcanic Arc}

\subsection{Geological setting}

All the volcanoes taken into consideration for this thesis are located in Nicaragua, Costa Rica and Panama and they belong (with the exception of Volcan Azul) to the Central American Volcanic Arc (CAVA). This latter is a tectonically active feature which stretches from the south of Mexico to Panama, extending for more than 1500 kilometers roughly parallel to the strike of the Middle American Trench (Rose et al., 1999; Stoiber and Carr, 1973; Carr et al., 2003; Leeman et al., 1993 and reference therein). The modern arc is composed of around 50 main volcanic edifices and many other minor centers which make up the main volcanic front. Behind this, many authors (Stoiber and Carr, 1973; Carr et al., 2003; Leeman et al., 1993 and reference therein) recognize the existence of smaller and more weakly aligned clusters of volcanic features. The volcanoes are generally continuous throughout the arc, with the exception of a 175-kilometer gap between Turrialba and Irazù volcanoes in central Costa Rica and Barù volcano in northern Panama (Leeman et al., 1993 and reference therein). The change of the average strike between different parts of the arc was used to distinguish eight sections of the volcanic chain. Carr and colleagues (Stoiber and Carr, 1973; Carr et al., 2003) explained these different orientations subdividing the subducting Cocos plate in eight different parts as well, each one of them with a slightly different value of dip. However, more recent work shows that the dip of the down-going Cocos plate is laterally constant, with an average value of $60^{\circ}$, and it gets shallower only in central Costa Rica and Panama where there is the subduction of the Cocos Ridge (Leeman et al., 1993 and reference therein). The volcanic arc is also accompanied by many major parallel 
structures, mainly normal faults and horst and graben features, which reveal an extensional tectonic regime, in contrast with the compressional one characterizing the trench (Stoiber and Carr, 1973). The basement rocks underling the volcanic chain vary from metamorphic, marine and non-marine sedimentary rocks and oceanic and arc crust fragments, and are characterized by very different ages, which ranges from late Paleozoic to Neogene (Leeman et al., 1993 and reference therein). This latter fact may be somewhat related to the equally big variety in the petrogenetic characteristics of the volcanic products, which range from rhyolite to andesite and basalt (Stoiber and Carr, 1973; Leeman et al., 1993 and reference therein). All the quaternary volcanism in this long section is in any case related to the subduction of the Cocos plate and the remaining part of the Nazca plate under the Caribbean plate. Their convergence rates vary according to authors, ranging between 94 and $60 \mathrm{~mm} / \mathrm{yr}$ for the Cocos plate and being around $54 \mathrm{~mm} / \mathrm{yr}$ for the Nazca one (Protti et al., 1995; Leeman et al., 1993 and reference therein).

In Appendix A are listed, from north to south, the 27 volcanoes we worked with during this project. Different parameters are listed for all of them, among these, the distance and azimuth from the $M_{w} 7.6$ Nicoya peninsula earthquake of 5 September 2012. 


\section{Volcanic activity following the earthquake}

Following the $M_{w} 7.6$ Nicoya earthquake, at least ten volcanoes among the 27 in our study showed some kind of activity. All the information here presented has been taken from the Weekly Reports of the Smithsonian Institution Global Volcanism Program (http://www.volcano.si.edu/), unless otherwise noted, and are current as of 15 May 2014. The volcanoes that showed any signs of activity following the earthquake are, in order of increasing distance from the epicenter: Arenal, Rincón de la Vieja, Poás, Irazú, Turrialba, Apoyeque, Tenorio, Cerro Negro, Telica, and San Cristóbal. Here follows a brief description of their possibly induced activity.

Arenal was reported to have hydrothermal activity and tremor during the early days of September, 2013. Rising plumes of water vapor were also recorded on 8 September 2013. The latest activity before the earthquake dates back to August 2011 and was characterized by rising plumes. There was an increase in seismicity in the vicinity of the volcano as well, with an increase of nearly 10 times the average of the eight months leading up to September (Fig. 4.1)(Waldo Taylor, personal communication, 2014). The number of earthquake dropped after September. 


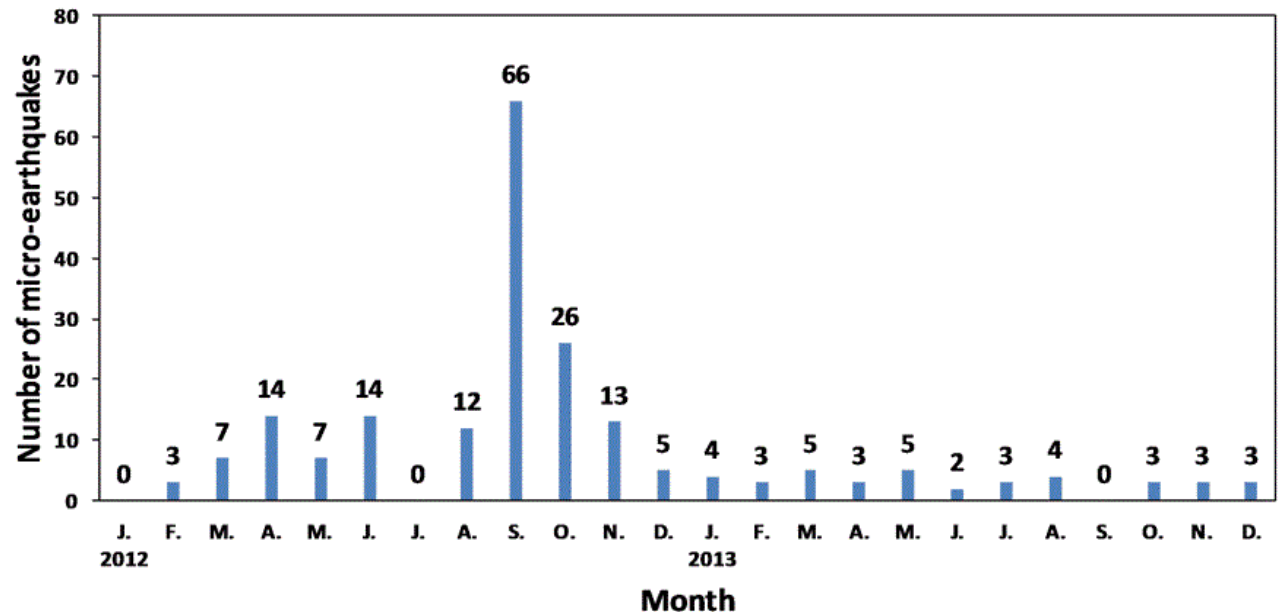

Figure 4.1 - Number of earthquakes each month of 2012 and 2013 at Arenal and proximity. Data from the National Seismic Natwork of Costa Rica (RSN) run by the University of Costa Rica (UCR) and the national electric company (ICE).

Rincón de la Vieja was reported to have white rising plumes from its active crater on 26 February 2013. Cloudy weather made it impossible to directly observe the crater, however the report says that the visible parts of the volcano showed no other signs of activity. The latest activity, a phreatic eruption, before the $M_{w} 7.6$ Costa Rica earthquake dates back to April 2011. In addition, the rate of earthquakes increased drastically in September 2012, from 11 or fewer per month to 419 (Fig. 4.2)(Waldo Taylor, personal communication 2014). By November, activity was back to background levels. 


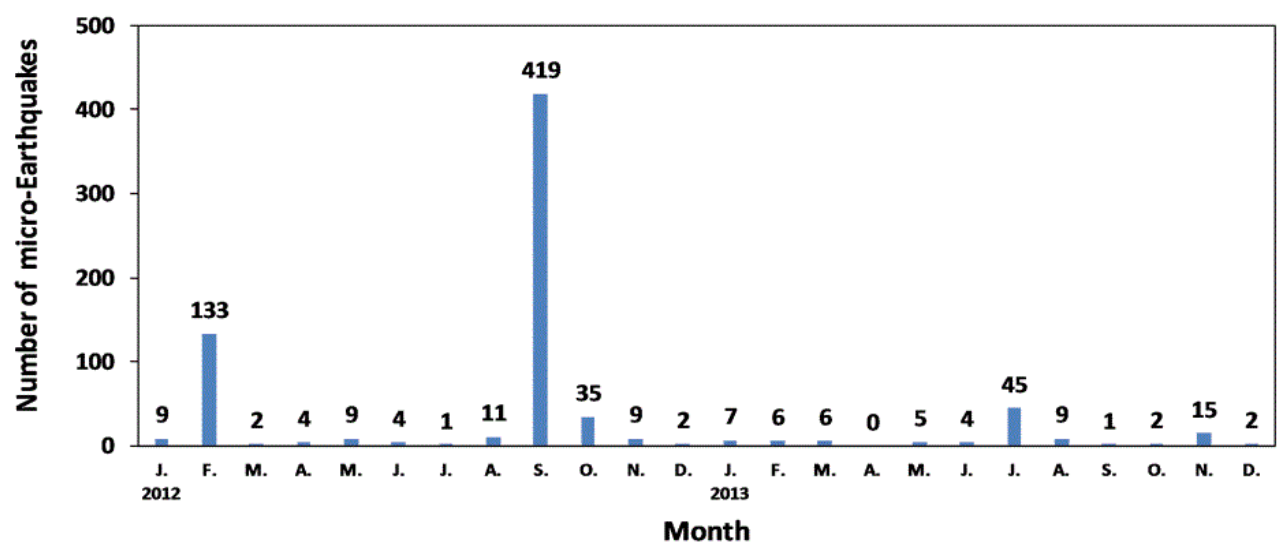

Figure 4.2 - Number of earthquakes each month of 2012 and 2013 at Rincon de la Vieja and proximity. Data from the National Seismic Natwork of Costa Rica (RSN) run by the University of Costa Rica (UCR) and the national electric company (ICE).

Poás recorded several phreatic eruptions on the 27 and 28 October, 2012: water, sediments and rocks were ejected out of the lake that constitutes one of its craters. In one case, a phreatic eruption caused an ashfall event. The same kind of phreatic event, associated with occasional fumarolic activity, repeated itself several times in May-June 2013 and in the days between February and March, and March and April 2014. The latest activity, a phreatic eruption, before the earthquake in analysis dates back to June 2012.

Irazú micro-seismicity greatly increased in the day of the Nicoya earthquake. In the very next few days micro-seismicity was still very high. Normal level was regained 5 days after the Nicoya earthquake (Red Seismological Nacional, 2012).

Turrialba reported several signs of unrest with tremors, rising plumes and ashfall on the period between 29 May and 4 June, 2013. In July 2013, seismic activity (tremors) well above standard has been documented. The latest activity (crater incandescence) before the earthquake in analysis dates back to February 2012. 
Tenorio didn't report any major activity but the seismicity in its proximity drastically increased during the month of Septmber (Fig. 4.3). Already in October, seismicity dropped back to normal levels.

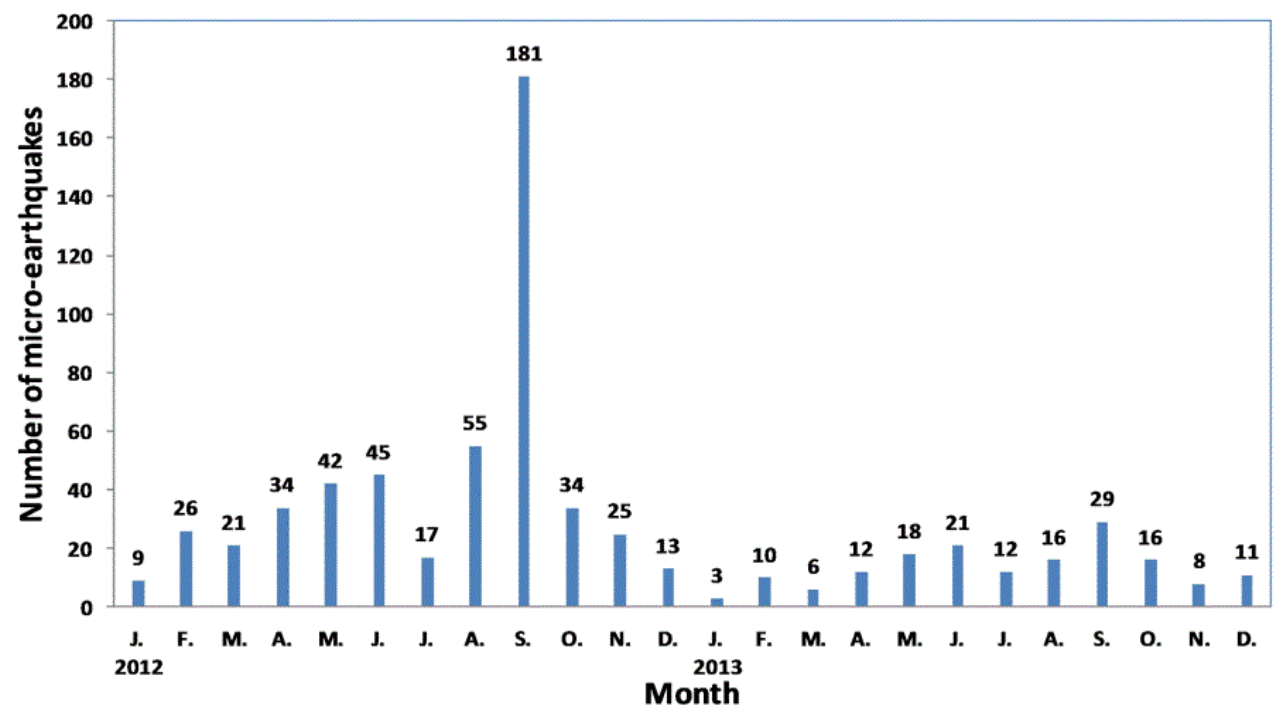

Figure 4.3 - Number of earthquakes each month of 2012 and 2013 at Tenorio and proximity. Data from the National Seismic Natwork of Costa Rica (RSN) run by the University of Costa Rica (UCR) and the national electric company (ICE).

Apoyeque was affected by a seismic swarm on 6 September 2012. No activity before the Mw. 7.6 Costa Rica earthquake is on record.

Cerro Negro was reported to have had enhanced tremors and general seismicity during the early days of June 2013. No activity before the Mw. 7.6 Costa Rica earthquake is on record.

Telica had reported gas and steam rising plumes, fumarolic activity and a couple of small explosions on 10 and 11 September, 2012. Short plumes and incandescence from the crater were also recorded in the following days. The latest activity 
(explosions, tephra and ash emissions) before the earthquake in analysis dates back to May 2011.

San Cristóbal had three big explosions, with subsequent ash and gas plumes, on 8 September 2012. The ash plumes caused significant ashfall events, with ash thickness on the ground up to 5 centimeters near the volcano. Sulfur dioxide emission was reported to be very high and above standard. These kinds of events repeated themselves on 11, 13 and 15 September and later in December 2012, and January and June 2013. Finally, gas and ash emissions were recorded during January, February and April 2014. Prior to the Nicoya earthquake, the most recent activity dates back to August 2011 and refers to gas and ash emission.

All this information is shortly summarized in Appendix B.

\section{Static stress change}

\subsection{Introduction to Static Stress Change}

The term "static stress change" in the scientific literature refers to the change in stress in the Earth's crust caused by the abrupt movement of a seismogenic fault. This change of stress can be considered permanent, in contrast to the transitory stress changes caused by dynamic processes, such as the passing of seismic waves in the crust. King et al. (1994) noted that there are some processes, such as viscous relaxation in the asthenosphere, which may increase the static stress change with time but without influencing its spatial distribution. The static stress change decays

relatively rapidly with increasing distance from the displacement source, as $1 / r^{3}$ (where $r$ is the radius of the circle centered in the earthquake epicenter), so it's 
usually considered effective only in the near-field zone, a few fault lengths away from the epicenter (Manga and Brodsky, 2006; Delle Donne et al., 2010). Linde and Sacks (1998) marked the spatial limit for earthquake induced eruptions to occur, due to static and dynamic processes, at 750 kilometers from the epicenter; while Delle Donne et al. (2010) came up with an empirical relationship relating the magnitude of the earthquake $(\mathrm{M})$ and the maximum radius of response from the epicenter $\left(R_{\max }\right)$, in meters. The equation can be written as follows:

$$
M=-6.4+2.17 \log _{10} R_{\max }(2)
$$

For the Nicoya event, equation 2 yields $R_{\max }=2829 \mathrm{~km}$. All of the volcanoes presented here are within both of these empirical radial limits. In addition to the spatial extent of the influence of earthquakes on volcanoes, one must also consider the time window within which stress changes are important. Static stress is thought to be able to influence volcanic activity for up to five years following the earthquake event (Bonali et al., 2013). Other authors put this limit even further, suggesting that volcanic activity could be directly influenced by a large earthquake even decades after the event (Eggert and Walter, 2009; Marzocchi, 2002).

The minimum value of static stress change needed to cause an eruption has not been constrained and likely varies depending on the state of the volcano prior the earthquake. Manga and Brodsky (2006) summarized the minimum overpressure values needed for dike propagation to $1 \mathrm{MPa}$ and 10-100 MPa, for basaltic and silicic magmas respectively. King et al. (1994), in their work about earthquake triggered seismicity suggest that some events were related to changes of static stress of less than 1 bar (0.1 MPa). Finally, Bonali et al. (2013) related new volcanic activity to various values of normal static stress change, classifying these values as "weak" (increase less than 0.02 MPa), "minor" (change between 0 and - $0.1 \mathrm{MPa}$ ) and "moderate" (change between - 0.1 and - 1.657 MPa). 
As mentioned in Section 1, a change in normal stress can result either in unclamping or clamping of the hypothetical surface feeding system analyzed. Both of these processes are capable of promoting an eruption. The former makes dike intrusion easier by decreasing the value of overpressure needed by dikes to propagate. The latter, though it increases the overall pressure, may have the effect of squeezing part of the magma out of the system ("toothpaste effect") (Bonali et al., 2013 and reference therein). Whatever the trigger or mechanism, there is consensus in the scientific community that the volcano needs to be already in a very critical state in order to be actually affected by these induced changes of stress (Manga and Brodsky, 2006).

\subsection{Methodology-Coulomb 3.3}

The Coulomb 3.3 input data used to calculate the static stress change at our volcanoes comes from the USGS website, from the finite fault model section (http://comcat.cr.usgs.gov/earthquakes/eventpage/pde20120905144207800_35). The input file, based on the finite fault model from Gavin Hayes (Ji et al., 2002) represents the earthquake event subdivided in 225 patches, each one of them positioned in a common coordinated grid and having its own position, rake, dip angle, net slip value and magnitude. It also includes parameters for the characterization of the isotropic, elastic half space, in which the stress produced by the earthquake is experienced. In this study, we used the following values: Young's modulus ( $E=80 \mathrm{GPa})$, Poisson's ratio $(v=0.25)$ and the effective friction coefficient $\left(\mu^{\prime}=0.4\right)$. The regional stress is identified as follows: $\sigma_{1}$ with azimuth of $019^{\circ}$, 
plunge of $0^{\circ}$ and surface stress of $100 \mathrm{bar}, \sigma_{2}$ with azimuth of $090^{\circ}$, plunge of $90^{\circ}$ and magnitude of 30 bar and $\sigma_{3}$ with azimuth of $109^{\circ}$, plunge of $0^{\circ}$ and magnitude of 0 bar

(http://comcat.cr.usgs.gov/earthquakes/eventpage/pde20120905144207800_35).

The input file also provides information about the grid area in analysis. All of these initial parameters were constant in all calculations. Coulomb 3.3, starting from the displacement of the seismogenic fault, computes the strain field in a threedimensional elastic half-space. This is then multiplied by the Young's modulus of the medium to calculate the stress changes at a given location at a given receiver fault. To compute the static stress change at the volcanoes we used the option of calculating the stress on a point, which enables one to specify the precise coordinates and depth of the point of interest. Strike, rake and dip of the receiving fault are also required as input parameters. We chose to analyze the effects of the static stress change on vertical (dip 90 $0^{\circ}$ hypothetical faults. We specified that these be normal faults, but the normal stress calculations should not depend on the faulting style. These parameters would simulate the presence of possible magma conduits (faults, dikes) that could be clamped or unclamped by the change in normal stress provided by the earthquake. The depth parameter was set as 3 kilometers, a reasonable depth for the presence of a magmatic chamber and/or its surface feeding dikes. To considerate different fault orientations, the change of stress has been calculated for various values of strike $\left(0^{\circ}-180^{\circ}\right)$, with an interval of $22.5^{\circ}$. This gave eight different values of strike. Two additional strike values were added, $125^{\circ}$ and $35^{\circ}$, representing, respectively strike directions parallel and orthogonal to the average direction of the Middle American Trench in our area of interest. The former strike value generally also indicates the direction of the Central American Volcanic Arc and thus, simplifying and not accounting for local variations, may be roughly perpendicular to the least horizontal compressive stress and so 
appropriate for dike opening beneath volcanoes in the arc, although Quintero and Güendel (2000) found that the direction of least horizontal compressive stress was approximately N-S in the central part of the arc in Costa Rica. The outputs of the calculations done through Coulomb 3.3 are composed of three numerical values, in bar units, representing the negative or positive amount of shear stress change, normal stress change and Coulomb stress change at the given fault and position. The latter stress change is calculated using the Coulomb Failure Function, which can be written as:

$$
\Delta \sigma_{f}=\Delta \tau_{s}+\mu^{\prime} \Delta \sigma_{n}
$$

where $\Delta \tau_{s}$ is the change in shear stress, $\Delta \sigma_{n}$ the change in normal stress and $\mu^{\prime}$ the effective fault friction coefficient on the receiver fault. A positive value for the Coulomb Failure Function ( $\triangle \mathrm{CFF}$ ) indicates that the receiver fault is closer to failure. For this work, we were mainly interested in the normal stress change results, which indicate whether the receiving fault experience clamping or unclamping. In Coulomb 3.3 convention, unclamping of the fault is represented by a positive stress change, and clamping by a negative one. However, from this point on we will follow the most common convention, where clamping is considerate positive and unclamping negative.

We did not attempt to reconstruct the local geometry of the magma pathway for these volcanoes, as this has been done by Bonali and colleagues (2013). Given more time, this could have been done through GIS software and satellite imagery, since alignments of surface features, such as craters and or parasitic cones, are known to indicate, with a good confidence, the direction of the local $\sigma_{H \max }$ and thus the azimuth of the magma pathway (Nakamura, 1977; Bonali et al., 2011; Corazzato and Tibaldi, 2006). Bonali et al. (2013), in their work calculated the static stress change only on the geometry of the inferred magma pathway. We argue that the geometry of a magma pathway inferred in this way may have changed over the 
years, especially at volcanoes which haven't erupted for a long time (as is the case with some of the volcanoes we examined, see Appendix A), and that a change of stress may help to open and develop new dikes, characterized by new values of strike, from which an eruption may occur. With this assumption we preferred not to follow Bonali et al. (2013) approach but rather to investigate different values of strikes, sampling $360^{\circ}$ with intervals of $22.5^{\circ}$ plus those values parallel and orthogonal to the Middle American Trench.

\subsection{Results of the Static Stress Change Analysis}

The results obtained working with Coulomb 3.3 are summarized and listed in Appendix C. Here we can see the values of normal static stress change related to their receiving fault geometry. All of the calculations have been computed for hypothetical faults at $3 \mathrm{~km}$ of depth. The first thing we can notice is how, concordant with what we expected, the value of static stress change quickly decreases with space: in Fig. 5.1, we can see that it has its maximum at the closest volcano to the epicenter (Tenorio) with a change of $0.0402 \mathrm{MPa}$ and has its minimum at the volcano furthest away (Cosigüina) with a negative change of 0.0004 $\mathrm{MPa}$. 


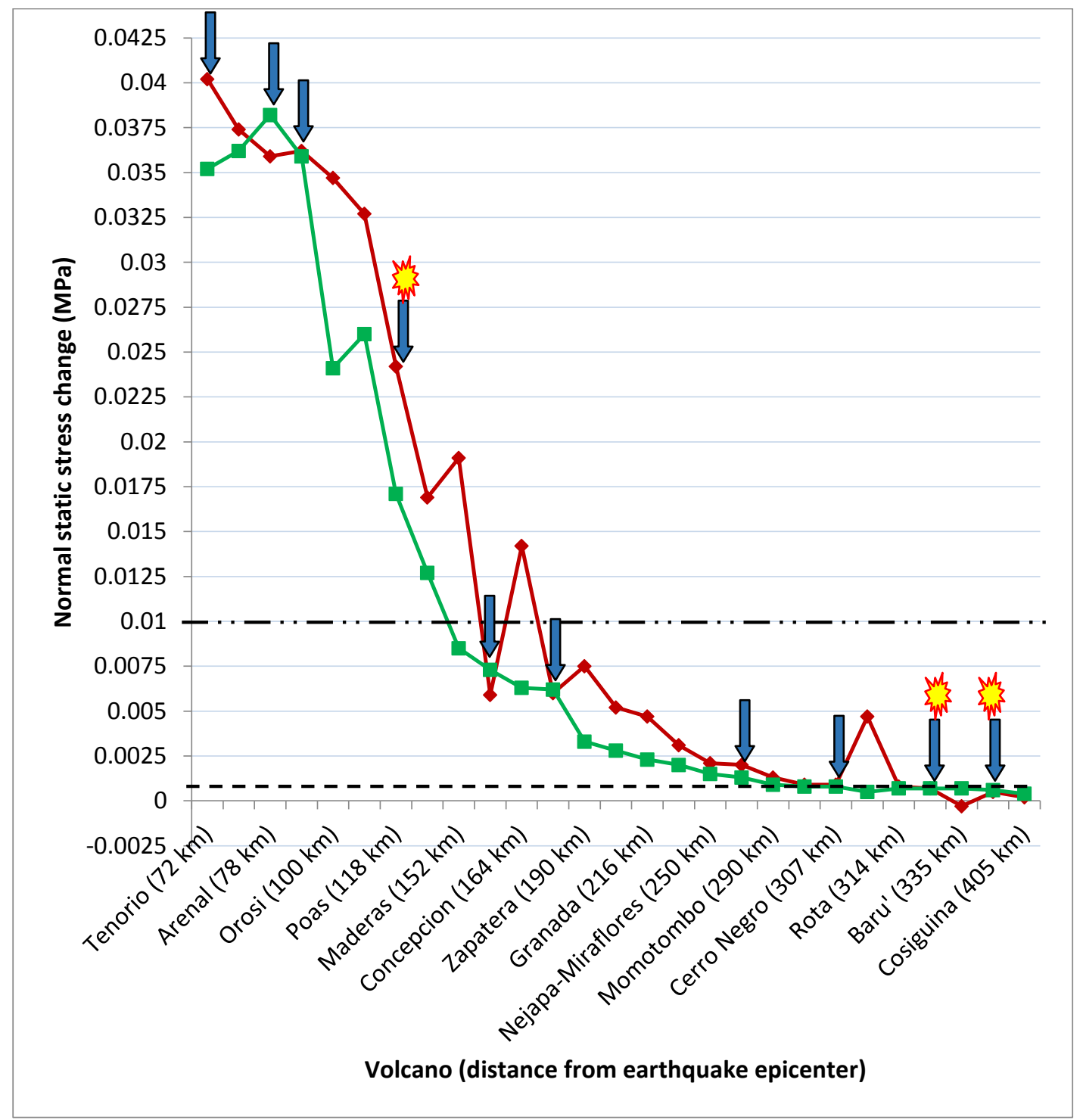

Figure 5.1 - Line graph showing the decrease in the values of normal stress change experience at the volcanoes locations. The red diamond dots represent the values of maximum negative (unclamping) normal static stress change experienced (with the exception of Barú volcano, which experienced only positive stress changes). The green square dots are the absolute values of the maximum positive (clamping) normal static stress change experienced. The long dash and dots line and the dash line show, respectively, the thresholds of normal static stress changes $<0.01 \mathrm{MPa}$ and $<0.001$ MPa. The big blue arrows indicate the volcanoes that had signs of activity following the earthquake, the little explosion marks, those volcanoes that actually erupted following the earthquake. 
We can thus see that even the greatest values, found at the nearest volcanoes, fall into what Bonali et al. (2013) has classified as "weak" changes of stress. Starting from the volcano Turrialba, $168 \mathrm{~km}$ from the epicenter, the values are all under the limit of 0.01 MPa (long dash and dots black line in Fig. 5.1). These values finally decrease another order of magnitude (all values $<0.001 \mathrm{MPa}$, dash black line in Fig. 5.1) beyond Rota volcano, $314 \mathrm{~km}$ away. This is in line with the fact that the static stress change is thought to have influence only in the near field area. Indeed, our seismogenic fault length is about 147 kilometers, we have "weak" responses until about 1.14 times the length of our fault. After this distance our values drop and can be probably classified as "very weak" or "not significant". The "weak" response found even at the closest volcanoes could be related to the magnitude of the earthquake, which was only 7.6. The way we present the obtained data in Fig. 5.1 does not take into account the different values of azimuth of each volcano. Figure 5.2 shows the result for investigating static normal stress change on optimal normal faults (i.e. faults that are optimally oriented to experience the maximum change in stress) in our area of interest. Also from this image we see that the volcanoes clearly influenced by the static stress change produced by the earthquake are only the ones closest to the epicenter. 


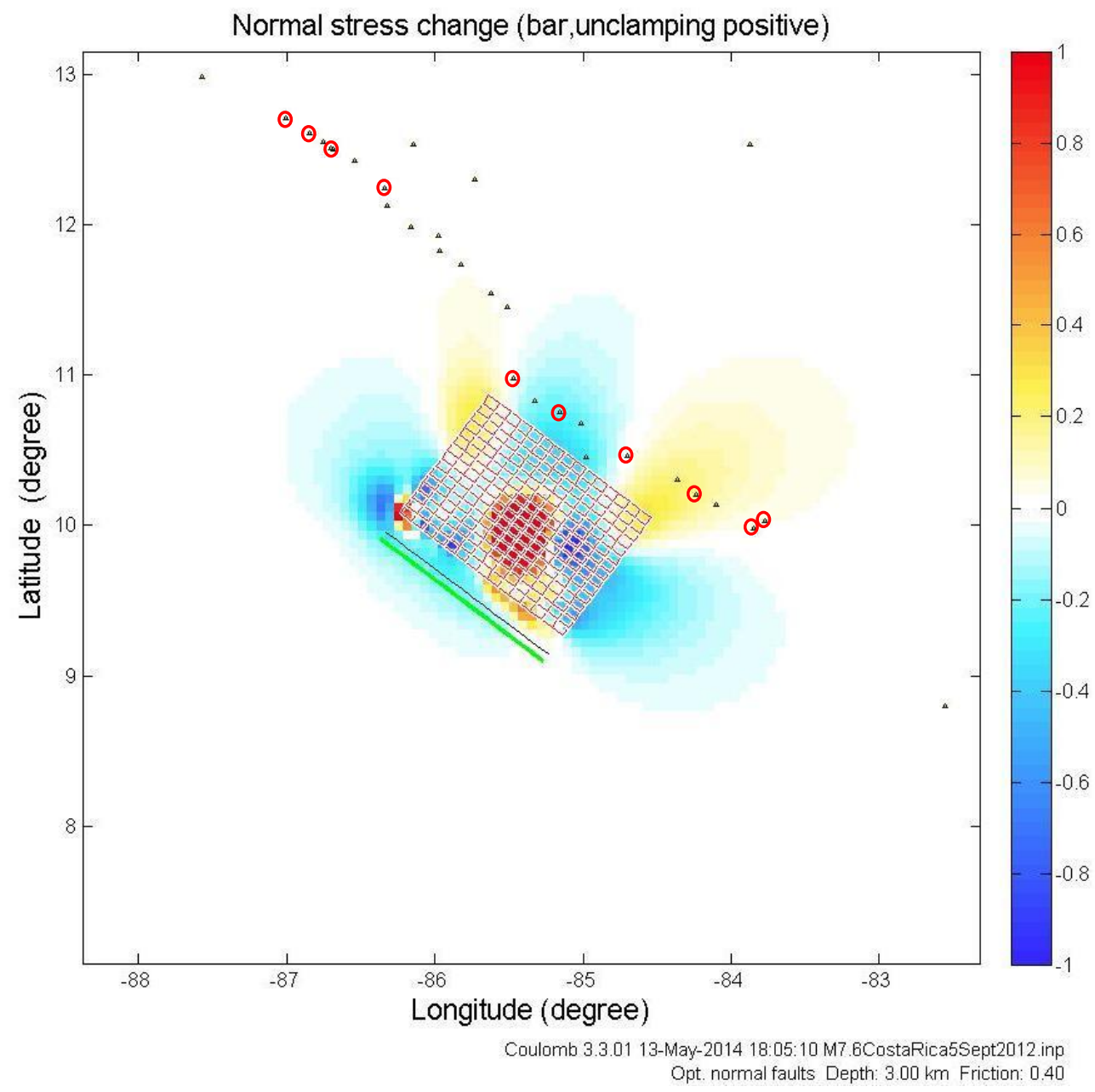

Figura 5.2 - Normal stress change for optimal normal faults in our area of investigation. The ten volcanoes that had signs of activity following the earthquake are circled in red.

Cross-checking these results with the volcanic activity reports taken from the Global Volcanism Program (http://www.volcano.si.edu/), we can see that seven out of the ten volcanoes that showed sign of activity (identified by blue arrows and red circles in Fig. 5.1 and 5.2, respectively) were "weakly" influenced by this normal static stress change, while three out of ten experienced even weaker changes (less than $0.001 \mathrm{MPa})$. 
Shifting our focus to the strike values, we noted that the maximum (unclamping) and minimum (clamping) change of stress were frequently associated with common strike values. This analysis is summarized in Appendix D. In Figure 5.3 and 5.4 we can clearly see that the maximum values of change in normal stress, thus the strongest values of unclamping, are very often associated with faults characterized by a strike almost orthogonal $\left(45^{\circ}\right)$ or orthogonal $\left(35^{\circ}\right)$ to the Middle American Trench and, thus, to the strike of our seismogenic fault. Sixteen out of 29 values follow this pattern. Similarly, almost all of the values of maximum negative change in stress (thus, strongest clamping) are associated with strikes which are almost parallel $\left(135^{\circ}\right)$ or parallel $\left(125^{\circ}\right)$ to the average direction of the Middle American Trench. In this case, 18 out of 30 values suggest this behavior.

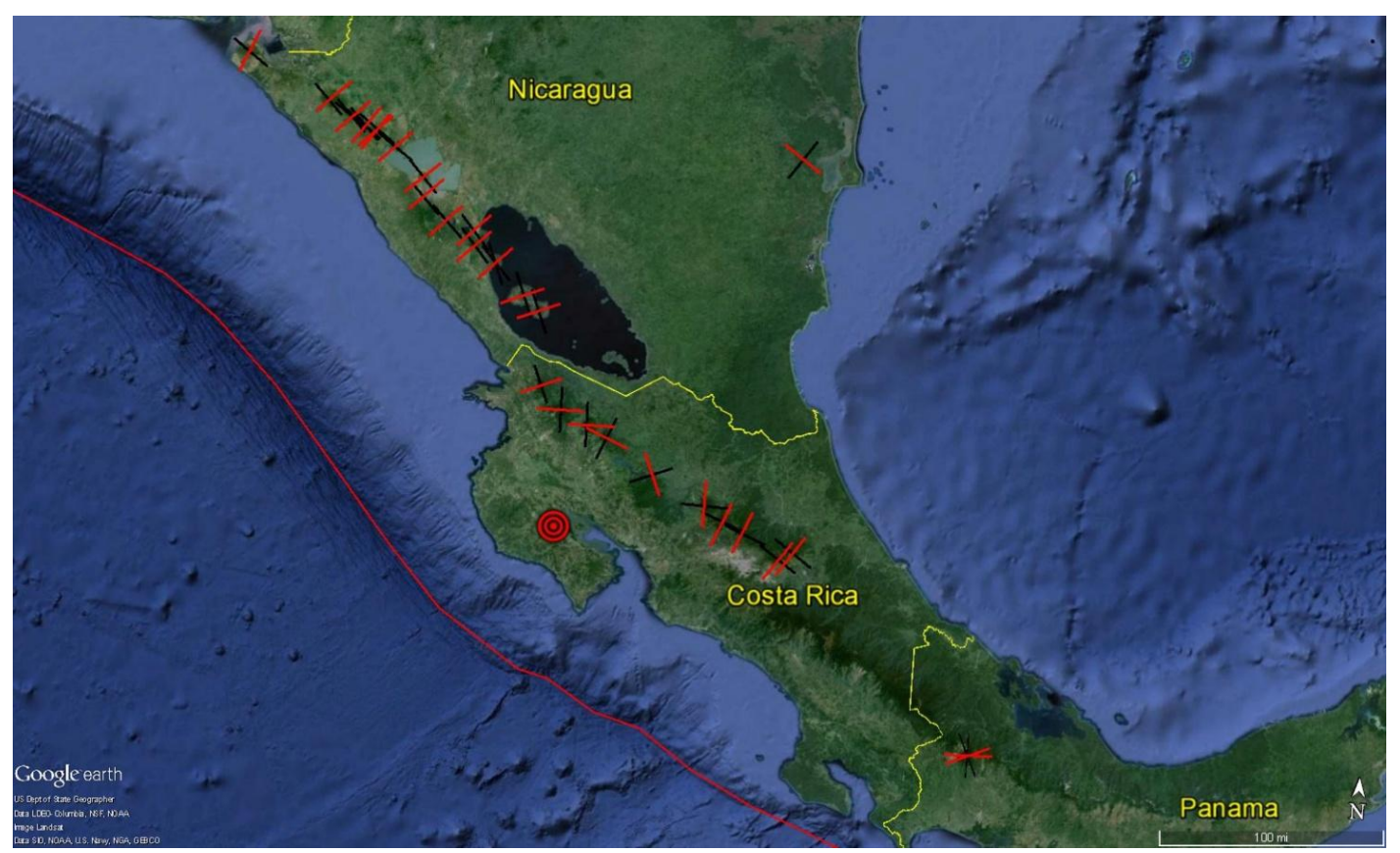

Figure 5.3 - Map showing the orientations of faults at our 27 volcanoes relative to maximum negative (red short lines) and maximum positive (black short lines) change in stress. The earthquake epicenter (red circles) and of the Middle American Trench (long red line) are also shown. Map Data: Google, SIO, NOAA, U.S. Navy, NGA, GEBCO. See Appendix H for documentation of permission to republish this material. 


\begin{tabular}{|c|c|c|c|}
\hline \multicolumn{2}{|c|}{$\begin{array}{c}\text { Values of strike associated to } \\
\text { max negative (unclamping) }\end{array}$} & \multicolumn{2}{|c|}{$\begin{array}{l}\text { Values of strike associated to } \\
\text { max positive (clamping) stress }\end{array}$} \\
\hline stress change & 22.5 & change & 22.5 \\
\hline & $\begin{array}{l}45 \\
67.5\end{array}$ & $110-0$ & $\begin{array}{l}45 \\
67.5\end{array}$ \\
\hline 3 & 90 & & 90 \\
\hline & $\begin{array}{l}112.5 \\
135\end{array}$ & & $\begin{array}{l}112.5 \\
135\end{array}$ \\
\hline 11 & 157.5 & 10 & 157.5 \\
\hline 1$]$ & $\begin{array}{l}125 \\
35\end{array}$ & & $\begin{array}{l}125 \\
35\end{array}$ \\
\hline
\end{tabular}

Figure 5.4 - Pie charts showing the recurrence of strike values (listed on the right, in degrees) when related to the maximum negative (left) and maximum positive (right) values of stress change. 


\section{Dynamic stress change}

\subsection{Introduction}

A dynamic stress change is a transient change in stress due to the passage of seismic waves. Particularly in this area of study, the dynamic stress change is called dynamic in contrast to the static stress change caused by the seismogenic fault, which is considered permanent when considering a finite and not-too-long time of reference. Because they typically have the greatest amplitudes at the surface, surface waves (Love and Rayleigh) carry the largest dynamic stresses. They are characterized by much longer periods than the body waves. Because their energy decays much less rapidly than the body waves', surface waves can thus travel and be effective at much longer distances. Love waves are mainly $S_{H}$ surface waves, while Rayleigh are a combination of $\mathrm{P}$ and $\mathrm{S}_{\mathrm{V}}$. We can thus dominantly see the former in the tangential component and the latter in the radial and vertical ones (Stein and Wysession, 2003). Therefore, we concentrate our analysis of dynamic stress changes to those that are due to surface waves rather than body waves'.

As with the static stress change, the effectiveness of the dynamic stress change is dependent on the magnitude of the earthquake that generated them. However, dynamic stress change influence can be seen at much larger distances and it decays as $1 / r^{1.66}$ (Manga and Brodsky, 2006; Delle Donne et al., 2010). The spatial limit of their real effectiveness upon triggering volcanic events, even if not quite yet understood, can possibly be associated once again with the empirical limits found by Linde and Sacks (1998) and Delle Donne et al. (2010)(Eq. 3) explained in Section 5. Time-wise, the waves effect is only temporary and thus mechanisms are required to maintain this change in stress (Manga and Brodsky, 2006). Many authors have 
proposed several models to explain this process (Manga and Brodsky, 2006), some of these will be explained in the next sub-section.

Compared to the static stress change at the same distance from the epicenter, dynamic induced change in stress is usually bigger, but typical values are similarly in the range of $10^{-2}-10^{-1} \mathrm{MPa}$ (Manga and Brodsky, 2006). As for the static stress change, this means that possibly the volcano effected needs to be already in a critical status in order to be triggered (Manga and Brodsky, 2006). Since dynamic stress change is related to the propagation of seismic waves, its effect is determined by characteristics of the seismic source, such as directivity and radiation pattern (Manga and Brodsky, 2006).

\subsection{Use of dynamic stress change in the context of the work}

Since about half of the volcanoes in analysis are located at more than a fault-length away from the earthquake epicenter, and thus can be described as intermediate or far-field entities, it was necessary to calculate the change in stress caused by the $M_{w}$ 7.6 Nicoya earthquake also from a dynamic point of view. To assess the dynamic stress change experienced by our 27 volcanoes, we proceeded to analyze the waveforms that passed under the 27 volcanoes following the earthquake. As explained later in a more detailed way, the major interesting feature obtainable by these computed waveforms is their amplitude, and thus their peak-to-peak acceleration. This latter, with some assumptions and simplifications, can be easily transformed in units of stress that can give us a rough idea about the amount of increased pressure that the volcanoes experienced. All these processes are further explained in the methodology section. 
The overpressure caused by dynamic stress change is, however, temporary. This requires that a mechanism exist to maintain this gained pressure and thus, if the overpressure is big enough, to lead the volcano to eruption. Many different models have been proposed and continue to be debated (Hill, Pollitz et al. 2002, Manga and Bodsky 2006, Watt, Pyle et al. 2009). The most accepted ones are rectified diffusion, advective overpressure, the creation of new bubbles and the falling of crystal mush roofs (Manga and Brodsky, 2006 and reference therein; Ichihara and Brodsky, 2006).

Rectified diffusion is based on the principle that while seismic waves are passing through the magma chamber of a volcano, the bubbles there present experience cycles of expansion and contraction. This causes, in both cases, a net flux of volatiles between the magma and the bubbles. The bubble will lose gases when squeezed and gain them when stretched. However, the bubble will experience a net gain of volatiles due to the bigger surface area of the bubbles when stretched. Bigger bubbles are more buoyant and this, step by step, can lead to an eruption (Manga and Brodsky, 2006 and reference therein; Ichihara and Brodsky, 2006).

Advective overpressure simply models that, following the passage of seismic waves, more and more bubbles are freed from the chamber walls and surfaces and thus are able to rise, coalesce and generate further overpressure (Manga and Brodsky, 2006 and reference therein).

Another model assesses that even a slight overpressure originated by the passing of seismic waves can provide the supersaturation pressure required to start the nucleation of bubbles (Manga and Brodsky, 2006 and reference therein).

Finally, the falling roof model expects passing seismic waves to shake loose and break the bonds between magma chamber roofs and crystal mush, this latter would 
then sink into the magma body creating a vertical convection in the chamber. Nucleation of bubbles would start in the rising melt and further overpressure would be generated in the magma chamber (Manga and Brodsky, 2006 and reference therein).

The first two models are thought to create overpressure that are probably insignificant and way too weak to lead to an eruption. The last two can possibly lead to more significant changes but would also required many more ideal conditions to be effective. Another limitation of all these models is that they generally oversimplify the whole magma chamber structure, not taking into account many important features, such as its rigidity, level of saturation and so on (Manga and Brodsky, 2006 and reference therein).

\subsection{Synthetic seismograms}

Synthetic seismograms are computed waveforms that approximate and simulate the waveform originated by a given earthquake, and recorded at an arbitrary position. Since there were not real seismograms available for the 27 volcanoes, we computed synthetic seismograms using the CPS program. The program needs several inputs. To model the Earth structure, we used the model AK135-F (Kennett B.L.N. et al., 1995), which is an isotropic, spherical earth, one dimension and constant velocity layered model. For every layer, the model provides information about its thickness, seismic velocities, density and $Q$ values (attenuation quality factor). The program then needs the characteristics of the source mechanism, which are the focal mechanism, depth and moment magnitude of the earthquake in analysis. This information will influence the radiation pattern of the seismic waves 
generated at the earthquake. It finally requires the sampling interval, number of samples and the distance and azimuth from the earthquake epicenter of the location you want to compute the synthetic seismogram at. All this information is used to create body and surface waves phase velocity dispersion curves, their eigenfunctions and finally the Green's functions needed to calculate the synthetics seismograms. The program goes then through a last step filtering the Green's functions, giving as output a three-component time histories related to a particular source mechanism as recorded at a given distance and azimuth. The unit measure of the amplitude of the waves used in the output of this program is $\mathrm{cm} / \mathrm{s}$. Due to some program limitations, we had to simplify the AK135-F Earth model deleting those layers below 2800 kilometers of depth, which represents the outer and inner core of the Earth. The program thus permit to obtain a simplified version of the original waveform passing at given locations. The major limitation of this program is due to the oversimplification of the Earth model used and to the fact that it's impossible to take into account local heterogeneities and structures of the crust. All the data, once the computation on the software was finished, has been further processed with the help of the software MATLAB R2013a (The MathWorks Inc., Natick, MA, 2013).

\subsubsection{Finite fault effects (directivity)}

While for every of the 27 volcanoes we computed synthetic seismograms characterized by a single point source, for the ten volcanoes (except Tenorio and Irazú) that showed signs of activity after the Mw. 7.6 Costa Rica earthquake, we also computed synthetic seismograms using the 80-patch finite-fault model released by the USGS. A finite-fault model takes into account that a seismogenic 
fault doesn't rupture instantly along all its length but that different parts rupture at different times, with different amounts of slip, and with possibly different geometries. These sub-faults also release different amounts of energy (Motazedian and Atkinson, 2005). Due to these facts, the earthquake as a whole may produce a strong directivity, depending mainly on the style and direction of the rupture process.

As explained in Chapter 2, directivity happens when the energy of the seismic waves pile up towards a single direction following the single or dominant direction of rupture of the seismogenic fault (Somerville, 2003). Thus, depending where the point of interest is located, a given location may experience either forward or backward directivity, which results in, respectively, an enhancement or decrease of seismic waves amplitude. For dip-slip faulting, the effects of directivity are mainly focused on regions located updip from the hypocenter, assuming the fault ruptures updip (Somerville, 2003). The $M_{w} 7.6$ Costa Rica earthquake was generated by a reverse fault. The motion of the hanging wall was directed toward the Pacific Ocean and from Fig 2.4 we can see that the rupture of the fault doesn't seem to have a dominant direction. However, the largest slip occurred updip from the hypocenter, meaning directivity effects may be significant. We tested the effects of its possible directivity by computing synthetic seismograms for two points orthogonal to the strike of the seismogenic fault, but located in opposite directions. The two points were roughly at the same distance from the epicenter (60 kilometers). The resulting synthetic waveforms (Fig 6.1), calculated this time only for the vertical component, show a drastic difference. The amplitudes at the oceanward location (with an azimuth of $220^{\circ}$ from the epicenter) are much greater than the one at the landward point ( $30^{\circ}$ of azimuth from the epicenter). For comparison, the peak-to-peak amplitude is $9.22 \mathrm{~cm} / \mathrm{s}$ for the former location and $3.80 \mathrm{~cm} / \mathrm{s}$ for the latter. This suggests a significant directivity effect. The directivity effect can also be seen on the 
duration of the computed waveforms. In Fig. 6.1, we can clearly see how the duration of the landward waveform (on the right) is longer, while the oceanward one is much more compressed. These differences may be important when assessing the mechanisms for triggering volcanoes.
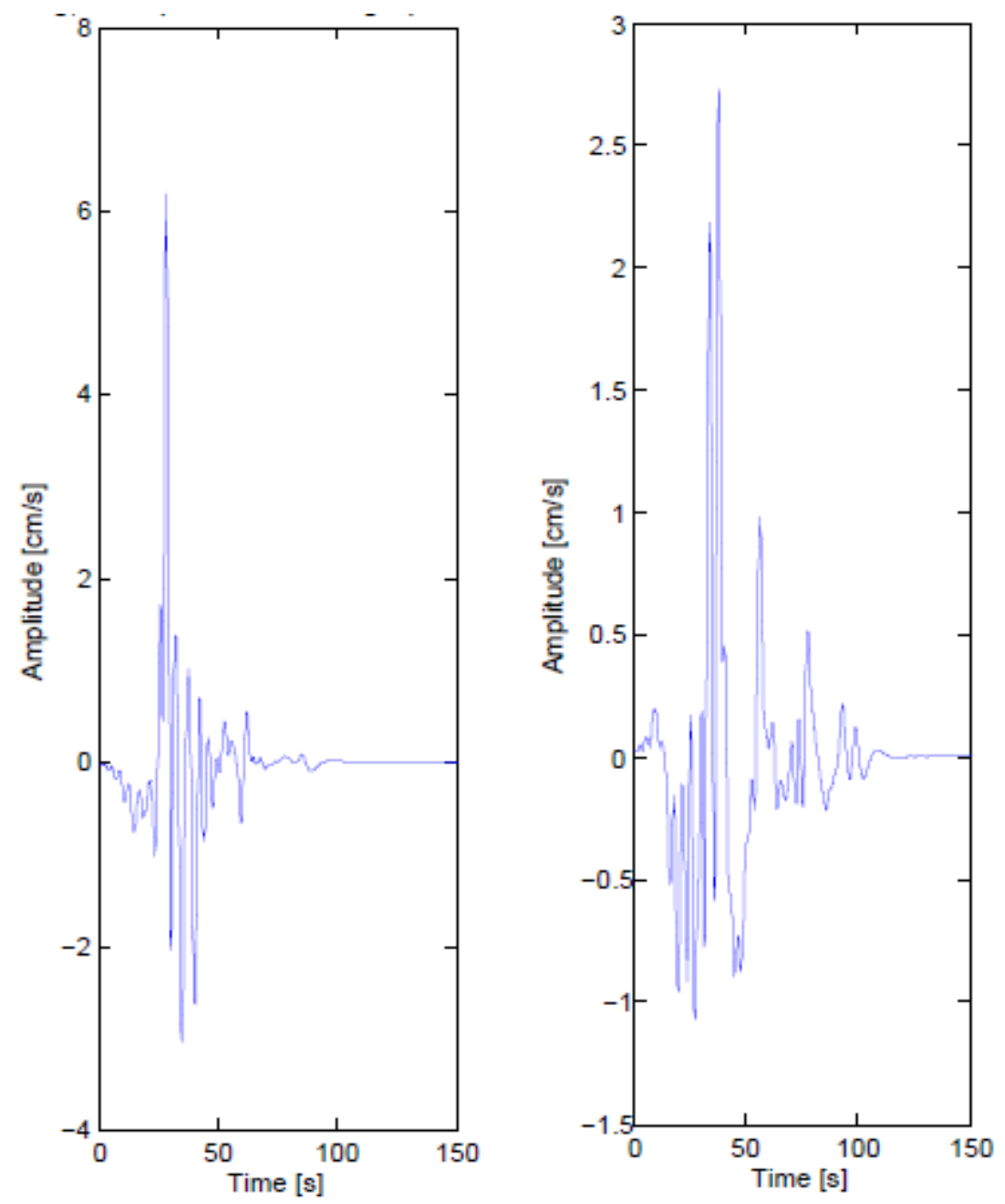

Figure 6.1 - Synthetic seismograms computed to test the effect of directivity. At the oceanward location (left) surface waves show much greater amplitude than at the landward one (right). The duration of the signal is also different. 


\subsubsection{Synthetic seismogram testing}

We tested the codes by making synthetic seismograms for the $M_{w} 7.6$ Costa Rica earthquake at the location of five real seismic stations, taken from the Incorporated Research Institutions for Seismology (IRIS) Data Management Center (http://www.iris.edu). The stations were chosen to be far enough from the earthquake epicenter to show distinct and clear waveforms, they also needed to sample different azimuth. The closest five stations to answer to this need were located in Jamaica (MTDJ station, CU network), Cuba (GTBY, CU), Galapagos Islands and Otavalo in Ecuador (PAYG and OTAV, IU) and Mexico (TEIG, IU). These locations are showed in the map of Fig 6.2.

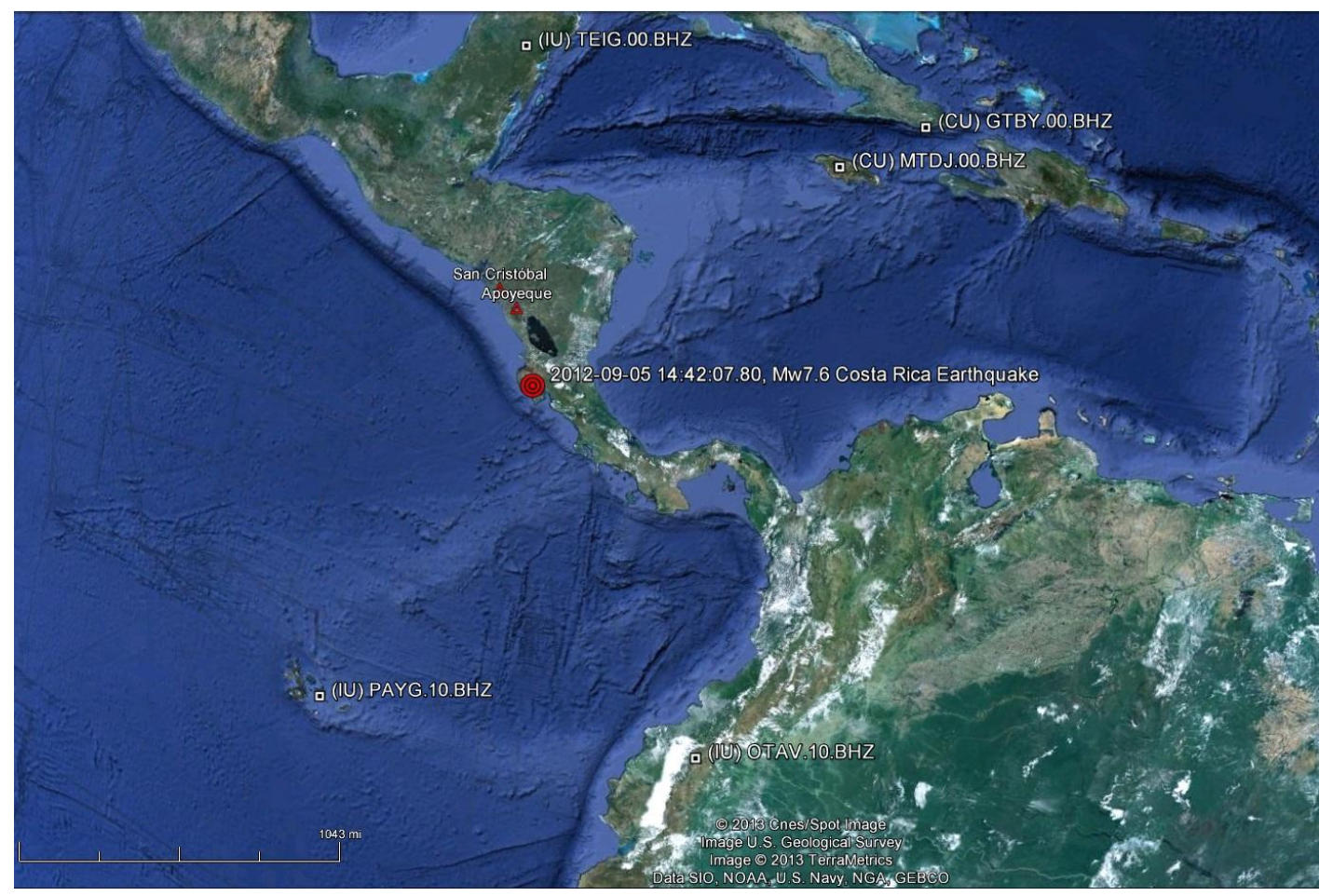

Figure 6.2 - Location of the seismic stations chosen to test the synthetic seismograms computed with Computer Program in Seismology (Herrmann, 2003). Map Data: Google, SIO, NOAA, U.S. Navy, NGA, GEBCO. See Appendix $\mathrm{H}$ for documentation of permission to republish this material. 
In Fig 6.3, the synthetic seismograms are compared to the original seismograms to evaluate the level of accuracy of the program used. First, we deconvolved the instrument response from the real seismograms, giving ground velocity in $\mathrm{cm} / \mathrm{s}$ to allow for comparison with the synthetics. We also filtered both real and synthetic seismograms with a low pass filter (upper cut-off frequency $0.2 \mathrm{~Hz}$ ), to ensure that we could clearly see and compare their surface waves, which comprise the part of the waveform we are most interested in. In Fig. 6.3 we can see how the three seismograms change in amplitude and duration. The change in amplitude is probably due to improperly modeled characteristics of the Earth's structure. Since the seismograms pass through two different Earth's models (one being the real Earth, the other the simplified one-dimensional AK135-F model) and our result is within one order of magnitude of difference, we consider our results to be a good approximation.

The simplified Earth model we used is also responsible for the very different duration of the coda. However, the main bodies of the waveforms, where the greatest amplitudes are found, are similar. Since for this work the most important parameter is the peak-to-peak acceleration, the synthetic seismograms we computed approximate the real waveforms, even if the two don't match perfectly. 


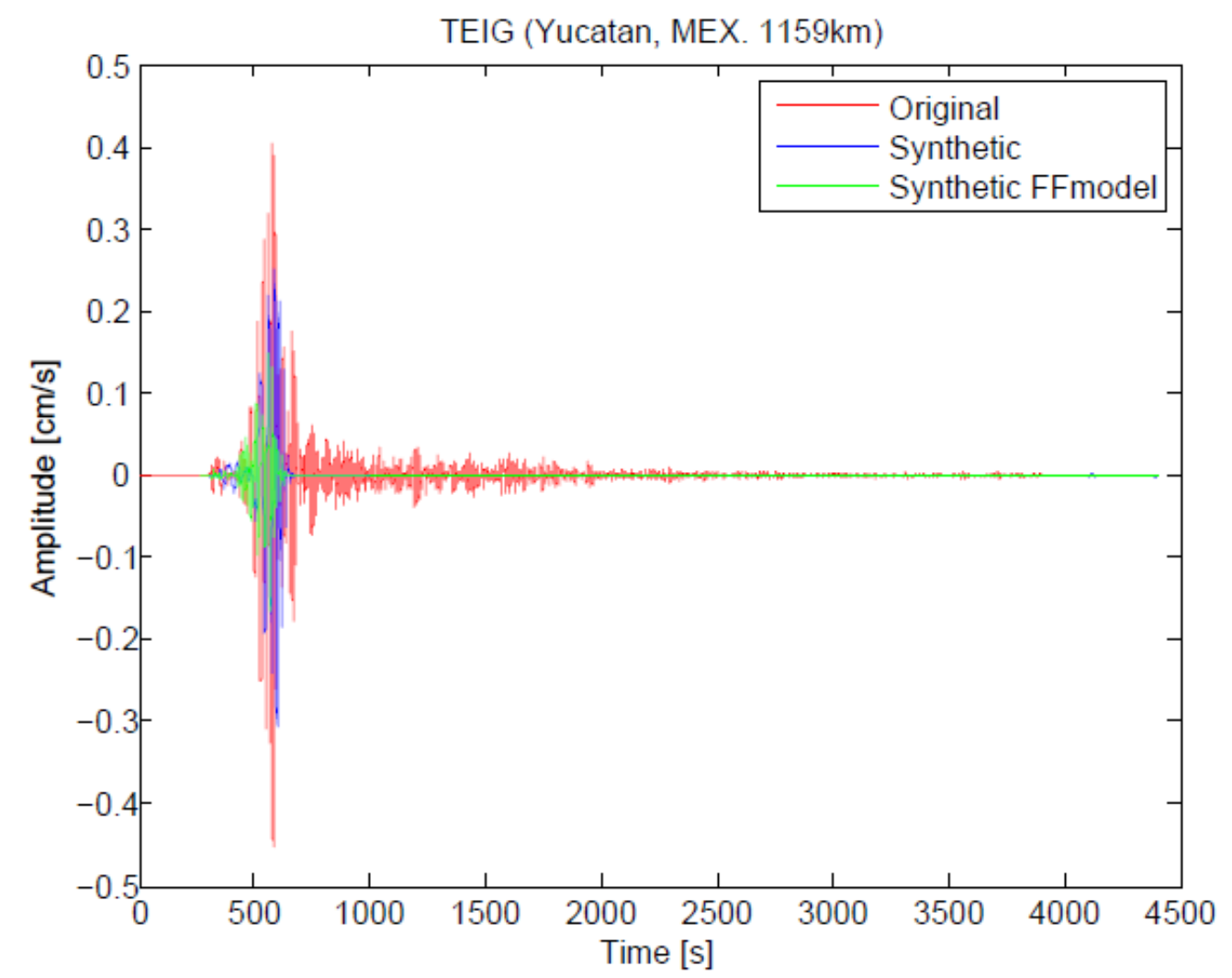

Figure 6.3 - Synthetic seismograms (blue and green) compared with the original seismogram (red) recorded by TEIG station of the Global Seismograph Network. The station is 1159 kilometers away from the Mw. 7.6 Costa Rica earthquake epicenter.

\subsubsection{Synthetic seismograms for the 27 volcanoes}

Once we made sure the synthetic seismograms were similar enough to their hypothetical real counterparts, we computed north, east, and vertical component synthetic seismograms for each of the 27 volcanoes chosen for this work (Fig. 6.4). Using the event-to-volcano azimuth parameters to rotate the north and east traces, we then derived the radial and tangential components. 

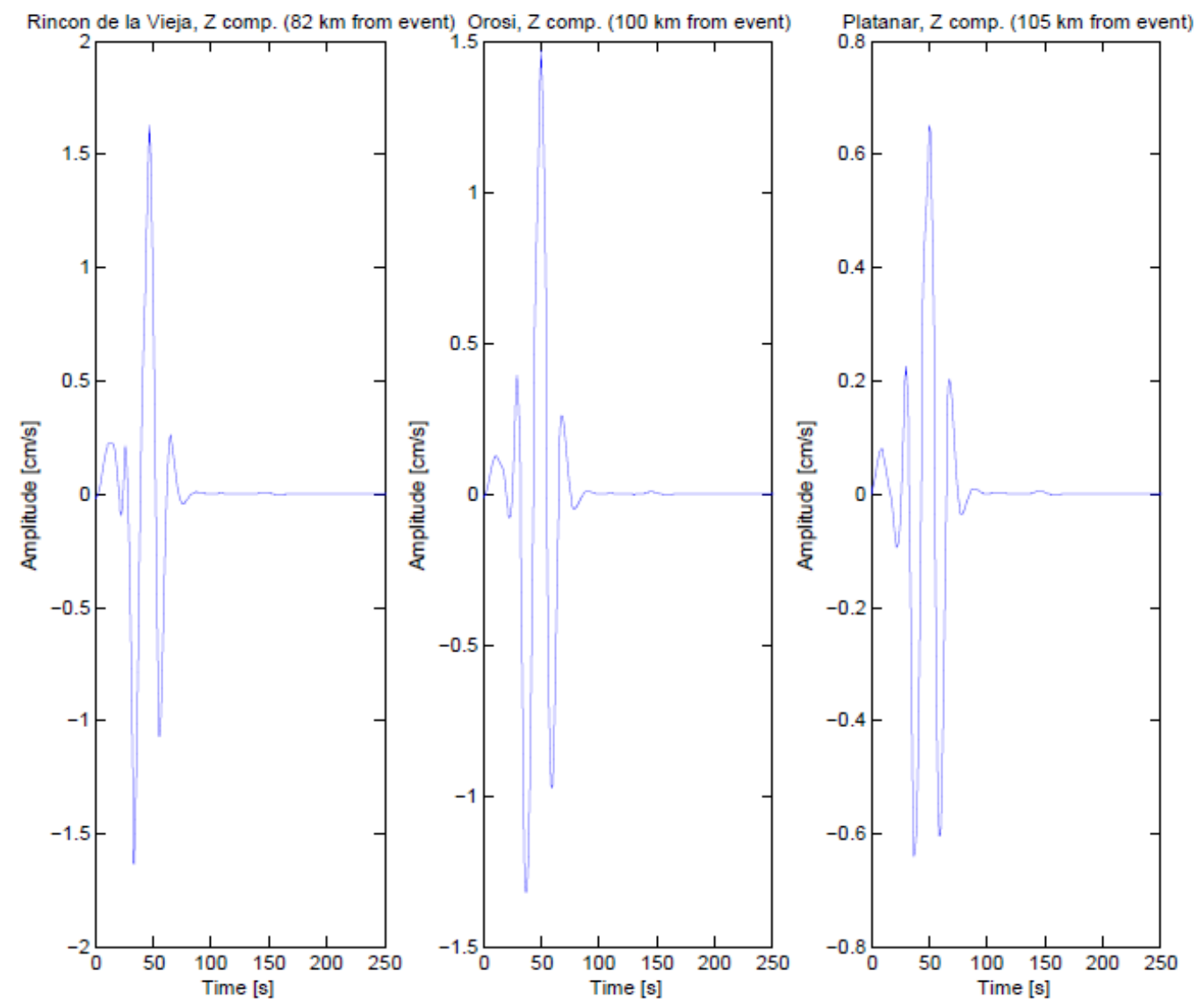

Figure 6.4 - Synthetic seismograms representing the $Z$ component of three volcanoes in analysis.

Using the Fourier transform, we computed the spectra of the waveforms, to investigate their peak frequencies. We used the peak frequencies to verify that the greatest amplitude was released under the form of surface waves, to do this we simply calculate their equivalent period to verify this was roughly between 20 and 50 seconds. This is the range of periods that characterize the highest amplitude surface waves at regional to teleseismic distances (e.g., Hill et al., 2007). From the synthetic waveforms we were able to obtain the peak-to-peak amplitude $(\mathrm{cm} / \mathrm{s})$ of 
the surface waves. This was then used to calculate the Peak Dynamic Stress, in MPa. To do this we follow the approach used by Velasco et al. (2004):

$$
\operatorname{PDS}=v^{*}(\mu / \beta)(4)
$$

where $v$ is the peak particle velocity of the waveform (thus the peak-to-peak velocity), $\mu$ is an average rigidity of the Earth's crust and $\beta$ is the shear wave velocity. When the last two parameters are taken as $\mu=3.3^{*} 10^{11}$ dynes $\mathrm{cm}^{2}$ and $\beta=$ $3.5^{*} 10^{5} \mathrm{~cm} / \mathrm{sec}$, as in Velasco et al. (2004), Equation (4) becomes:

$$
\text { PDS }=v^{*} 0.1
$$

While this approximation is more reliable for shear waves (and by extension Love waves) we also used it for Rayleigh waves which result from interaction of shear and primary waves. We used equation (5) directly with the peak velocities of the single components, focusing on the radial and tangential.

\subsubsection{Synthetic seismograms from finite fault model}

For the ten volcanoes (except Tenorio and Irazú) that showed signs of unrest after the $M_{w} 7.6$ Costa Rica earthquake, we also computed synthetic seismograms starting from the 80-patches finite fault model released by the USGS website (http://comcat.cr.usgs.gov/earthquakes/eventpage/pde20120905144207800_35). Every patch has its own distance and azimuth to the location of the volcano in analysis, its own fault geometry, magnitude, duration and time delay with respect to the seismogenic patch that slipped first. Using the CPS software, we thus computed three components seismograms for every sub-fault. The obtained data was then summed together in MATLAB, taking into account the time delay related 
to every sub-fault. We thus obtained five seismograms (one for every component: $\mathrm{N}, \mathrm{E}, \mathrm{Z}$, plus radial and tangential) that take into account an important effect such as directivity. From these new waveforms, we calculated once again the peak frequencies, peak-to-peak velocities and Peak Dynamic Stresses (Fig 6.5 and 6.6). Finally, we calculated the duration, in seconds, of the seismic wave cycles that exceed an amplitude of $\pm 0.5 \mathrm{~cm} / \mathrm{s}$ and $\pm 1 \mathrm{~cm} / \mathrm{s}$. This was done subtracting the timing of the seismic wave first passage across the amplitude value limit 0.5 or 1 $\mathrm{cm} / \mathrm{s}$ ) to the timing of the seismic wave last passage across that same limit (Fig 6.7). While these values are arbitrary, they provide a means for comparing the relative durations of strong shaking at the different volcanoes. For the obtained duration, the volcanoes experienced oscillations with pressures above or equal 0.05 and 0.1 $\mathrm{MPa}$. To calculate the duration of the application of this overpressure is important because the change in stress caused by dynamic processes is not permanent. Mechanisms, such as rectified diffusion, that are able to convert this stress into permanent stress change are often related to the number of seismic wave cycles passing through the magma chamber of the volcano (Manga and Brodsky, 2006). 


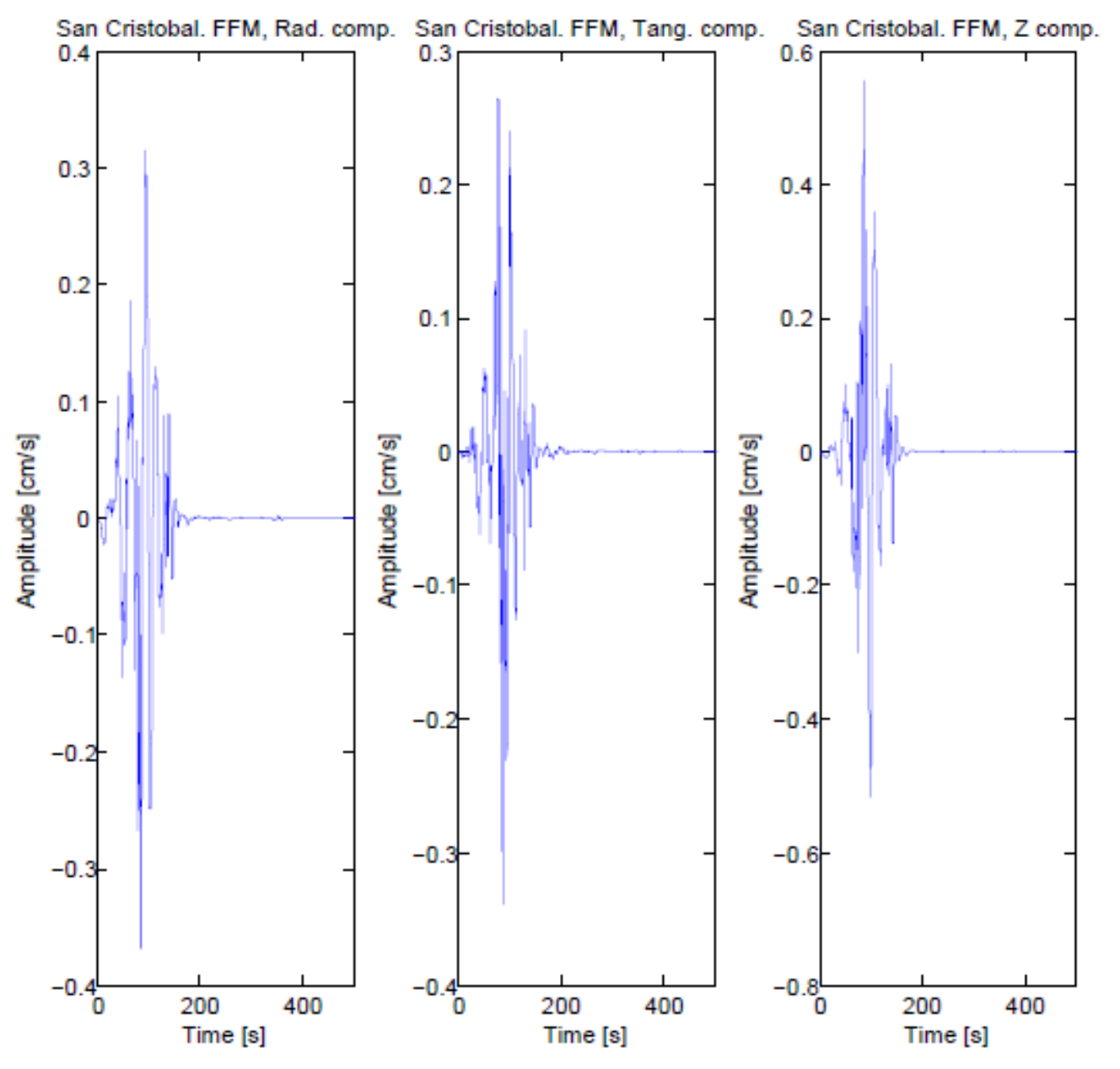

Figure 6.5 - Synthetic seismograms of the Radial, Tangential and Vertical component of San Cristobal volcano. These seismograms were computed starting from the finite fault model released by USGS. 

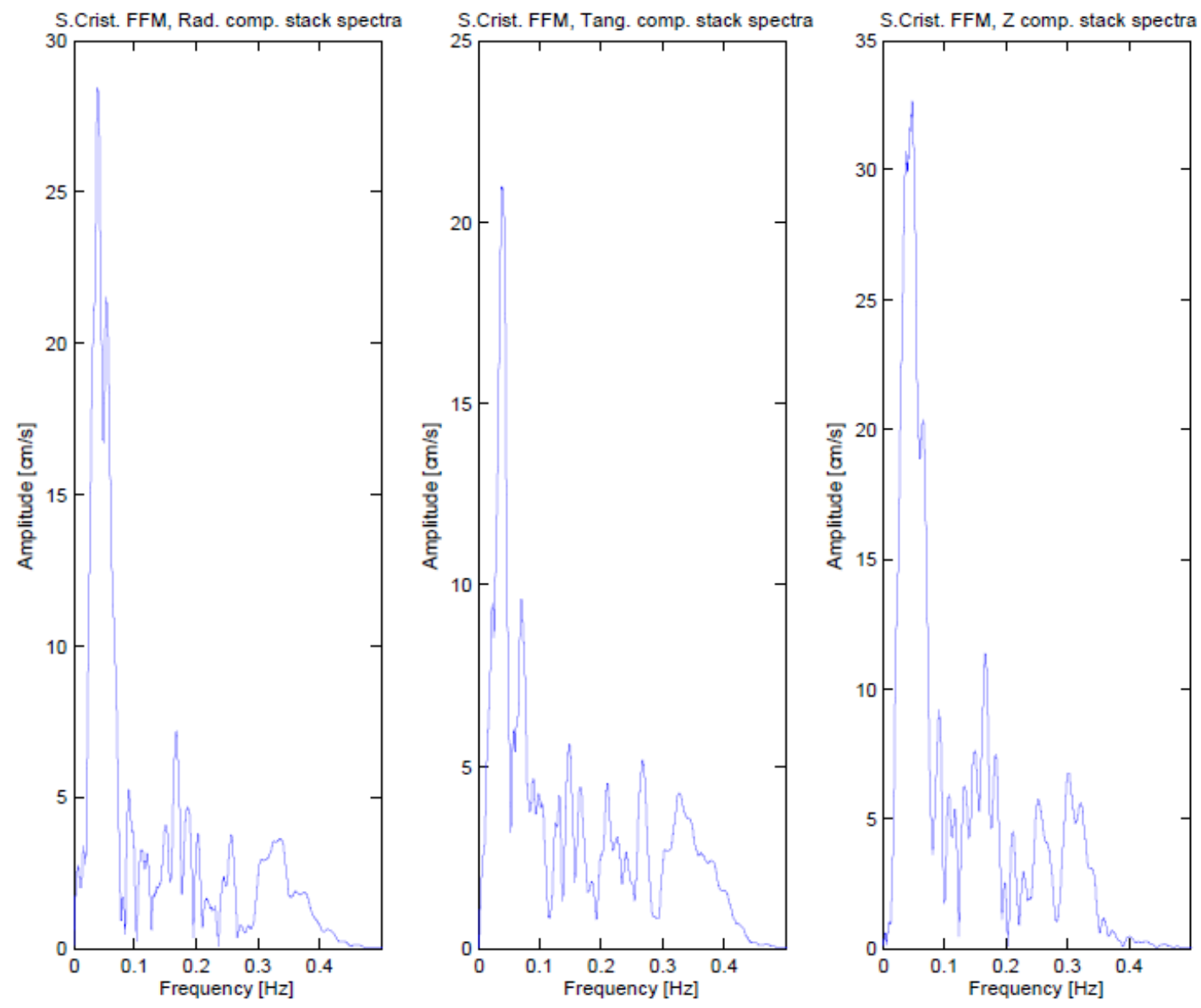

Figure 6.6 - Stack spectra from the radial, tangential and vertical component synthetic finite fault model seismograms of San Cristobal volcano. 


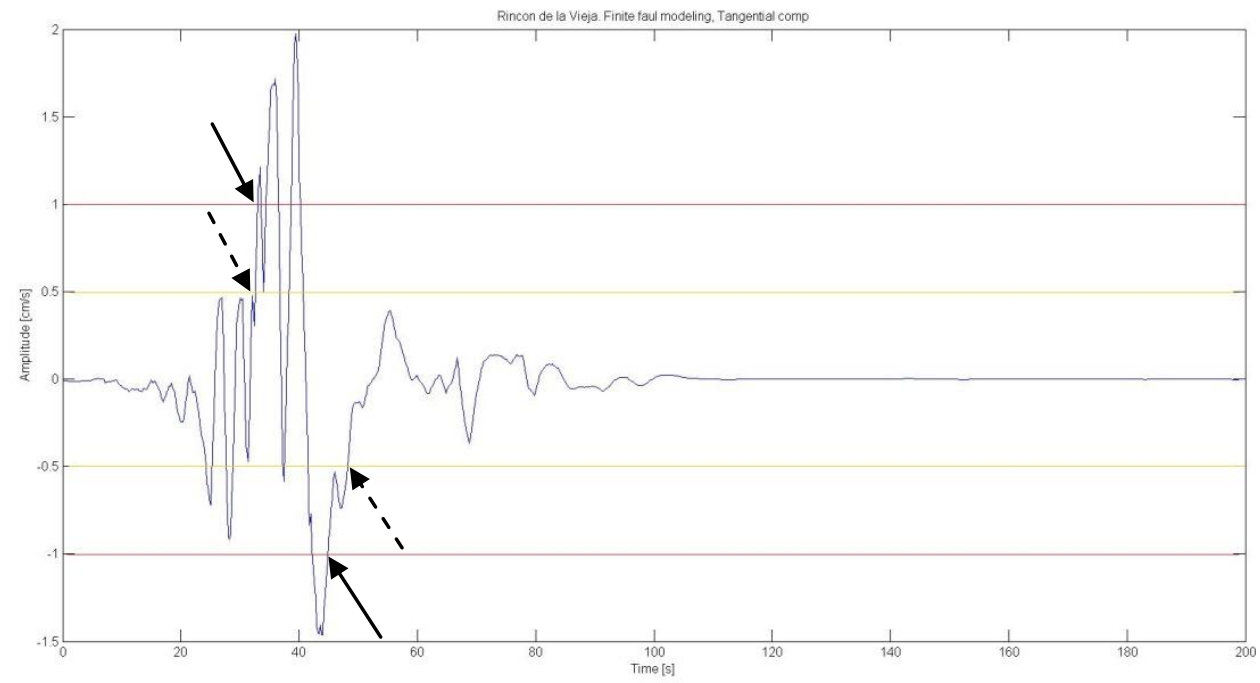

Figure 6.7 - Calculating the duration of the seismic wave cycles with amplitude equal or above \pm 0.5 $\mathrm{cm} / \mathrm{s}$ (golden lines and dashed arrows) and $\pm 1 \mathrm{~cm} / \mathrm{s}$ (red lines and solid arrows). Example from the tangential component of Rincon de la Vieja. 


\subsection{Results}

\subsubsection{Single point source model}

The results obtained through the synthetic seismograms computed starting with a single point source model are summarized in Table 6.1, while a more detailed result table is located in Appendix E.

Table 6.1 - Peak Dynamic Stress related to the Radial and Tangential components. Those volcanoes that showed signs of activity following the earthquake are underlined.

\begin{tabular}{|c|c|c|}
\hline \multirow[b]{2}{*}{ Volcano } & Radial component & Tangential component \\
\hline & $\begin{array}{l}\text { Peak dynamic stress } \\
\text { [MPa] }\end{array}$ & $\begin{array}{l}\text { Peak dynamic stress } \\
{[\mathrm{MPa}]}\end{array}$ \\
\hline Tenorio & 0.440 & 0.250 \\
\hline Miravalles & 0.481 & 0.201 \\
\hline Arenal & 0.335 & 0.357 \\
\hline Rincon de la Veja & 0.462 & 0.263 \\
\hline Orosi & 0.383 & 0.239 \\
\hline Platanar & 0.278 & 0.231 \\
\hline Poas & 0.233 & 0.173 \\
\hline Barva & 0.192 & 0.134 \\
\hline Maderas & 0.211 & 0.136 \\
\hline Irazu' & 0.161 & 0.074 \\
\hline Concepcion & 0.178 & 0.133 \\
\hline Turrialba & 0.154 & 0.068 \\
\hline Zapatera & 0.153 & 0.120 \\
\hline Mombacho & 0.143 & 0.117 \\
\hline Granada & 0.142 & 0.113 \\
\hline Masaya & 0.130 & 0.110 \\
\hline Nejapa-Miraflores & 0.125 & 0.117 \\
\hline Apoyeque & 0.126 & 0.112 \\
\hline Momotombo & 0.118 & 0.105 \\
\hline
\end{tabular}




\begin{tabular}{|l|l|l|}
\hline Las Pilas & 0.113 & 0.101 \\
\hline Cerro Negro & 0.113 & 0.100 \\
\hline Volcan Azul & 0.117 & 0.087 \\
\hline Rota & 0.112 & 0.096 \\
\hline Telica & 0.109 & 0.093 \\
\hline Baru' & 0.109 & 0.024 \\
\hline San Cristobal & 0.105 & 0.112 \\
\hline Cosiguina & 0.096 & 0.065 \\
\hline
\end{tabular}

Fig. 6.8 shows that also the values of Peak Dynamic Stress decrease while increasing the distance between the earthquake epicenter and the volcano. We can also see how the values associated with the radial component are generally higher than the ones associated with the tangential one. The PDS of the radial component experienced at almost all the volcanoes in analysis is above $0.1 \mathrm{MPa}$. Still following the terms used to describe the change in stress by Bonali et al. (2013), these values would, with the exception of Cosiguina, all be considerated "moderate".

The PDS calculated from the tangential component is below $0.1 \mathrm{MPa}$ for 7 out of 27 volcanoes. This change of stress could probably be classified as "minor" or between "minor" and "moderate". Due to the way the PDS has been calculated (Eq. 5), the PDS from the tangential component are more accurate. 


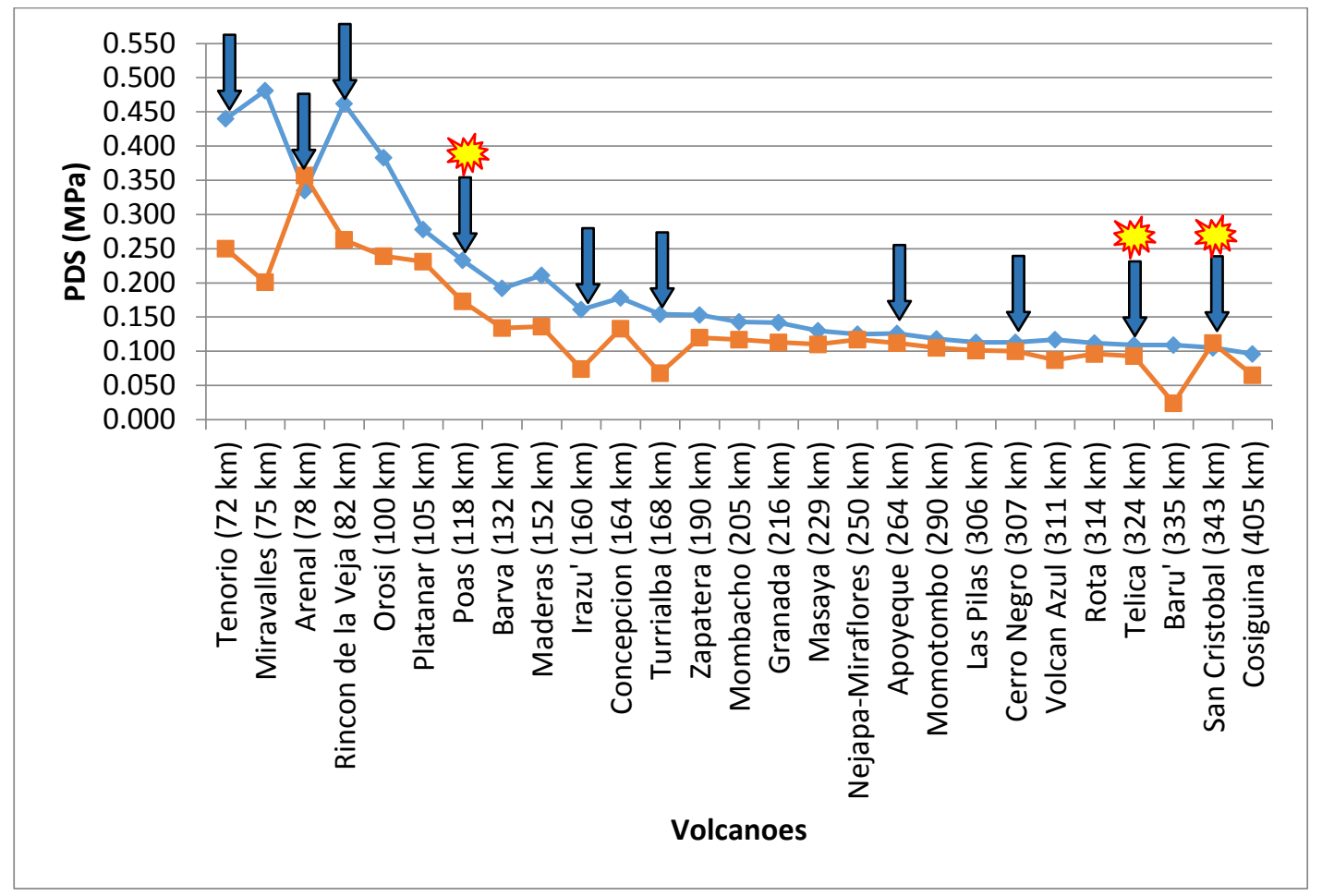

Figure 6.8 - PDS (MPa) from the radial (blue diamond dots) and tangential (orange square dots) components for the 27 volcanoes in analysis. The blue arrows indicates those volcanoes that showed signs of activity following the earthquake, the explosion marks those that actually erupted. 


\subsubsection{Finite-fault model results}

The results obtained for those ten volcanoes (except Tenorio and Irazú) that showed signs of activity following the earthquake are summarized in Table 6.2. For these volcanoes the synthetic seismograms have been computed using the 80 patches finite-fault model released by the USGS. A more detailed result table is located in Appendix $\mathrm{F}$

Table 6.2 - Peak Dynamic Stress related to the Radial and Tangential component.

\begin{tabular}{|c|c|c|c|c|}
\hline \multirow[b]{2}{*}{ Volcano } & \multirow{2}{*}{$\begin{array}{c}\text { Distance } \\
(\mathrm{km})\end{array}$} & \multirow{2}{*}{$\begin{array}{c}\text { Azimuth } \\
\left({ }^{\circ}\right)\end{array}$} & Radial component & Tangential component \\
\hline & & & $\begin{array}{c}\text { Peak dynamic } \\
\text { stress [MPa] }\end{array}$ & $\begin{array}{c}\text { Peak dynamic stress } \\
{[\mathrm{MPa}]}\end{array}$ \\
\hline Arenal & 77.82 & 57.57 & 0.431 & 0.368 \\
\hline Rincon de la Vieja & 82.19 & 358.47 & 0.287 & 0.343 \\
\hline Poas & 117.98 & 84.04 & 0.310 & 0.301 \\
\hline Turrialba & 168.36 & 92.41 & 0.173 & 0.131 \\
\hline Apoyeque & 263.68 & 334.76 & 0.123 & 0.139 \\
\hline Cerro Negro & 307.15 & 330.37 & 0.088 & 0.093 \\
\hline Telica & 324.36 & 329.07 & 0.073 & 0.077 \\
\hline San Cristobal & 343.24 & 327.64 & 0.068 & 0.060 \\
\hline
\end{tabular}

Fig. 6.9 shows that for the volcanoes that synthetic seismograms have been computed from the finite-fault model the radial and tangential PDS is much more similar, when compared to the point-source model. All the volcanoes closer than Cerro Negro volcano, both values are above 0.1 MPa. Cerro Negro, Telica and San Cristobal experience instead PDS values below this limit. Always borrowing the classification from Bonali et al. (2013), these values can be seen as "moderate" and "minor" change in stress. 


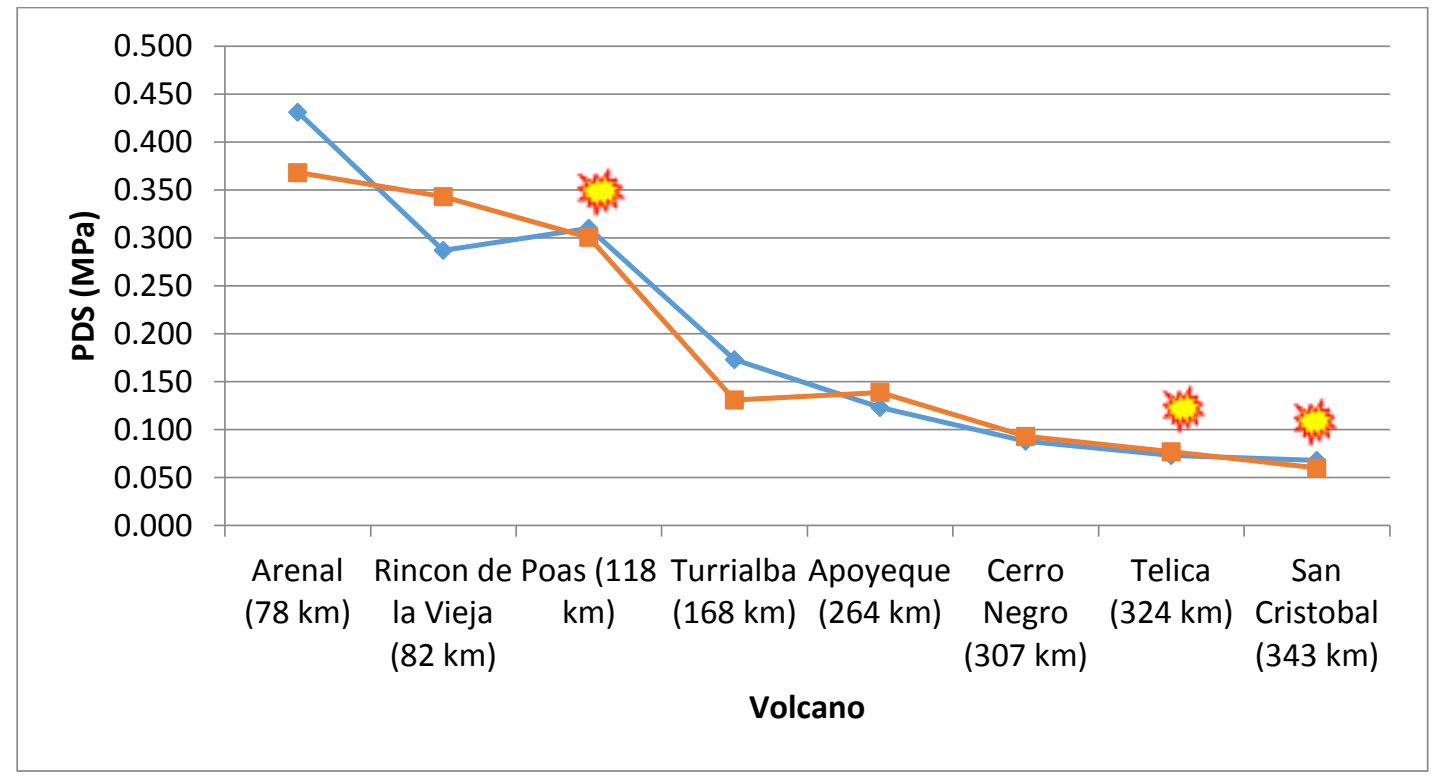

Figure 6.9 - PDS (MPa) from the Radial (blue diamond dots) and Tangential (orange square dots) components for the ten volcanoes (except Tenorio and Irazú) that showed signs of activity following the eruption. The volcanoes that actually erupted following the earthquake are marked by the red and yellow explosion mark.

Table 6.3 shows the durations in seconds of seismic waves cycles that exceeded \pm 0.5 and $\pm 1 \mathrm{~cm} / \mathrm{s}$. The values represent, respectively, 0.05 and $0.1 \mathrm{MPa}$. We can see how the duration of the cycles decreases while increasing the distance between the epicenter and the analyzed volcano. For the three volcanoes farthest away, the amplitude of the seismic wave is always below the $0.5 \mathrm{~cm} / \mathrm{s}$ limit, while for the closest ones the duration of the seismic wave cycles crossing the $0.5 \mathrm{~cm} / \mathrm{s}$ limit reaches tens of seconds. The longest durations are found at Arenal volcano, where the tangential component had cycles crossing the $0.5 \mathrm{~cm} / \mathrm{s}$ amplitude limit for 34.5 seconds and the $1 \mathrm{~cm} / \mathrm{s}$ one for 21 seconds. 
Table 6.3 - Durations in seconds of seismic waves cycles that exceeded \pm 0.5 and $\pm 1 \mathrm{~cm} / \mathrm{s}$ at the 8 volcanoes.

\begin{tabular}{|c|c|c|c|c|}
\hline \multirow{2}{*}{$\begin{array}{c}\text { Volca } \\
\text { no }\end{array}$} & $\begin{array}{c}\text { Ruration (s) of } \\
\text { signal greater than } \\
\pm 0.5 \mathrm{~cm} / \mathrm{s}(0.05 \\
\mathrm{MPa})\end{array}$ & $\begin{array}{c}\text { Duration (s) of } \\
\text { signal greater than } \\
\pm 1 \mathrm{~cm} / \mathrm{s}(0.1 \mathrm{MPa})\end{array}$ & $\begin{array}{c}\text { Duration (s) of } \\
\text { signal greater than } \\
\pm 0.5 \mathrm{~cm} / \mathrm{s}(0.05 \\
\mathrm{MPa})\end{array}$ & $\begin{array}{c}\text { Tangential } \\
\begin{array}{c}\text { Duration (s) of } \\
\text { signal greater than } \\
\pm 1 \mathrm{~cm} / \mathrm{s}(0.1 \mathrm{MPa})\end{array}\end{array}$ \\
\hline $\begin{array}{c}\text { Arena } \\
\text { I }\end{array}$ & 19.9 & 16.4 & 34.5 & 21 \\
\hline $\begin{array}{c}\text { Rinco } \\
\text { n de } \\
\text { la } \\
\text { Vieja }\end{array}$ & 26.7 & 16.7 & 23.8 & 12 \\
\hline $\begin{array}{c}\text { Poas } \\
\text { Turria } \\
\text { Iba }\end{array}$ & 14.7 & 11.7 & 33.6 & 10 \\
\hline $\begin{array}{c}\text { Apoye } \\
\text { que }\end{array}$ & 1.2 & 0 & 29.2 & 0 \\
\hline $\begin{array}{c}\text { Cerro } \\
\text { Negro }\end{array}$ & 0 & 0 & 2.8 & 0 \\
\hline Telica & 0 & 0 & 0 & 0 \\
\hline $\begin{array}{c}\text { San } \\
\text { Cristo } \\
\text { bal }\end{array}$ & 0 & 0 & 0 & 0 \\
\hline
\end{tabular}




\section{Statistical Analysis}

\subsection{Introduction}

Volcanic activity in the days immediately following an earthquake event is instinctively regarded as a strong sign of correlation between the two phenomena. This correlation becomes weaker while time passes and it can become very difficult to establish if the activity has been triggered or is just part of the normal background activity of the volcano (Linde and Sacks, 1998; Manga and Brodsky, 2006; Avouris, 2011). A statistical analysis taking into account the history of the volcano and its average recurrence period for eruptions can give important insights on this subject.

\subsection{Methodology}

For the three volcanoes that actually had eruptions following the earthquake (Poas, Telica and San Cristobal) we proceeded to do a simple statistical analysis to evaluate the probabilities for the volcano to have an eruption following the earthquake event if not triggering had occured. Starting with the data collected from the catalog of the Smithsonian Institution Global Volcanism Program (http://www.volcano.si.edu/), we calculated the time-independent Poisson probability and two time-dependent probabilities.

The Poisson probability calculated the chance of having an eruption in some time period based on the average time between eruptions. In our case, the time period of interest is the time between the Nicoya earthquake and the volcano first 
following eruption. This model, which does not take into account theabsolute times of the events in the eruption catalog, can be expressed as follows:

$$
p(n \geq 1, t, \tau)=1-e^{-t / \tau}(6)
$$

where $p$ is the probability of having at least one event, $t$ is the time window considered and $\tau$ is the mean recurrence time among the events in the catalog.

The time-dependent probabilities, on the other hand, take into account the date of the last eruptive event before the earthquake. They thus may be appropriate for models where a recharge period between eruptive events is required. The first calculation represents the probability of the volcano erupting in the time period that spans between the earthquake and the following eruption. The second, the probability of an eruption within one year after the earthquake. These values were calculated as:

$$
p(t, \tau, \sigma)=\frac{1}{\sigma \sqrt{2 \pi}} \exp \left[\frac{-1}{2}\left(\frac{t-\tau}{\sigma}\right)^{2}\right]
$$

where $p$ is the probability, $t$ is the time window considered, $\tau$ is the mean recurrence time among the events in the catalog and $\sigma$ the standard deviation. In this approach we assume that the recurrence of eruptive events follows the normal distribution. An obvious drawback to this work is a lack of a complete catalog of activity and a relatively short time window of activity on which to compute recurrence intervals. For comparison, we also calculated probability an event occurring within one year of the Nicoya earthquake for two other volcanoes (Conception and Masaya) that, as of 05/15/2014, didn't show any signs of activity following the earthquake. All the data used in these calculations can be seen in Appendix G. 


\subsection{Results}

The results of the statistical analysis are listed in Table 7.1. We can see that the probabilities are very low for San Cristobal volcano and Telica, low to medium for Poas. The fact that activity occured despite the low probabilities, further suggests a strong correlation between the $M_{w} 7.6$ Costa Rica earthquake and the ensuing eruptive activity at the surrounding volcanoes. We found low to medium-low probabilities of an eruption within one year of the earthquake event also for the volcanoes that did not have an eruption following the earthquake.

Table 7.1 - Results of the statistical analysis.

\begin{tabular}{|c|c|c|c|}
\hline Volcano & $\begin{array}{c}\text { Poisson } \\
\text { prob. (\%) }\end{array}$ & $\begin{array}{c}\text { Time-dep. prob. occurring in } \\
\text { interval (\%) }\end{array}$ & $\begin{array}{c}\text { Time-dep. prob. occurring within } \\
1 \text { year (\%) }\end{array}$ \\
\hline $\begin{array}{c}\text { San } \\
\text { Cristobal }\end{array}$ & 0.75 & 0.09 & 7.75 \\
\hline Poas & 29.94 & 11.33 & 55.75 \\
\hline Telica & 1.44 & 0.35 & 20.27 \\
\hline $\begin{array}{c}\text { Concepti } \\
\text { on }\end{array}$ & N/A & N/A & 0.31 \\
\hline Masaya & N/A & N/A & 8 \\
\hline
\end{tabular}




\section{Discussion}

Interactions between earthquake events and volcanic phenomena is now widely accepted. Many authors have shown how static and dynamic stress released by moderate to large earthquake can influence the activity of volcanoes, both in the near-field and at teleseismic distances (Linde and Sacks, 1998; Manga and Brodsky, 2006). The correlation seems to be stronger when volcanoes show signs of activity in the few days following the earthquake events (Avouris, 2011), but studies have suggested that the latter can influence volcanic systems up to decades after the event (Eggert and Walter, 2009; Marzocchi, 2002). In this study, ten volcanoes showed signs of activity after the event considered. Four of them (Apoyeque, Irazú, Telica and San Cristobal) in the very next few days, Poas around 53 days after, Turrialba and Cerro Negro 9 months after, and finally, Arenal around 1 year after the event. Among these ten volcanoes, only Poas, San Cristobal and Telica actually erupted. The other showed minor signs of activity and unrest.

There have been some attempts to classify the response of volcanoes based on their geochemistry and the characteristics of their conduit (e.g. Bonali et al., 2013; Avouris, 2011). All the volcanoes here presented that had activity following the earthquake, except Apoyeque, are basaltic. However, so too are, nearly all the other 19 volcanoes considered in this study. The values of static and dynamic stress change we obtained are all on the order of $10^{-1}$ and $10^{-2} \mathrm{MPa}$, with the dynamic stress change values predominantly in the former order of magnitude and the static stress change ones in the latter. These values can be considered from "moderate" to "minor", but even very small values of stress change can trigger an eruption, assuming that the volcano system considered is already in a critical state (Bonali et al., 2013; Manga and Brodsky, 2006). In their paper, Manga and Brodsky (2006), 
suggest that in normal cases the change in stress is naturally so small that, although its effect is significant, the overpressure in the volcanic system must be already "within 99\%-99.9\% of the maximum overpressure for the earthquake to initiate an eruption" (Manga and Brodsky, 2006).

Another important factor is to find a way to distinguish induced activity from the normal background activity of the volcano. This can be done with statistical analysis of the eruptive history of the volcano. The statistical analysis that we computed show that, despite the small amount of stress change experienced by the volcanoes that erupted, the probability of a volcanic event in the time interval between the earthquake and the first eruption at Poas, Telica and San Cristobal was very low to low. This is suggestive of a strong correlation between the two phenomena. San Cristobal, for example, experienced an insignificant amount of normal static stress change (0.0005 MPa) and a low amount of dynamic stress change, with only 0.06 $\mathrm{MPa}$ as Peak Dynamic Stress. However, the statistical analysis indicates that the probability of not having an eruption in the time period between the 5 and 8 September 2012 (date of the earthquake and the eruption at San Cristobal volcano, respectively) was of $99.91 \%$. Despite having less than $0.1 \%$ of probability of erupting, San Cristobal manifested a vulcanian eruption.

The same can be said for Poas and Telica. Our conclusions are also supported by the significant increase of seismicity throughout Costa Rica, and especially at some volcanoes, recorded by the Costa Rica seismic network (Red Seismological Nacional http://www.rsn.ucr.ac.cr/index.php/es/).

On 27 August 2012, a previous megathrust earthquake of $M_{w} 7.3$ struck off the coast of El Salvador. It is important to mention its existence, but we argue that, being of similar magnitude and characteristics, also its values of static stress change would have been not very significant. The sum of the static stress change of the two 
earthquakes wouldn't thus show a lot of differences from our calculations. We speculate that also the Peak Dynamic Stress values from that previous earthquake would have probably be of the same order of magnitude of the values we obtained.

\section{Conclusion}

In our study, we quantified the static and dynamic stress changes experienced at 27 volcanoes of the Central American Volcanic Arc following the $M_{w} 7.6$ Costa Rica earthquake of 5 September 2012. The aim of the study was to contribute to the understanding of this complicated phenomena of earthquake-volcano interaction, giving an insight linked to this particular Central American case. Our results indicate that the change in stress experienced by the volcanoes following the earthquake has been very small, in the order of $10^{-1}-10^{-2} \mathrm{MPa}$. Even so, the statistical analysis, computed for those three volcanoes that actually erupted following the earthquake, indicates a strong relationship between the two phenomena. We thus suggest that, given the limitations we had to embrace, the volcanic activity recorded following the earthquake has indeed been triggered. If this is the case, this study shows more than ever how the status of the magmatic system at the time of the earthquake event plays an extremely important role, since it appears than even a very small amount of change in stress can lead to an eruption.

Future work should include steps to minimize the simplification necessary in the computation of the synthetic seismograms, should consider in a more detailed way the geometry, geochemistry and characteristic of the magmatic system of the volcanoes involved in the study and, finally, should try to use a more complete catalog, when analyzing the eruptive history of the volcanoes. It would also be beneficial to focus on a smaller number of volcanoes, in order to be able to spend more time in a more detailed characterization of fewer cases. 


\section{References}

Alvarez-Gomez J., Meijer P. T., Martinez-Diaz J. J., Capote R., 2008. Constraints from finite element modeling on the active tectonics of northern Central America and the Middle America Trench. Tectonics 27, TC1008.

Ammon C. J., Velasco A. A., Lay T., 1993. Rapid estimations of rupture directivity: application to the 1992 Landers $\left(M_{S}=7.4\right)$ and Cape Mendocino $\left(M_{S}=7.2\right)$, California earthquakes. Geophysical Research Letters 20, 97-100.

Avouris D. M., 2011. Triggering of volcanic activity by large earthquakes. Unpublished Master's thesis. Michigan Technological University.

Beresnev I. A., Atkinson G. M., 1999. Generic finite-fault model for ground-motion prediction. Bull. of the Seism. Soc. of America 89, 608-625.

Bonali F. L., Corazzato C., Tibaldi A., 2011. Identifying rift zones on volcanoes: an example from La Réunion island, Indian Ocean. Bull. Volcanol. 73, 347-366.

Bonali F. L., Tibaldi A., Corazzato C., Tormey D. R., Lara L.E., 2013. Quantifying the effect of large earthquakes in promoting eruptions due to stress changes on magma pathway: The Chile case. Tectonophysics 583, 54-67.

Bray J. D., Rodriguez-Marek A., 2004. Characterization of forward-directivity ground motions in the near-fault region. Soil Dynamics and Earthquake Engineering 24, 815-828.

Carr M. J., Feigenson M. D., Patino L. C., Walker J. A., 2003. Volcanism and geochemistry in Central America: progress and problems. Geophysical Monograph 138, 153-174.

Carr M. J., Stoiber R. E., 1977. Geologic setting of some destructive earthquakes in Central America. Geol. Soc. of America Bull. 88, 151-156.

Cembrano J., Lara L., 2009. The link between volcanism and tectonics in the southern volcanic zone of the Chilean Andes: A review. Tectonophysics 471, 96113.

Corazzato C., Tibaldi A., 2006. Fracture control on type, morphology and distribution of parasitic volcanic cones: An example from Mt. Etna, Italy. Journal of Volcanology and Geothermal Reserach 158, 177-194. 
Delle Donne D., Harris A., Ripepe M., Wright R., 2010. Earthquake-induced thermal anomalies at active volcanoes. Geology 38, 771-774.

DeMets C., 2001. A new estimate for present-day Cocos-Caribbean plate motion: implications for slip along the Central American volcanic arc. Geophysical Research Letters 28, 4043-4046.

Dixon T. H., 2013. Detailed data available for recent Costa Rica earthquake. EOS 94, 17-18.

Eggert S., Walter T. R., 2009. Volcanic activity before and after large tectonic earthquakes: Observations and statistical significance. Tectonophysics 471, 14-26.

Herrmann R. B., 2002. Computer Program in Seismology v 3.3.

Hill D. P., 2008. Dynamic stresses, Coulomb failure, and remote triggering. Bull. of the Seism. Soc. of America 98, 66-92.

Hill D. P., Pollitz F., Newhall C., 2002. Earthquake-volcano interactions. Physics Today, 42-47.

Ichihara M. and Brodsky E. E., 2006. A limit on the effect of rectified diffusion in volcanic systems. Geophys. Res. Lett. 32, L02316.

Ji C., D.J. Wald, and D.V. Helmberger, 2002. Source description of the 1999 Hector Mine, California earthquake; Part I: Wavelet domain inversion theory and resolution analysis. Bull. Seism. Soc. Am., 92, 1192-1207.

Kennett B. L. N., Engdahl E. R. and Buland R. 1995. "Constraints on seismic velocities in the earth from travel times" Geophys. J. Int. 122:108-124.

King G. C. P., Stein R. S., Lin J., 1994. Static stress change and the triggering of earthquakes. Bull. of the Seism. Soc. of America 84, 935-953.

Leeman W., Carr M. J., Morris J. D., 1993. Boron geochemistry of the Central American Volcanic Arc: constraints on the genesis of subduction-related magmas. Geochimica et Cosmochimica Acta 58, 149-168.

Lin, J. and R.S. Stein, 2004, Stress triggering in thrust and subduction earthquakes, and stress interaction between the southern San Andreas and nearby thrust and strike-slip faults. Journal of Geophysical Research 109, B02303.

Linde A. T., Sacks I. S., 1998. Triggering of volcanic eruptions. Letters to Nature 395, 888-890. 
MacMillan I., Gans P. B., Alvarado G., 2004. Middle Miocene to present plate tectonic history of the southern Central American Volcanic Arc. Tectonophysics 392, 325-348.

Manga M., Brodsky E., 2006. Seismic triggering of eruptions in the far field: volcanoes and geysers. Annu. Rev. Earth Planet. Sci. 34, 263-291.

Marzocchi W., 2002. Remote sensing influence on large explosive eruptions. Journal of Geophysical Research 107.

Motazedian D., Atkinson G. M., 2005. Stochastic finite-fault modeling based on dynamic corner frequency. Bull. of the Seism. Soc. of America 95, 995-1010.

Nakamura K., 1977. Volcanoes as possible indicators of tectonics stress orientation, principal and proposal. Journal of Volcanology and Geothermal Research 2, 1-16.

Protti M., McNally K., Pacheco J., Gonzalez V., Montero C., Segura J., Brenes J., Barboza V., Malavassi E., Guendel F., Simila G., Rojas D., Velasco A., Mata A., Schillinger W., 1995. The March 25, $1990\left(M_{W}=7.0, M_{L}=6.8\right)$, earthquake at the entrance of the Nicoya Gulf, Costa Rica: its prior acivity, foreshocks, aftershocks, and triggered seismicity. Journal of Geophysical Reserach 100, 20345-20358.

Quintero, R. and Güendel, F., 2000. Stress Field in Costa Rica, Central America. Journal of Seismology 4(3), 297-319.

Red Seismológical Nacional UCR-ICE, 2012. L. Linkimer and G. J. Soto. El Terremoto de Sámara del 5 de setiembre del 2012.

Red Seismológical Nacional UCR-ICE, 2013. R. B. Picado, W. R. Quesada, R. MoraAmador, A. V. Villalobos. Informe anual sismos sentidos y actividad volcanica 2012.

Rinehart J. S., 1972. Fluctuations in geyser activity caused by variations in Earth tidal forces, barometric pressure, and tectonic stresses. J. Geophys. Res. 77, 342-50

Rose W. I., Conway F. M., Pullinger C. R., Deino A., McIntosh W. C., 1999. An improved age framework for late Quaternary silicic eruptions in norther Central America. Bull. Volcanol. 61, 106-120.

Smithsonian Institution Global Volcanism Program. May 2014. http://www.volcano.si.edu/ 
Somerville P. G., 2003. Magnitude scaling of the near fault rupture directivity pulse. Physics of the Earth and Planet. Interiors 137, 201-212.

Stein S., Wysession M. An introduction to seismology, earthquakes, and earth structure. Blackwell Publishing, 2003. Print.

Stoiber R. E., Carr M. J., 1973. QUaternary volcanic and tectonic segmentation of Central America. Bull. Volcanol. 37, 304-325.

Toda, S., R. S. Stein, K. Richards-Dinger and S. Bozkurt, 2005, Forecasting the evolution of seismicity in southern California: Animations built on earthquake stress transfer. Journal of Geophysical Research 110, B05S16.

USGS Earthquake Hazard Program. M 7.6 - Costa Rica. May 2014. http://comcat.cr.usgs.gov/earthquakes/eventpage/pde20120905144207800_35\# summary

Velasco A., Ammon C. J., Farrell J., Pankow K., 2004. Rupture directivity of the 3 November 2002 Denali Fault earthquake determined from surface waves. Bull. of the Seism. Soc. of America 94, S293-S299.

Velasco A., Hernandez S., Parsons T., Pankow K., 2008. Global ubiquity of dynamic earthquake triggering. Nature geoscience 1, 375-379.

Walter T. R., Wang R., Acocella V., Neri M., Grosser H., Zschau J., 2009.

Simultaneous magma and gas eruptions at three volcanoes in southern Italy: An earthquake trigger?. Geology 37, 251-254.

Walter T. R., Wang R., Zimmer M., Grosser H., Luhr B., Ratdompurbo A., 2007. Volcanic activity influenced by tectonic earthquakes: Static and dynamic stress triggering at Mt. Merapi. Geophysical Research Letters 34, L05304.

Watt S. F. L., Pyle D. M., Mather T. A., 2009. The influence of great earthquakes on volcanic eruption rate along the Chilean subduction zone. Earth and Planet. Science Letters 277, 399-4.7. 


\section{Acknowledgements}

First of all, I would like to thank my advisor, Greg Waite, whom during the course of these two years greatly helped me to develop this Master's thesis and, in general, my knowledge in the topics of volcanology and seismology, always putting great enthusiasm in the process. He has always been very kind, professional, helpful and available. Patience is surely another of his numerous qualities. Thanks Greg, I hope we'll keep in touch in some way.

I then would like to thank Rüdiger Escobar Wolf, currently a postdoc at MTU, who had always lent me a hand when I encountered problems in MATLAB and other softwares. Rüdi is good people, and surely a gold mine of information and volcanological knowledge.

Great help for some MATLAB codes have been given me also by Kyle Brill.

I would like to thank and give a big hug to Christine Sealing, my girlfriend, for the first reading, review and useful grammar check of most of this written document. Thanks for being close to me and having pushed me when I needed to be pushed.

On a different topic, thanks to Benjamin van Wyk de Vries, William I. Rose, Simon Carn, Alessandro Tibaldi and many others to have put the effort and made the INVOGE program and thus, this increadible experience of mine, possible. Experiences like this one are great, very valuable and always worth it. 
Finally, thanks to my family, for the emotional and economical support during this two years of INVOGE program, during which they patiently endured having me far away. Far or close, I love you all, very much.

A big hug also to all those old and new friends who I left home and made here in Michigan. When you travel, people come and go, and some are greatly missed, but in any case, each one of you made a big difference in my path. Thanks and hope to see y'all soon again $=$ )

Houghton, MI, U.S.A.

12 June 2014

Lorenzo 


\section{Appendix A}

Table A.1 - Physical and petrological parameters for the 27 volcanoes taken into account during this study. N/A = not available, unkn = unknown. Sources: (1) Smithsonian Institution Global Volcanism Program, (2) Carr et al., 2003

\begin{tabular}{|c|c|c|c|c|c|c|c|c|}
\hline Volcano & $\begin{array}{l}\text { Lat/lo } \\
\mathrm{ng}\left({ }^{\circ}\right)\end{array}$ & $\begin{array}{c}\text { Distan } \\
\text { ce } \\
\text { from } \\
\text { epicen } \\
\text { ter } \\
(\mathrm{km})\end{array}$ & $\begin{array}{l}\text { Azimu } \\
\text { th } \\
\text { from } \\
\text { epicen } \\
\text { ter }\left(^{\circ}\right)\end{array}$ & Type ${ }^{(1)}$ & $\begin{array}{c}\text { Volu } \\
\text { me } \\
\left(\mathrm{km}^{3}\right) \\
(2)\end{array}$ & $\begin{array}{l}\text { Domina } \\
\text { nt rock } \\
\text { type }{ }^{(1)}\end{array}$ & $\begin{array}{l}\text { Last } \\
\text { erupti } \\
\text { on }^{(1)}\end{array}$ & $\begin{array}{c}\text { Countr } \\
y\end{array}$ \\
\hline $\begin{array}{c}\text { Cosigüin } \\
\quad \mathrm{a}\end{array}$ & $\begin{array}{c}12.98 \\
/ \\
- \\
87.57\end{array}$ & $\begin{array}{c}404.5 \\
3\end{array}$ & $\begin{array}{c}322.4 \\
7\end{array}$ & $\begin{array}{c}\text { Stratovol } \\
\text { cano }\end{array}$ & 33 & $\begin{array}{l}\text { Basaltic } \\
\text { andesite }\end{array}$ & 1859 & $\begin{array}{c}\text { Nicara } \\
\text { gua }\end{array}$ \\
\hline $\begin{array}{c}\text { San } \\
\text { Cristóbal }\end{array}$ & $\begin{array}{c}12.70 \\
/ \\
- \\
87.00\end{array}$ & $\begin{array}{c}343.2 \\
4\end{array}$ & $\begin{array}{c}327.6 \\
4\end{array}$ & $\begin{array}{c}\text { Stratovol } \\
\text { cano }\end{array}$ & 65 & Basalt & 2013 & $\begin{array}{c}\text { Nicara } \\
\text { gua }\end{array}$ \\
\hline Telica & $\begin{array}{c}12.60 \\
/ \\
- \\
86.85\end{array}$ & $\begin{array}{c}324.3 \\
6\end{array}$ & $\begin{array}{c}329.0 \\
7\end{array}$ & $\begin{array}{c}\text { Stratovol } \\
\text { cano }\end{array}$ & 28 & Basalt & 2011 & $\begin{array}{c}\text { Nicara } \\
\text { gua }\end{array}$ \\
\hline Rota & $\begin{array}{c}12.55 \\
/ \\
- \\
86.75\end{array}$ & $\begin{array}{c}314.4 \\
5\end{array}$ & $\begin{array}{c}330.1 \\
1\end{array}$ & $\begin{array}{c}\text { Stratovol } \\
\text { cano }\end{array}$ & 12 & $\begin{array}{l}\text { Basaltic } \\
\text { andesite }\end{array}$ & unkn & $\begin{array}{c}\text { Nicara } \\
\text { gua }\end{array}$ \\
\hline Volcan & 12.53 & 311.1 & 29.7 & Cinder & N/A & Trachyb & unkn & Nicara \\
\hline
\end{tabular}




\begin{tabular}{|c|c|c|c|c|c|c|c|c|}
\hline Azul & $\begin{array}{c}1 \\
- \\
83.87\end{array}$ & 2 & & cones & & asalt & & gua \\
\hline $\begin{array}{l}\text { Cerro } \\
\text { Negro }\end{array}$ & $\begin{array}{c}12.50 \\
/ \\
- \\
86.70\end{array}$ & $\begin{array}{c}307.1 \\
5\end{array}$ & $\begin{array}{c}330.3 \\
7\end{array}$ & $\begin{array}{l}\text { Cinder } \\
\text { cones }\end{array}$ & $<1$ & Basalt & 1999 & $\begin{array}{c}\text { Nicara } \\
\text { gua }\end{array}$ \\
\hline Las Pilas & $\begin{array}{c}12.50 \\
/ \\
- \\
86.68\end{array}$ & $\begin{array}{c}305.8 \\
8\end{array}$ & 330.8 & Complex & 14 & $\begin{array}{l}\text { Basaltic } \\
\text { andesite }\end{array}$ & 1954 & $\begin{array}{c}\text { Nlcara } \\
\text { gua }\end{array}$ \\
\hline $\begin{array}{c}\text { Momoto } \\
\text { mbo }\end{array}$ & $\begin{array}{c}12.42 \\
/ \\
- \\
86.53\end{array}$ & $\begin{array}{c}290.1 \\
3\end{array}$ & $\begin{array}{c}332.5 \\
9\end{array}$ & $\begin{array}{c}\text { Stratovol } \\
\text { cano }\end{array}$ & 18 & Basalt & 1905 & $\begin{array}{c}\text { Nicara } \\
\text { gua }\end{array}$ \\
\hline $\begin{array}{c}\text { Apoyequ } \\
\mathrm{e}\end{array}$ & $\begin{array}{c}12.25 \\
/ \\
- \\
86.33\end{array}$ & $\begin{array}{c}263.6 \\
8\end{array}$ & $\begin{array}{c}334.7 \\
6\end{array}$ & $\begin{array}{l}\text { Pyroclasti } \\
\text { c shield }\end{array}$ & 6 & Dacite & $50 \mathrm{BC}$ & $\begin{array}{c}\text { Nicara } \\
\text { gua }\end{array}$ \\
\hline $\begin{array}{l}\text { Nejapa- } \\
\text { Miraflore } \\
\text { s }\end{array}$ & $\begin{array}{c}12.11 \\
/ \\
- \\
86.32\end{array}$ & $\begin{array}{c}249.8 \\
4\end{array}$ & $\begin{array}{c}333.9 \\
3\end{array}$ & $\begin{array}{l}\text { Fissure } \\
\text { vents }\end{array}$ & 3 & Basalt & 1060 & $\begin{array}{c}\text { Nicara } \\
\text { gua }\end{array}$ \\
\hline Masaya & $\begin{array}{c}11.98 \\
/ \\
- \\
86.15\end{array}$ & $\begin{array}{c}229.3 \\
8\end{array}$ & $\begin{array}{c}335.9 \\
5\end{array}$ & Caldera & 168 & Basalt & 2008 & $\begin{array}{c}\text { Nicara } \\
\text { gua }\end{array}$ \\
\hline
\end{tabular}




\begin{tabular}{|c|c|c|c|c|c|c|c|c|}
\hline Granada & $\begin{array}{c}11.88 \\
/ \\
- \\
86.00\end{array}$ & $\begin{array}{c}215.6 \\
8\end{array}$ & $\begin{array}{c}339.8 \\
4\end{array}$ & $\begin{array}{c}\text { Fissure } \\
\text { vents }\end{array}$ & 1 & Basalt & unkn & $\begin{array}{c}\text { Nicara } \\
\text { gua }\end{array}$ \\
\hline $\begin{array}{c}\text { Mombac } \\
\text { ho }\end{array}$ & $\begin{array}{c}11.83 \\
/ \\
- \\
85.98\end{array}$ & $\begin{array}{c}204.6 \\
8\end{array}$ & $\begin{array}{c}339.4 \\
4\end{array}$ & $\begin{array}{c}\text { Stratovol } \\
\text { cano }\end{array}$ & 19 & $\begin{array}{l}\text { Basaltic } \\
\text { andesite }\end{array}$ & unkn & $\begin{array}{c}\text { Nicara } \\
\text { gua }\end{array}$ \\
\hline Zapatera & $\begin{array}{c}11.74 \\
/ \\
- \\
85.84\end{array}$ & $\begin{array}{c}189.9 \\
4\end{array}$ & $\begin{array}{c}342.9 \\
1\end{array}$ & Shield & 5 & $\begin{array}{l}\text { Basaltic } \\
\text { andesite }\end{array}$ & unkn & $\begin{array}{c}\text { Nicara } \\
\text { gua }\end{array}$ \\
\hline $\begin{array}{c}\text { Concepti } \\
\text { ón }\end{array}$ & $\begin{array}{c}11.53 \\
/ \\
- \\
85.62\end{array}$ & $\begin{array}{c}164.0 \\
6\end{array}$ & $\begin{array}{c}347.7 \\
6\end{array}$ & $\begin{array}{c}\text { Stratovol } \\
\text { cano }\end{array}$ & 19 & $\begin{array}{l}\text { Basaltic } \\
\text { andesite }\end{array}$ & 2011 & $\begin{array}{c}\text { Nicara } \\
\text { gua }\end{array}$ \\
\hline Maderas & $\begin{array}{c}11.42 \\
/ \\
- \\
85.50\end{array}$ & $\begin{array}{c}164.0 \\
6\end{array}$ & $\begin{array}{c}351.3 \\
2\end{array}$ & $\begin{array}{c}\text { Stratovol } \\
\text { cano }\end{array}$ & 22 & $\begin{array}{l}\text { Basaltic } \\
\text { andesite }\end{array}$ & unkn & $\begin{array}{c}\text { Nicara } \\
\text { gua }\end{array}$ \\
\hline $\begin{array}{l}\text { Rincón } \\
\text { de la } \\
\text { Vieja }\end{array}$ & $\begin{array}{c}10.83 \\
/ \\
- \\
85.33\end{array}$ & 82.19 & $\begin{array}{c}358.4 \\
7\end{array}$ & Complex & 201 & $\begin{array}{l}\text { Basaltic } \\
\text { andesite }\end{array}$ & 2012 & $\begin{array}{c}\text { Costa } \\
\text { Rica }\end{array}$ \\
\hline $\begin{array}{c}\text { Miravalle } \\
\text { s }\end{array}$ & $\begin{array}{c}10.75 \\
/ \\
-\end{array}$ & 74.91 & 12.61 & $\begin{array}{c}\text { Stratovol } \\
\text { cano }\end{array}$ & 132 & $\begin{array}{l}\text { Basaltic } \\
\text { andesite }\end{array}$ & 1946 & $\begin{array}{c}\text { Costa } \\
\text { Rica }\end{array}$ \\
\hline
\end{tabular}




\begin{tabular}{|c|c|c|c|c|c|c|c|c|}
\hline & 85.15 & & & & & & & \\
\hline Tenorio & $\begin{array}{c}10.67 \\
/ \\
- \\
85.02\end{array}$ & 72.16 & 25.87 & $\begin{array}{c}\text { Stratovol } \\
\text { cano }\end{array}$ & 95 & $\begin{array}{l}\text { Basaltic } \\
\text { andesite }\end{array}$ & unkn & $\begin{array}{r}\text { Costa } \\
\text { Rica }\end{array}$ \\
\hline Arenal & $\begin{array}{c}10.47 \\
/ \\
- \\
84.73\end{array}$ & 77.82 & 57.57 & $\begin{array}{c}\text { Stratovol } \\
\text { cano }\end{array}$ & 13 & $\begin{array}{l}\text { Basaltic } \\
\text { andesite }\end{array}$ & 2010 & $\begin{array}{l}\text { Costa } \\
\text { Rica }\end{array}$ \\
\hline Platanar & $\begin{array}{c}10.30 \\
/ \\
- \\
84.37\end{array}$ & $\begin{array}{c}105.4 \\
3\end{array}$ & 77.21 & $\begin{array}{c}\text { Stratovol } \\
\text { cano }\end{array}$ & 32 & $\begin{array}{l}\text { Basaltic } \\
\text { andesite }\end{array}$ & unkn & $\begin{array}{r}\text { Costa } \\
\text { Rica }\end{array}$ \\
\hline Poás & $\begin{array}{c}10.20 \\
/ \\
- \\
84.22\end{array}$ & $\begin{array}{c}117.9 \\
8\end{array}$ & 84.04 & $\begin{array}{c}\text { Stratovol } \\
\text { cano }\end{array}$ & 168 & $\begin{array}{l}\text { Basaltic } \\
\text { andesite }\end{array}$ & 2013 & $\begin{array}{l}\text { Costa } \\
\text { Rica }\end{array}$ \\
\hline Barva & $\begin{array}{c}10.13 \\
/ \\
- \\
84.08\end{array}$ & $\begin{array}{c}131.9 \\
2\end{array}$ & 87.69 & Complex & 326 & $\begin{array}{l}\text { Basaltic } \\
\text { andesite }\end{array}$ & $\begin{array}{c}6050 \\
\text { BC }\end{array}$ & $\begin{array}{l}\text { Costa } \\
\text { Rica }\end{array}$ \\
\hline Turrialba & $\begin{array}{c}10.03 \\
/ \\
- \\
83.77\end{array}$ & $\begin{array}{c}168.3 \\
6\end{array}$ & 92.41 & $\begin{array}{c}\text { Stratovol } \\
\text { cano }\end{array}$ & 151 & $\begin{array}{l}\text { Basaltic } \\
\text { andesite }\end{array}$ & 2013 & $\begin{array}{l}\text { Costa } \\
\text { Rica }\end{array}$ \\
\hline Irazú & $\begin{array}{c}9.98 / \\
-\end{array}$ & $\begin{array}{c}159.1 \\
6\end{array}$ & 94.32 & $\begin{array}{c}\text { Stratovol } \\
\text { cano }\end{array}$ & 227 & $\begin{array}{l}\text { Basaltic } \\
\text { andesite }\end{array}$ & 1994 & Costa \\
\hline
\end{tabular}




\begin{tabular}{|c|c|c|c|c|c|c|c|c|}
\hline & 83.85 & & & & & & & Rica \\
\hline Barú & $\begin{array}{c}8.80 / \\
- \\
82.54\end{array}$ & $\begin{array}{c}334.5 \\
9\end{array}$ & $\begin{array}{c}115.0 \\
1\end{array}$ & $\begin{array}{c}\text { Stratovol } \\
\text { cano }\end{array}$ & N/A & $\begin{array}{l}\text { Basaltic } \\
\text { andesite }\end{array}$ & 1550 & $\begin{array}{c}\text { Panam } \\
\text { a }\end{array}$ \\
\hline
\end{tabular}




\section{Appendix B}

Table B.1 - Signs of activity after the Mw 7.6 Nicoya earthquake of 5th September 2012 at the 27 volcanoes analyzed. All the information are taken from the Smithsonian Institution Global Volcanism Program. Information updated at 05/15/2014.

\begin{tabular}{|c|c|c|c|c|}
\hline Volcano & $\begin{array}{l}\text { Signs of } \\
\text { unrest }\end{array}$ & Type of unrest (if present) & $\begin{array}{l}\text { Dates } \\
\text { of } \\
\text { unrest } \\
\text { (if } \\
\text { present } \\
\text { ) }\end{array}$ & $\begin{array}{l}\text { Last date } \\
\text { of unrest } \\
\text { before } \\
\text { earthquak } \\
\text { e of } \\
09 / 05 / 201 \\
2\end{array}$ \\
\hline Tenorio & Yes & Seismicity & $\begin{array}{l}\text { Sept. } \\
2012\end{array}$ & unkn \\
\hline Miravalles & NA & & & unkn \\
\hline Arenal & Yes & $\begin{array}{c}\text { Non-eruptive volcanic } \\
\text { activity }\end{array}$ & $\begin{array}{l}4-10 \\
\text { Sept. } \\
2013\end{array}$ & $\begin{array}{c}\text { August } \\
2011\end{array}$ \\
\hline $\begin{array}{c}\text { Rincón de la } \\
\text { Vieja }\end{array}$ & Yes & $\begin{array}{c}\text { Non-eruptive volcanic } \\
\text { activity }\end{array}$ & $\begin{array}{c}27 \text { Feb. } \\
-5 \text { Mar. } \\
2013\end{array}$ & April 2012 \\
\hline Orosí & NA & & & unkn \\
\hline Platanar & NA & & & unkn \\
\hline Poás & Yes & Eruption & $\begin{array}{c}24-30 \\
\text { Oct. } \\
2012 \\
29 \text { May } \\
\text { - } 4 \text { Jun. } \\
2013 \\
26 \text { Feb. } \\
\text { - } 4 \text { Mar. } \\
2014 \\
26 \text { Mar. } \\
\text { - 1 Apr. } \\
2014 \\
\end{array}$ & June 2012 \\
\hline Barva & No/NA & & & unkn \\
\hline Maderas & $\mathrm{No} / \mathrm{NA}$ & & & unkn \\
\hline Irazú & Yes & Seismicity & & unkn \\
\hline Concepción & No & & & $\begin{array}{c}\text { March } \\
2010\end{array}$ \\
\hline
\end{tabular}




\begin{tabular}{|c|c|c|c|c|}
\hline Turrialba & Yes & $\begin{array}{l}\text { Non-eruptive volcanic } \\
\text { activity }\end{array}$ & $\begin{array}{c}29 \text { May } \\
-4 \text { June } \\
2013 \\
17-23 \\
\text { July } \\
2013\end{array}$ & $\begin{array}{c}\text { February } \\
2012\end{array}$ \\
\hline Zapatera & NA & & & unkn \\
\hline Mombacho & NA & & & unkn \\
\hline Granada & NA & & & unkn \\
\hline Masaya & No & & & $\begin{array}{c}\text { December } \\
2008 \\
\end{array}$ \\
\hline $\begin{array}{c}\text { Nejapa- } \\
\text { Miraflores }\end{array}$ & NA & & & unkn \\
\hline Apoyeque & Yes & Seismicity & $\begin{array}{l}\text { 05-11 } \\
\text { Sept. } \\
2012\end{array}$ & unkn \\
\hline Momotombo & NA & & & unkn \\
\hline Las Pilas & NA & & & unkn \\
\hline Cerro Negro & Yes & Seismicity & $\begin{array}{l}5-11 \\
\text { June } \\
2013\end{array}$ & unkn \\
\hline Volcan Azul & NA & & & unkn \\
\hline Rota & NA & & & unkn \\
\hline Telica & Yes & Eruption & $\begin{array}{l}\text { 12-18 } \\
\text { Sept. } \\
2012\end{array}$ & May 2011 \\
\hline Barú & NA & & & unkn \\
\hline San Cristóbal & Yes & Eruption & $\begin{array}{c}\text { 12-18 } \\
\text { Sept. } \\
2012 \\
19 \text { Dec. } \\
2012 \text { - } \\
01 \text { Jan. } \\
2013 \\
05-11 \\
\text { Jun. } \\
2013 \\
5-11 \\
\text { Feb. } \\
2014\end{array}$ & $\begin{array}{l}\text { August } \\
2011\end{array}$ \\
\hline
\end{tabular}




\begin{tabular}{|c|c|l|c|c|}
\hline & & & $09-15$ & \\
& & & Apr. \\
2014 & \\
\hline Cosigüina & NA & & & unkn \\
\hline
\end{tabular}




\section{Appendix C}

Table C.1 - Numerical results for the static stress change analysis. In the sixth column are listed the values of change in normal stress (in $\mathrm{MPa}$ ) for the 10 values of strike for each volcano. All the calculations have been done at $3 \mathrm{~km}$ of depth. The values highlighted in the table are those relative to the minimum value of change in normal stress and their relative strike (bold), the maximum changes in stress and their values (italics) and the values of change in stress relative to the strike parallel and orthogonal to the direction of the Middle American Trench (underlined). The volcanoes are listed in increasing distance from the earthquake epicenter.

\begin{tabular}{|c|c|c|c|c|c|}
\hline \multirow[b]{2}{*}{ Volcano } & \multirow[b]{2}{*}{$\begin{array}{c}\text { Distance } \\
(\mathrm{km})\end{array}$} & \multicolumn{3}{|c|}{ Receiving fault geometry } & \multirow{2}{*}{$\begin{array}{c}\text { Normal } \\
\text { Static } \\
\text { Stress } \\
\text { Change } \\
\text { (MPa) }\end{array}$} \\
\hline & & Rake $\left({ }^{\circ}\right)$ & Strike $\left({ }^{\circ}\right)$ & $\operatorname{Dip}\left({ }^{\circ}\right)$ & \\
\hline \multirow{10}{*}{ Tenorio } & \multirow{10}{*}{72.16} & \multirow{10}{*}{-90} & 22.5 & \multirow{10}{*}{90} & -0.0352 \\
\hline & & & 45 & & -0.0238 \\
\hline & & & 67.5 & & 0.003 \\
\hline & & & 90 & & 0.0296 \\
\hline & & & 112.5 & & 0.0402 \\
\hline & & & 135 & & 0.0288 \\
\hline & & & 157.5 & & 0.002 \\
\hline & & & 180 & & -0.0245 \\
\hline & & & $\underline{125}$ & & 0.0365 \\
\hline & & & $\underline{35}$ & & -0.0314 \\
\hline \multirow{10}{*}{ Miravalles } & \multirow{10}{*}{74.91} & \multirow{10}{*}{-90} & 22.5 & \multirow{10}{*}{90} & -0.0325 \\
\hline & & & 45 & & -0.0094 \\
\hline & & & 67.5 & & 0.0196 \\
\hline & & & 90 & & 0.0374 \\
\hline & & & 112.5 & & 0.0337 \\
\hline & & & 135 & & 0.0106 \\
\hline & & & 157.5 & & -0.0184 \\
\hline & & & 180 & & -0.0362 \\
\hline & & & 125 & & 0.0226 \\
\hline & & & $\underline{35}$ & & -0.0214 \\
\hline \multirow{6}{*}{ Arenal } & \multirow{6}{*}{77.82} & \multirow{6}{*}{-90} & 22.5 & \multirow{6}{*}{90} & -0.0097 \\
\hline & & & 45 & & -0.0334 \\
\hline & & & 67.5 & & -0.0382 \\
\hline & & & 90 & & -0.0213 \\
\hline & & & 112.5 & & 0.0074 \\
\hline & & & 135 & & 0.031 \\
\hline
\end{tabular}




\begin{tabular}{|c|c|c|c|c|c|}
\hline & & & 157.5 & & 0.0359 \\
\hline & & & 180 & & 0.019 \\
\hline & & & 125 & & 0.0222 \\
\hline & & & $\underline{35}$ & & -0.0245 \\
\hline \multirow{10}{*}{ Rincón de la Vieja } & \multirow{10}{*}{82.19} & \multirow{10}{*}{-90} & 22.5 & \multirow{10}{*}{90} & -0.0181 \\
\hline & & & 45 & & 0.0104 \\
\hline & & & 67.5 & & 0.0329 \\
\hline & & & 90 & & 0.0362 \\
\hline & & & 112.5 & & 0.0184 \\
\hline & & & 135 & & -0.0101 \\
\hline & & & 157.5 & & -0.0326 \\
\hline & & & 180 & & -0.0359 \\
\hline & & & $\underline{125}$ & & $\underline{0.0029}$ \\
\hline & & & $\underline{35}$ & & $\underline{-0.0026}$ \\
\hline \multirow{10}{*}{ Orosí } & \multirow{10}{*}{100.37} & \multirow{10}{*}{-90} & 22.5 & \multirow{10}{*}{90} & 0.0041 \\
\hline & & & 45 & & 0.0253 \\
\hline & & & 67.5 & & 0.0347 \\
\hline & & & 90 & & 0.0269 \\
\hline & & & 112.5 & & 0.0064 \\
\hline & & & 135 & & -0.0147 \\
\hline & & & 157.5 & & -0.0241 \\
\hline & & & 180 & & -0.0163 \\
\hline & & & 125 & & -0.0061 \\
\hline & & & 35 & & 0.0167 \\
\hline \multirow{10}{*}{ Platanar } & \multirow{10}{*}{105.43} & \multirow{10}{*}{-90} & 22.5 & \multirow{10}{*}{90} & 0.0245 \\
\hline & & & 45 & & 0.004 \\
\hline & & & 67.5 & & -0.017 \\
\hline & & & 90 & & -0.026 \\
\hline & & & 112.5 & & -0.0178 \\
\hline & & & 135 & & 0.0028 \\
\hline & & & 157.5 & & 0.0237 \\
\hline & & & 180 & & 0.0327 \\
\hline & & & $\underline{125}$ & & -0.0072 \\
\hline & & & $\underline{35}$ & & 0.0139 \\
\hline \multirow{4}{*}{ Poás } & \multirow{4}{*}{117.98} & \multirow{4}{*}{-90} & 22.5 & \multirow{4}{*}{90} & 0.0242 \\
\hline & & & 45 & & 0.0139 \\
\hline & & & 67.5 & & -0.0024 \\
\hline & & & 90 & & -0.0153 \\
\hline
\end{tabular}




\begin{tabular}{|c|c|c|c|c|c|}
\hline & & & 112.5 & & -0.0171 \\
\hline & & & 135 & & -0.0069 \\
\hline & & & 157.5 & & 0.0094 \\
\hline & & & 180 & & 0.0223 \\
\hline & & & $\underline{125}$ & & $\underline{-0.0127}$ \\
\hline & & & $\underline{35}$ & & $\underline{0.0197}$ \\
\hline \multirow{10}{*}{ Barva } & \multirow{10}{*}{131.92} & \multirow{10}{*}{-90} & 22.5 & \multirow{10}{*}{90} & 0.0169 \\
\hline & & & 45 & & 0.0129 \\
\hline & & & 67.5 & & 0.0025 \\
\hline & & & 90 & & -0.008 \\
\hline & & & 112.5 & & -0.0127 \\
\hline & & & 135 & & -0.0087 \\
\hline & & & 157.5 & & 0.0016 \\
\hline & & & 180 & & 0.0122 \\
\hline & & & $\underline{125}$ & & $\underline{-0.0115}$ \\
\hline & & & $\underline{35}$ & & $\underline{0.0157}$ \\
\hline \multirow{10}{*}{ Maderas } & \multirow{10}{*}{152.05} & \multirow{10}{*}{-90} & 22.5 & \multirow{10}{*}{90} & 0.0044 \\
\hline & & & 45 & & 0.0144 \\
\hline & & & 67.5 & & 0.0191 \\
\hline & & & 90 & & 0.0157 \\
\hline & & & 112.5 & & 0.0062 \\
\hline & & & 135 & & -0.0038 \\
\hline & & & 157.5 & & -0.0085 \\
\hline & & & 180 & & -0.0051 \\
\hline & & & $\underline{125}$ & & 0.0003 \\
\hline & & & $\underline{35}$ & & 0.0104 \\
\hline \multirow{10}{*}{ Irazú } & \multirow{10}{*}{159.16} & \multirow{10}{*}{-90} & 22.5 & \multirow{10}{*}{90} & 0.0049 \\
\hline & & & 45 & & 0.0058 \\
\hline & & & 67.5 & & 0.0029 \\
\hline & & & 90 & & -0.0021 \\
\hline & & & 112.5 & & -0.0063 \\
\hline & & & 135 & & -0.0072 \\
\hline & & & 157.5 & & -0.0043 \\
\hline & & & 180 & & 0.0007 \\
\hline & & & 125 & & -0.0073 \\
\hline & & & 35 & & 0.0059 \\
\hline \multirow{2}{*}{ Concepción } & \multirow{2}{*}{164.06} & \multirow{2}{*}{-90} & 22.5 & \multirow{2}{*}{90} & 0.0054 \\
\hline & & & 45 & & 0.0123 \\
\hline
\end{tabular}




\begin{tabular}{|c|c|c|c|c|c|}
\hline & & & 67.5 & & 0.0142 \\
\hline & & & 90 & & 0.0102 \\
\hline & & & 112.5 & & 0.0027 \\
\hline & & & 135 & & -0.0043 \\
\hline & & & 157.5 & & -0.0063 \\
\hline & & & 180 & & -0.0023 \\
\hline & & & 125 & & -0.0017 \\
\hline & & & $\underline{35}$ & & 0.0096 \\
\hline \multirow{10}{*}{ Turrialba } & \multirow{10}{*}{168.36} & \multirow{10}{*}{-90} & 22.5 & \multirow{10}{*}{90} & 0.0056 \\
\hline & & & 45 & & 0.0055 \\
\hline & & & 67.5 & & 0.0021 \\
\hline & & & 90 & & -0.0025 \\
\hline & & & 112.5 & & -0.0058 \\
\hline & & & 135 & & -0.0057 \\
\hline & & & 157.5 & & -0.0023 \\
\hline & & & 180 & & 0.0023 \\
\hline & & & 125 & & -0.0062 \\
\hline & & & 35 & & 0.006 \\
\hline \multirow{10}{*}{ Zapatera } & \multirow{10}{*}{189.94} & \multirow{10}{*}{-90} & 22.5 & \multirow{10}{*}{90} & 0.0044 \\
\hline & & & 45 & & 0.0075 \\
\hline & & & 67.5 & & 0.0074 \\
\hline & & & 90 & & 0.0042 \\
\hline & & & 112.5 & & -0.0002 \\
\hline & & & 135 & & -0.0033 \\
\hline & & & 157.5 & & -0.0033 \\
\hline & & & 180 & & -0.0001 \\
\hline & & & $\underline{125}$ & & -0.0023 \\
\hline & & & $\underline{35}$ & & 0.0064 \\
\hline \multirow{10}{*}{ Mombacho } & \multirow{10}{*}{204.68} & \multirow{10}{*}{-90} & 22.5 & \multirow{10}{*}{90} & 0.0035 \\
\hline & & & 45 & & 0.0052 \\
\hline & & & 67.5 & & 0.0046 \\
\hline & & & 90 & & 0.0021 \\
\hline & & & 112.5 & & -0.001 \\
\hline & & & 135 & & -0.0028 \\
\hline & & & 157.5 & & -0.0022 \\
\hline & & & 180 & & 0.0004 \\
\hline & & & 125 & & -0.0022 \\
\hline & & & 35 & & 0.0047 \\
\hline
\end{tabular}




\begin{tabular}{|c|c|c|c|c|c|}
\hline \multirow{10}{*}{ Granada } & \multirow{10}{*}{215.68} & \multirow{10}{*}{-90} & 22.5 & \multirow{10}{*}{90} & 0.003 \\
\hline & & & 45 & & 0.0047 \\
\hline & & & 67.5 & & 0.0044 \\
\hline & & & 90 & & 0.0021 \\
\hline & & & 112.5 & & -0.0006 \\
\hline & & & 135 & & -0.0023 \\
\hline & & & 157.5 & & -0.002 \\
\hline & & & 180 & & 0.0003 \\
\hline & & & $\underline{125}$ & & -0.0018 \\
\hline & & & 35 & & $\underline{0.0042}$ \\
\hline \multirow{10}{*}{ Masaya } & \multirow{10}{*}{229.38} & \multirow{10}{*}{-90} & 22.5 & \multirow{10}{*}{90} & 0.0023 \\
\hline & & & 45 & & 0.0031 \\
\hline & & & 67.5 & & 0.0025 \\
\hline & & & 90 & & 0.0007 \\
\hline & & & 112.5 & & -0.0011 \\
\hline & & & 135 & & -0.002 \\
\hline & & & 157.5 & & -0.0013 \\
\hline & & & 180 & & 0.0004 \\
\hline & & & 125 & & -0.0018 \\
\hline & & & $\underline{35}$ & & 0.0029 \\
\hline \multirow{10}{*}{ Nejapa-Miraflores } & \multirow{10}{*}{249.84} & \multirow{10}{*}{-90} & 22.5 & \multirow{10}{*}{90} & 0.0016 \\
\hline & & & 45 & & 0.0021 \\
\hline & & & 67.5 & & 0.0015 \\
\hline & & & 90 & & 0.0002 \\
\hline & & & 112.5 & & -0.001 \\
\hline & & & 135 & & -0.0015 \\
\hline & & & 157.5 & & -0.0009 \\
\hline & & & 180 & & 0.0004 \\
\hline & & & 125 & & -0.0014 \\
\hline & & & $\underline{35}$ & & 0.002 \\
\hline \multirow{8}{*}{ Apoyeque } & \multirow{8}{*}{263.68} & \multirow{8}{*}{-90} & 22.5 & \multirow{8}{*}{90} & 0.0014 \\
\hline & & & 45 & & 0.002 \\
\hline & & & 67.5 & & 0.0015 \\
\hline & & & 90 & & 0.0004 \\
\hline & & & 112.5 & & -0.0008 \\
\hline & & & 135 & & -0.0013 \\
\hline & & & 157.5 & & -0.0009 \\
\hline & & & 180 & & 0.0003 \\
\hline
\end{tabular}




\begin{tabular}{|c|c|c|c|c|c|}
\hline & & & $\underline{125}$ & & -0.0012 \\
\hline & & & 35 & & 0.0018 \\
\hline \multirow{10}{*}{ Momotombo } & \multirow{10}{*}{290.13} & \multirow{10}{*}{-90} & 22.5 & \multirow{10}{*}{90} & 0.001 \\
\hline & & & 45 & & 0.0013 \\
\hline & & & 67.5 & & 0.0009 \\
\hline & & & 90 & & 0.0001 \\
\hline & & & 112.5 & & -0.0007 \\
\hline & & & 135 & & -0.0009 \\
\hline & & & 157.5 & & -0.0006 \\
\hline & & & 180 & & 0.0002 \\
\hline & & & 125 & & -0.0009 \\
\hline & & & $\underline{35}$ & & $\underline{0.0012}$ \\
\hline \multirow{10}{*}{ Las Pilas } & \multirow{10}{*}{305.88} & \multirow{10}{*}{-90} & 22.5 & \multirow{10}{*}{90} & 0.0007 \\
\hline & & & 45 & & 0.0009 \\
\hline & & & 67.5 & & 0.0006 \\
\hline & & & 90 & & -0.0001 \\
\hline & & & 112.5 & & -0.0006 \\
\hline & & & 135 & & -0.0008 \\
\hline & & & 157.5 & & -0.0005 \\
\hline & & & 180 & & 0.0002 \\
\hline & & & 125 & & -0.0008 \\
\hline & & & 35 & & 0.0009 \\
\hline \multirow{10}{*}{ Cerro Negro } & \multirow{10}{*}{307.15} & \multirow{10}{*}{-90} & 22.5 & \multirow{10}{*}{90} & 0.0007 \\
\hline & & & 45 & & 0.0009 \\
\hline & & & 67.5 & & 0.0006 \\
\hline & & & 90 & & -0.0001 \\
\hline & & & 112.5 & & -0.0006 \\
\hline & & & 135 & & -0.0008 \\
\hline & & & 157.5 & & -0.0005 \\
\hline & & & 180 & & 0.0002 \\
\hline & & & 125 & & -0.0008 \\
\hline & & & 35 & & 0.0009 \\
\hline \multirow{6}{*}{ Volcan Azul } & \multirow{6}{*}{311.12} & \multirow{6}{*}{-90} & 22.5 & \multirow{6}{*}{90} & -0.0004 \\
\hline & & & 45 & & -0.0002 \\
\hline & & & 67.5 & & 0.0014 \\
\hline & & & 90 & & 0.0034 \\
\hline & & & 112.5 & & 0.0046 \\
\hline & & & 135 & & 0.0043 \\
\hline
\end{tabular}




\begin{tabular}{|c|c|c|c|c|c|}
\hline & & & 157.5 & & 0.0028 \\
\hline & & & 180 & & 0.0008 \\
\hline & & & 125 & & 0.0047 \\
\hline & & & 35 & & -0.0005 \\
\hline \multirow{10}{*}{ Rota } & \multirow{10}{*}{314.45} & \multirow{10}{*}{-90} & 22.5 & \multirow{10}{*}{90} & 0.0007 \\
\hline & & & 45 & & 0.0008 \\
\hline & & & 67.5 & & 0.0005 \\
\hline & & & 90 & & -0.0001 \\
\hline & & & 112.5 & & -0.0006 \\
\hline & & & 135 & & -0.0007 \\
\hline & & & 157.5 & & -0.0004 \\
\hline & & & 180 & & 0.0002 \\
\hline & & & 125 & & -0.0007 \\
\hline & & & 35 & & 0.0008 \\
\hline \multirow{10}{*}{ Telica } & \multirow{10}{*}{324.36} & \multirow{10}{*}{-90} & 22.5 & \multirow{10}{*}{90} & 0.0006 \\
\hline & & & 45 & & 0.0007 \\
\hline & & & 67.5 & & 0.0004 \\
\hline & & & 90 & & -0.0001 \\
\hline & & & 112.5 & & -0.0006 \\
\hline & & & 135 & & -0.0007 \\
\hline & & & 157.5 & & -0.0004 \\
\hline & & & 180 & & 0.0001 \\
\hline & & & 125 & & -0.0007 \\
\hline & & & 35 & & 0.0007 \\
\hline \multirow{10}{*}{ Barú } & \multirow{10}{*}{334.59} & \multirow{10}{*}{-90} & 22.5 & \multirow{10}{*}{90} & -0.0006 \\
\hline & & & 45 & & -0.0004 \\
\hline & & & 67.5 & & -0.0003 \\
\hline & & & 90 & & -0.0003 \\
\hline & & & 112.5 & & -0.0004 \\
\hline & & & 135 & & -0.0006 \\
\hline & & & 157.5 & & -0.0007 \\
\hline & & & 180 & & -0.0007 \\
\hline & & & $\underline{125}$ & & -0.0005 \\
\hline & & & 35 & & -0.0005 \\
\hline \multirow{4}{*}{ San Cristóbal } & \multirow{4}{*}{343.24} & \multirow{4}{*}{-90} & 22.5 & \multirow{4}{*}{90} & 0.0004 \\
\hline & & & 45 & & 0.0005 \\
\hline & & & 67.5 & & 0.0002 \\
\hline & & & 90 & & -0.0002 \\
\hline
\end{tabular}




\begin{tabular}{|c|c|c|c|c|c|}
\hline & & & 112.5 & & -0.0005 \\
\hline & & & 135 & & -0.0006 \\
\hline & & & 157.5 & & -0.0003 \\
\hline & & & 180 & & 0.0001 \\
\hline & & & $\underline{125}$ & & -0.0006 \\
\hline & & & $\underline{35}$ & & $\underline{0.0005}$ \\
\hline \multirow{10}{*}{ Cosigüina } & \multirow{10}{*}{404.53} & \multirow{10}{*}{-90} & 22.5 & \multirow{10}{*}{90} & 0.0002 \\
\hline & & & 45 & & 0.0001 \\
\hline & & & 67.5 & & 0 \\
\hline & & & 90 & & -0.0002 \\
\hline & & & 112.5 & & -0.0003 \\
\hline & & & 135 & & -0.0003 \\
\hline & & & 157.5 & & -0.0002 \\
\hline & & & 180 & & 0 \\
\hline & & & 125 & & -0.0004 \\
\hline & & & 35 & & 0.0002 \\
\hline
\end{tabular}




\section{Appendix D}

Table D.1 - Strike values and their number of appearances as strike of max negative and positive change in normal stress.

\begin{tabular}{|c|c|c|c|}
\hline $\begin{array}{l}\text { Strik } \\
\text { e } \\
\text { valu } \\
\text { es }\end{array}$ & $\begin{array}{c}\text { \#appearances as strike of } \\
\text { Max POSITIVE (clamping) } \\
\text { stress change }\end{array}$ & $\begin{array}{l}\text { \#appearances as strike of } \\
\text { Max NEGATIVE } \\
\text { (unclamping) stress change }\end{array}$ & Note \\
\hline 22.5 & 1 & 3 & \\
\hline 45 & 0 & 11 & $\begin{array}{c}\text { Strike almost } \\
\text { orthogonal to } \\
\text { M.A.Trench strike }\end{array}$ \\
\hline 67.5 & 0 & 3 & \\
\hline 90 & 1 & 3 & \\
\hline $\begin{array}{c}112 . \\
5\end{array}$ & 2 & 1 & \\
\hline 135 & 10 & 0 & $\begin{array}{l}\text { Strike almost } \\
\text { parallel to } \\
\text { M.A.Trench strike }\end{array}$ \\
\hline $\begin{array}{c}157 . \\
5\end{array}$ & 4 & 1 & \\
\hline 180 & 3 & 1 & \\
\hline 125 & $\underline{8}$ & 1 & $\begin{array}{l}\text { Strike Parallel to } \\
\text { M.A.Trench strike }\end{array}$ \\
\hline 35 & 1 & $\underline{5}$ & $\begin{array}{l}\text { Strike Orthogonal } \\
\text { to M.A.Trench } \\
\text { strike }\end{array}$ \\
\hline
\end{tabular}




\section{Appendix E}

Table E.1 - Results from the dynamic stress change analysis. The data is obtained from synthetic seismograms computed with the single point source model.

\begin{tabular}{|c|c|c|c|c|c|c|c|c|c|c|c|}
\hline \multirow[b]{2}{*}{$\begin{array}{l}\text { Volc } \\
\text { ano }\end{array}$} & \multirow[b]{2}{*}{$\begin{array}{c}\text { Di } \\
\text { st } \\
\mathrm{a} \\
\mathrm{n} \\
\mathrm{c} \\
\mathrm{e} \\
\text { (k } \\
\mathrm{m} \\
\text { ) }\end{array}$} & \multicolumn{5}{|c|}{ Radial comp } & \multicolumn{5}{|c|}{ Tangential comp } \\
\hline & & $\begin{array}{l}\text { Peak to } \\
\text { peak } \\
\text { amplitu } \\
\text { de } \\
{[\mathrm{cm} / \mathrm{s}]}\end{array}$ & $\begin{array}{c}\text { Peak } \\
\text { dynam } \\
\text { ic } \\
\text { stress } \\
\text { [Mpa] }\end{array}$ & $\begin{array}{c}\text { Peak } \\
\text { freq } \\
\text { uenc } \\
y \\
{[\mathrm{~Hz}]}\end{array}$ & $\begin{array}{l}\text { P } \\
\text { er } \\
\text { io } \\
d \\
{[s} \\
]\end{array}$ & $\begin{array}{c}\text { Peak } \\
\text { frequen } \\
\text { cy } \\
\text { amplitu } \\
\text { de } \\
{[\mathrm{cm} / \mathrm{s}]}\end{array}$ & $\begin{array}{c}\text { Peak to } \\
\text { peak } \\
\text { amplitu } \\
\text { de } \\
{[\mathrm{cm} / \mathrm{s}]}\end{array}$ & $\begin{array}{c}\text { Peak } \\
\text { dynam } \\
\text { ic } \\
\text { stress } \\
\text { [Mpa] }\end{array}$ & $\begin{array}{c}\text { Peak } \\
\text { freq } \\
\text { uenc } \\
y \\
{[\mathrm{~Hz}]}\end{array}$ & $\begin{array}{l}P \\
\text { er } \\
\text { io } \\
d \\
{[s} \\
]\end{array}$ & $\begin{array}{c}\text { Peak } \\
\text { frequen } \\
\text { cy } \\
\text { amplitu } \\
\text { de } \\
{[\mathrm{cm} / \mathrm{s}]}\end{array}$ \\
\hline $\begin{array}{l}\text { Ten } \\
\text { orio }\end{array}$ & $\begin{array}{l}7 \\
2\end{array}$ & 4.40 & 0.440 & 0.04 & $\begin{array}{l}2 \\
5\end{array}$ & 37.5 & 2.50 & 0.250 & 0.03 & $\begin{array}{l}3 \\
3\end{array}$ & 21.2 \\
\hline $\begin{array}{c}\text { Mir } \\
\text { avall } \\
\text { es }\end{array}$ & $\begin{array}{l}7 \\
5\end{array}$ & 4.81 & 0.481 & 0.03 & $\begin{array}{l}3 \\
3\end{array}$ & 41.9 & 2.01 & 0.201 & 0.03 & $\begin{array}{l}3 \\
3\end{array}$ & 15.4 \\
\hline $\begin{array}{l}\text { Are } \\
\text { nal }\end{array}$ & $\begin{array}{l}7 \\
8\end{array}$ & 3.35 & 0.335 & 0.03 & $\begin{array}{l}3 \\
3\end{array}$ & 28.8 & 3.57 & 0.357 & 0.03 & $\begin{array}{l}3 \\
3\end{array}$ & 32.5 \\
\hline $\begin{array}{c}\text { Rinc } \\
\text { on } \\
\text { de } \\
\text { la } \\
\text { Veja }\end{array}$ & $\begin{array}{l}8 \\
2\end{array}$ & 4.62 & 0.462 & 0.03 & $\begin{array}{l}3 \\
3\end{array}$ & 41.0 & 2.63 & 0.263 & 0.03 & $\begin{array}{l}3 \\
3\end{array}$ & 19.1 \\
\hline $\begin{array}{c}\text { Oro } \\
\text { si }\end{array}$ & $\begin{array}{l}1 \\
0 \\
0\end{array}$ & 3.83 & 0.383 & 0.03 & $\begin{array}{l}3 \\
3\end{array}$ & 35.6 & 2.39 & 0.239 & 0.03 & $\begin{array}{l}3 \\
3\end{array}$ & 19.1 \\
\hline $\begin{array}{l}\text { Plat } \\
\text { anar }\end{array}$ & $\begin{array}{l}1 \\
0 \\
5\end{array}$ & 2.78 & 0.278 & 0.02 & $\begin{array}{l}5 \\
0\end{array}$ & 25.7 & 2.31 & 0.231 & 0.03 & $\begin{array}{l}3 \\
3\end{array}$ & 21.9 \\
\hline $\begin{array}{c}\text { Poa } \\
\text { S }\end{array}$ & $\begin{array}{l}1 \\
1 \\
8\end{array}$ & 2.33 & 0.233 & 0.02 & $\begin{array}{l}5 \\
0\end{array}$ & 22.3 & 1.73 & 0.173 & 0.03 & $\begin{array}{l}3 \\
3\end{array}$ & 16.7 \\
\hline $\begin{array}{c}\text { Barv } \\
\text { a }\end{array}$ & $\begin{array}{l}1 \\
3 \\
2\end{array}$ & 1.92 & 0.192 & 0.02 & $\begin{array}{l}5 \\
0\end{array}$ & 18.7 & 1.34 & 0.134 & 0.03 & $\begin{array}{l}3 \\
3\end{array}$ & 13.4 \\
\hline $\begin{array}{l}\text { Mad } \\
\text { eras }\end{array}$ & $\begin{array}{l}1 \\
5 \\
2\end{array}$ & 2.11 & 0.211 & 0.03 & $\begin{array}{l}3 \\
3\end{array}$ & 23.3 & 1.36 & 0.136 & 0.03 & $\begin{array}{l}3 \\
3\end{array}$ & 10.9 \\
\hline
\end{tabular}




\begin{tabular}{|c|c|c|c|c|c|c|c|c|c|c|c|}
\hline $\begin{array}{c}\text { Iraz } \\
u^{\prime}\end{array}$ & $\begin{array}{l}1 \\
5 \\
9\end{array}$ & 1.61 & 0.161 & 0.02 & $\begin{array}{l}5 \\
0\end{array}$ & 13.1 & 0.74 & 0.074 & 0.03 & $\begin{array}{l}3 \\
3\end{array}$ & 7.8 \\
\hline $\begin{array}{c}\text { Con } \\
\text { cepc } \\
\text { ion }\end{array}$ & $\begin{array}{l}1 \\
6 \\
4 \\
\end{array}$ & 1.78 & 0.178 & 0.03 & $\begin{array}{l}3 \\
3\end{array}$ & 19.2 & 1.33 & 0.133 & 0.03 & $\begin{array}{l}3 \\
3\end{array}$ & 11.2 \\
\hline $\begin{array}{c}\text { Turr } \\
\text { ialb } \\
\text { a }\end{array}$ & $\begin{array}{l}1 \\
6 \\
8\end{array}$ & 1.54 & 0.154 & 0.03 & $\begin{array}{l}3 \\
3\end{array}$ & 12.4 & 0.68 & 0.068 & 0.03 & $\begin{array}{l}3 \\
3\end{array}$ & 7.8 \\
\hline $\begin{array}{c}\text { Zap } \\
\text { ater } \\
\text { a }\end{array}$ & $\begin{array}{l}1 \\
9 \\
0\end{array}$ & 1.53 & 0.153 & 0.02 & $\begin{array}{l}5 \\
0\end{array}$ & 13.4 & 1.20 & 0.120 & 0.03 & $\begin{array}{l}3 \\
3\end{array}$ & 11.1 \\
\hline $\begin{array}{l}\text { Mo } \\
\text { mba } \\
\text { cho }\end{array}$ & $\begin{array}{l}2 \\
0 \\
5\end{array}$ & 1.43 & 0.143 & 0.04 & $\begin{array}{l}2 \\
5\end{array}$ & 12.1 & 1.17 & 0.117 & 0.03 & $\begin{array}{l}3 \\
3\end{array}$ & 11.0 \\
\hline $\begin{array}{c}\text { Gra } \\
\text { nad } \\
\text { a }\end{array}$ & $\begin{array}{l}2 \\
1 \\
6 \\
\end{array}$ & 1.42 & 0.142 & 0.04 & $\begin{array}{l}2 \\
5\end{array}$ & 13.0 & 1.13 & 0.113 & 0.03 & $\begin{array}{l}3 \\
3\end{array}$ & 10.4 \\
\hline $\begin{array}{c}\text { Mas } \\
\text { aya }\end{array}$ & $\begin{array}{l}2 \\
2 \\
9\end{array}$ & 1.30 & 0.130 & 0.04 & $\begin{array}{l}2 \\
5\end{array}$ & 11.2 & 1.10 & 0.110 & 0.04 & $\begin{array}{l}2 \\
5\end{array}$ & 9.8 \\
\hline $\begin{array}{c}\text { Neja } \\
\text { pa- } \\
\text { Mir } \\
\text { aflo } \\
\text { res } \\
\end{array}$ & $\begin{array}{l}2 \\
5 \\
0\end{array}$ & 1.25 & 0.125 & 0.04 & $\begin{array}{l}2 \\
5\end{array}$ & 13.0 & 1.17 & 0.117 & 0.03 & $\begin{array}{l}3 \\
3\end{array}$ & 8.8 \\
\hline $\begin{array}{c}\text { Apo } \\
\text { yeq } \\
\text { ue }\end{array}$ & $\begin{array}{l}2 \\
6 \\
4 \\
\end{array}$ & 1.26 & 0.126 & 0.04 & $\begin{array}{l}2 \\
5\end{array}$ & 13.6 & 1.12 & 0.112 & 0.04 & $\begin{array}{l}2 \\
5\end{array}$ & 8.2 \\
\hline $\begin{array}{c}\text { Mo } \\
\text { mot } \\
\text { omb } \\
o\end{array}$ & $\begin{array}{l}2 \\
9 \\
0\end{array}$ & 1.18 & 0.118 & 0.04 & $\begin{array}{l}2 \\
5\end{array}$ & 13.2 & 1.05 & 0.105 & 0.04 & $\begin{array}{l}2 \\
5\end{array}$ & 9.2 \\
\hline $\begin{array}{c}\text { Las } \\
\text { Pilas }\end{array}$ & $\begin{array}{l}3 \\
0 \\
6 \\
\end{array}$ & 1.13 & 0.113 & 0.04 & $\begin{array}{l}2 \\
5\end{array}$ & 12.4 & 1.01 & 0.101 & 0.04 & $\begin{array}{l}2 \\
5\end{array}$ & 9.7 \\
\hline $\begin{array}{c}\text { Cerr } \\
\text { o } \\
\text { Neg } \\
\text { ro }\end{array}$ & $\begin{array}{l}3 \\
0 \\
7\end{array}$ & 1.13 & 0.113 & 0.04 & $\begin{array}{l}2 \\
5\end{array}$ & 12.3 & 1.00 & 0.100 & 0.04 & $\begin{array}{l}2 \\
5\end{array}$ & 9.8 \\
\hline
\end{tabular}




\begin{tabular}{|c|c|c|c|c|c|c|c|c|c|c|c|}
\hline $\begin{array}{l}\text { Volc } \\
\text { an } \\
\text { Azul }\end{array}$ & $\begin{array}{l}3 \\
1 \\
1\end{array}$ & 1.17 & 0.117 & 0.04 & $\begin{array}{l}2 \\
5\end{array}$ & 14.9 & 0.87 & 0.087 & 0.04 & $\begin{array}{l}2 \\
5\end{array}$ & 11.2 \\
\hline Rota & $\begin{array}{l}3 \\
1 \\
4\end{array}$ & 1.12 & 0.112 & 0.04 & $\begin{array}{l}2 \\
5\end{array}$ & 12.1 & 0.96 & 0.096 & 0.04 & $\begin{array}{l}2 \\
5\end{array}$ & 10.0 \\
\hline $\begin{array}{c}\text { Telic } \\
\text { a }\end{array}$ & $\begin{array}{l}3 \\
2 \\
4\end{array}$ & 1.09 & 0.109 & 0.04 & $\begin{array}{l}2 \\
5\end{array}$ & 11.7 & 0.93 & 0.093 & 0.04 & $\begin{array}{l}2 \\
5\end{array}$ & 10.1 \\
\hline $\begin{array}{c}\text { Bar } \\
\text { u' }^{\prime}\end{array}$ & $\begin{array}{l}3 \\
3 \\
5\end{array}$ & 1.09 & 0.109 & 0.03 & $\begin{array}{l}3 \\
3\end{array}$ & 11.0 & 0.24 & 0.024 & 0.02 & $\begin{array}{l}5 \\
0\end{array}$ & 2.6 \\
\hline $\begin{array}{l}\text { San } \\
\text { Crist } \\
\text { obal }\end{array}$ & $\begin{array}{l}3 \\
4 \\
3\end{array}$ & 1.05 & 0.105 & 0.03 & $\begin{array}{l}3 \\
3\end{array}$ & 11.0 & 1.12 & 0.112 & 0.03 & $\begin{array}{l}3 \\
3\end{array}$ & 10.1 \\
\hline $\begin{array}{c}\text { Cosi } \\
\text { guin } \\
\text { a }\end{array}$ & $\begin{array}{l}4 \\
0 \\
5\end{array}$ & 0.96 & 0.096 & 0.04 & $\begin{array}{l}2 \\
5\end{array}$ & 9.3 & 0.65 & 0.065 & 0.03 & $\begin{array}{l}3 \\
3\end{array}$ & 9.7 \\
\hline
\end{tabular}




\section{Appendix F}

Table F.1 - Results from the dynamic stress change analysis. The data is obtained from synthetic seismograms computed with the finite fault model. These eight volcanoes showed signs of activity following the earthquake.

\begin{tabular}{|c|c|c|c|c|c|c|c|c|c|c|c|}
\hline \multirow[b]{2}{*}{ Volcano } & \multirow[b]{2}{*}{$\begin{array}{l}\text { Dist } \\
\text { ance } \\
(\mathrm{km})\end{array}$} & \multicolumn{5}{|c|}{ Radial comp - Rayleigh waves } & \multicolumn{5}{|c|}{ Tangential comp - Love waves } \\
\hline & & $\begin{array}{c}\text { Peak } \\
\text { to } \\
\text { peak } \\
\text { ampli } \\
\text { tude } \\
{[\mathrm{cm} / \mathrm{s}} \\
\text { ] }\end{array}$ & $\begin{array}{c}\text { Peak } \\
\text { dyna } \\
\text { mic } \\
\text { stres } \\
\text { s } \\
{[\mathrm{Mp}} \\
\text { a] }\end{array}$ & $\begin{array}{l}\text { Peak } \\
\text { frequ } \\
\text { ency } \\
{[\mathrm{Hz}]}\end{array}$ & $\begin{array}{l}\text { Per } \\
\text { iod } \\
{[s]}\end{array}$ & $\begin{array}{c}\text { Peak } \\
\text { frequ } \\
\text { ency } \\
\text { ampli } \\
\text { tude } \\
{[\mathrm{cm} / \mathrm{s}} \\
]\end{array}$ & $\begin{array}{c}\text { Peak } \\
\text { to } \\
\text { peak } \\
\text { ampli } \\
\text { tude } \\
{[\mathrm{cm} / \mathrm{s}} \\
\text { ] }\end{array}$ & $\begin{array}{c}\text { Peak } \\
\text { dyna } \\
\text { mic } \\
\text { stres } \\
\text { s } \\
\text { [Mp } \\
\text { a] }\end{array}$ & $\begin{array}{l}\text { Peak } \\
\text { frequ } \\
\text { ency } \\
{[\mathrm{Hz}]}\end{array}$ & $\begin{array}{l}\text { Per } \\
\text { iod } \\
{[s]}\end{array}$ & $\begin{array}{c}\text { Peak } \\
\text { frequ } \\
\text { ency } \\
\text { ampli } \\
\text { tude } \\
{[\mathrm{cm} / \mathrm{s}} \\
]\end{array}$ \\
\hline Arenal & 78 & 4.31 & $\begin{array}{c}0.43 \\
1\end{array}$ & 0.28 & 4 & 47.7 & 3.68 & $\begin{array}{c}0.36 \\
8\end{array}$ & 0.05 & 20 & 85.0 \\
\hline $\begin{array}{c}\text { Rincon de } \\
\text { la Vieja }\end{array}$ & 82 & 2.87 & $\begin{array}{c}0.28 \\
7 \\
\end{array}$ & 0.04 & 23 & 74.5 & 3.43 & $\begin{array}{c}0.34 \\
3 \\
\end{array}$ & 0.05 & 22 & 72.5 \\
\hline Poas & 118 & 3.10 & $\begin{array}{c}0.31 \\
0\end{array}$ & 0.04 & 23 & 68.7 & 3.01 & $\begin{array}{c}0.30 \\
1\end{array}$ & 0.03 & 34 & 51.5 \\
\hline Turrialba & 168 & 1.73 & $\begin{array}{c}0.17 \\
3\end{array}$ & 0.04 & 26 & 32.2 & 1.31 & $\begin{array}{c}0.13 \\
1\end{array}$ & 0.04 & 26 & 31.8 \\
\hline Apoyeque & 264 & 1.23 & $\begin{array}{c}0.12 \\
3\end{array}$ & 0.05 & 22 & 41.6 & 1.39 & $\begin{array}{c}0.13 \\
9\end{array}$ & 0.05 & 21 & 19.5 \\
\hline $\begin{array}{l}\text { Cerro } \\
\text { Negro }\end{array}$ & 307 & 0.88 & $\begin{array}{c}0.08 \\
8\end{array}$ & 0.04 & 24 & 34.6 & 0.93 & $\begin{array}{c}0.09 \\
3\end{array}$ & 0.04 & 23 & 20.6 \\
\hline Telica & 324 & 0.73 & $\begin{array}{c}0.07 \\
3 \\
\end{array}$ & 0.04 & 24 & 32.6 & 0.77 & $\begin{array}{c}0.07 \\
7 \\
\end{array}$ & 0.04 & 25 & 18.9 \\
\hline $\begin{array}{c}\text { San } \\
\text { Cristobal }\end{array}$ & 343 & 0.68 & $\begin{array}{c}0.06 \\
8\end{array}$ & 0.04 & 26 & 28.5 & 0.60 & $\begin{array}{c}0.06 \\
0\end{array}$ & 0.04 & 26 & 21.0 \\
\hline
\end{tabular}




\section{Appendix G}

Table G.1 - Parameters used in the statistical analysis.

\begin{tabular}{|c|c|c|c|c|c|c|c|c|c|}
\hline \multicolumn{2}{|c|}{ San Cristobal } & \multicolumn{2}{|c|}{ Poas } & \multicolumn{2}{|c|}{ Telica } & \multicolumn{2}{|c|}{ Conception } & \multicolumn{2}{|c|}{ Masaya } \\
\hline $\begin{array}{c}\text { Date of } \\
\text { eruptio } \\
\qquad n \\
(\mathrm{~d} / \mathrm{m} / \mathrm{y} \\
\quad)\end{array}$ & $\begin{array}{c}\text { Days } \\
\text { betwee } \\
n 2 \\
\text { followin } \\
\text { g } \\
\text { events }\end{array}$ & $\begin{array}{c}\text { Date of } \\
\text { eruptio } \\
n \\
(\mathrm{~d} / \mathrm{m} / \mathrm{y} \\
)\end{array}$ & $\begin{array}{c}\text { Days } \\
\text { betwee } \\
\mathrm{n} 2 \\
\text { followin } \\
\mathrm{g} \\
\text { events }\end{array}$ & $\begin{array}{c}\text { Date of } \\
\text { eruptio } \\
n \\
(\mathrm{~d} / \mathrm{m} / \mathrm{y} \\
\quad)\end{array}$ & $\begin{array}{c}\text { Days } \\
\text { betwee } \\
\text { n } 2 \\
\text { followin } \\
\text { g } \\
\text { events }\end{array}$ & $\begin{array}{c}\text { Date of } \\
\text { eruptio } \\
n \\
(\mathrm{~d} / \mathrm{m} / \mathrm{y} \\
)\end{array}$ & \begin{tabular}{|} 
Days \\
betwee \\
$\mathrm{n} 2$ \\
followin \\
$\mathrm{g}$ \\
events
\end{tabular} & $\begin{array}{c}\text { Date of } \\
\text { eruptio } \\
n \\
(d / \mathrm{m} / \mathrm{y} \\
)\end{array}$ & $\begin{array}{c}\text { Days } \\
\text { betwee } \\
\mathrm{n} 2 \\
\text { followin } \\
\mathrm{g} \\
\text { events }\end{array}$ \\
\hline $\begin{array}{c}21 / 6 / 0 \\
1\end{array}$ & & $\begin{array}{c}24 / 3 / 0 \\
6\end{array}$ & & $\begin{array}{c}9 / 1 / 0 \\
7\end{array}$ & & $\begin{array}{c}28 / 7 / 0 \\
5\end{array}$ & & $\begin{array}{c}23 / 04 / \\
2001\end{array}$ & \\
\hline $6 / 3 / 06$ & 1719 & $\begin{array}{c}26 / 9 / 0 \\
6 \\
\end{array}$ & 186 & $\begin{array}{c}15 / 2 / \\
07 \\
\end{array}$ & 37 & $\begin{array}{c}29 / 7 / 0 \\
5\end{array}$ & 1 & $\begin{array}{c}24 / 04 / \\
2001 \\
\end{array}$ & 1 \\
\hline $\begin{array}{c}26 / 4 / 0 \\
6\end{array}$ & 51 & $\begin{array}{c}25 / 10 / \\
06\end{array}$ & 29 & $\begin{array}{c}14 / 5 / \\
11\end{array}$ & 1549 & $7 / 2 / 07$ & 558 & $\begin{array}{c}25 / 04 / \\
2001\end{array}$ & 1 \\
\hline $\begin{array}{c}22 / 6 / 0 \\
8\end{array}$ & 788 & $\begin{array}{c}13 / 1 / 0 \\
8\end{array}$ & 445 & $\begin{array}{c}18 / 5 / \\
11\end{array}$ & 4 & $\begin{array}{c}10 / 2 / 0 \\
7\end{array}$ & 3 & $\begin{array}{c}23 / 05 / \\
2001\end{array}$ & 28 \\
\hline $\begin{array}{c}11 / 7 / 0 \\
8\end{array}$ & 19 & $\begin{array}{c}25 / 12 / \\
09\end{array}$ & 712 & $\begin{array}{c}20 / 5 / \\
11\end{array}$ & 2 & $8 / 4 / 07$ & 57 & $\begin{array}{c}18 / 06 / \\
2008\end{array}$ & 2583 \\
\hline $\begin{array}{c}19 / 11 / \\
08\end{array}$ & 131 & $\begin{array}{c}23 / 2 / 1 \\
0\end{array}$ & 60 & $\begin{array}{c}11 / 9 / \\
12\end{array}$ & 480 & $\begin{array}{c}22 / 4 / 0 \\
7\end{array}$ & 14 & & \\
\hline 2/9/09 & 287 & $\begin{array}{c}15 / 9 / 1 \\
0\end{array}$ & 204 & & & $\begin{array}{c}10 / 7 / 0 \\
7\end{array}$ & 79 & & \\
\hline $8 / 9 / 12$ & 1102 & $\begin{array}{c}15 / 11 / \\
10\end{array}$ & 61 & & & $\begin{array}{c}20 / 12 / \\
07\end{array}$ & 163 & & \\
\hline $\begin{array}{c}11 / 9 / 1 \\
2\end{array}$ & 3 & $2 / 2 / 11$ & 79 & & & $\begin{array}{c}11 / 12 / \\
09\end{array}$ & 722 & & \\
\hline $\begin{array}{c}25 / 12 / \\
12\end{array}$ & 105 & $\begin{array}{c}15 / 4 / 1 \\
1\end{array}$ & 72 & & & $\begin{array}{c}12 / 3 / 1 \\
0\end{array}$ & 91 & & \\
\hline $\begin{array}{c}26 / 12 / \\
12\end{array}$ & 1 & $\begin{array}{c}25 / 5 / 1 \\
1\end{array}$ & 40 & & & & & & \\
\hline \multirow[t]{6}{*}{$7 / 6 / 13$} & 163 & $6 / 5 / 12$ & 347 & & & & & & \\
\hline & & $\begin{array}{c}15 / 5 / 1 \\
2\end{array}$ & 9 & & & & & & \\
\hline & & $\begin{array}{c}20 / 5 / 1 \\
2\end{array}$ & 5 & & & & & & \\
\hline & & $\begin{array}{c}26 / 5 / 1 \\
2\end{array}$ & 6 & & & & & & \\
\hline & & $\begin{array}{c}27 / 10 / \\
12\end{array}$ & 154 & & & & & & \\
\hline & & $28 / 10 /$ & 1 & & & & & & \\
\hline
\end{tabular}




\begin{tabular}{|c|c|c|c|c|c|c|c|c|c|}
\hline & & 12 & & & & & & & \\
\hline & & $1 / 5 / 13$ & 185 & & & & & & \\
\hline & & $\begin{array}{c}28 / 5 / 1 \\
3\end{array}$ & 27 & & & & & & \\
\hline & & $\begin{array}{c}25 / 2 / 1 \\
4\end{array}$ & 273 & & & & & & \\
\hline & & $\begin{array}{c}30 / 3 / 1 \\
4\end{array}$ & 33 & & & & & & \\
\hline \multicolumn{2}{|c|}{ San Cristobal } & \multicolumn{2}{|c|}{ Poas } & \multicolumn{2}{|c|}{ Telica } & \multicolumn{2}{|c|}{ Conception } & \multicolumn{2}{|c|}{ Masaya } \\
\hline $\begin{array}{l}\text { Mean } \\
\text { recurre } \\
\text { nce } \\
\text { time } \\
\text { (years) }\end{array}$ & $\begin{array}{c}\text { Standar } \\
\mathrm{d} \\
\text { deviatio } \\
\mathrm{n} \\
\text { (years) }\end{array}$ & $\begin{array}{c}\text { Mean } \\
\text { recurre } \\
\text { nce } \\
\text { time } \\
\text { (years) }\end{array}$ & $\begin{array}{c}\text { Standar } \\
\mathrm{d} \\
\text { deviatio } \\
\mathrm{n} \\
\text { (years) }\end{array}$ & $\begin{array}{c}\text { Mean } \\
\text { recurre } \\
\text { nce } \\
\text { time } \\
\text { (years) }\end{array}$ & $\begin{array}{c}\text { Standar } \\
\mathrm{d} \\
\text { deviatio } \\
\mathrm{n} \\
\text { (years) }\end{array}$ & \begin{tabular}{|c|} 
Mean \\
recurre \\
nce \\
time \\
(years)
\end{tabular} & $\begin{array}{c}\text { Standar } \\
\mathrm{d} \\
\text { deviatio } \\
\mathrm{n} \\
\text { (years) }\end{array}$ & $\begin{array}{c}\text { Mean } \\
\text { recurre } \\
\text { nce } \\
\text { time } \\
\text { (years) }\end{array}$ & $\begin{array}{c}\text { Standar } \\
\mathrm{d} \\
\text { deviatio } \\
\mathrm{n} \\
\text { (years) }\end{array}$ \\
\hline 1.09 & 1.55 & 0.40 & 0.50 & 1.13 & 1.82 & 0.51 & 0.72 & 1.79 & 3.52 \\
\hline
\end{tabular}




\section{Appendix H}

Credit and copyright policies of material used in this thesis:

Images from the USGS website:

http://www.usgs.gov/visual-id/credit_usgs.html

Images and maps from Google Earth Pro:

http://www.google.com/permissions/geoguidelines/attr-guide.html 